Synthesis of Geochronologic Research on Late Pliocene to Holocene Emergent Shorelines in the Lower Savannah River Area of Southeastern Georgia, USA

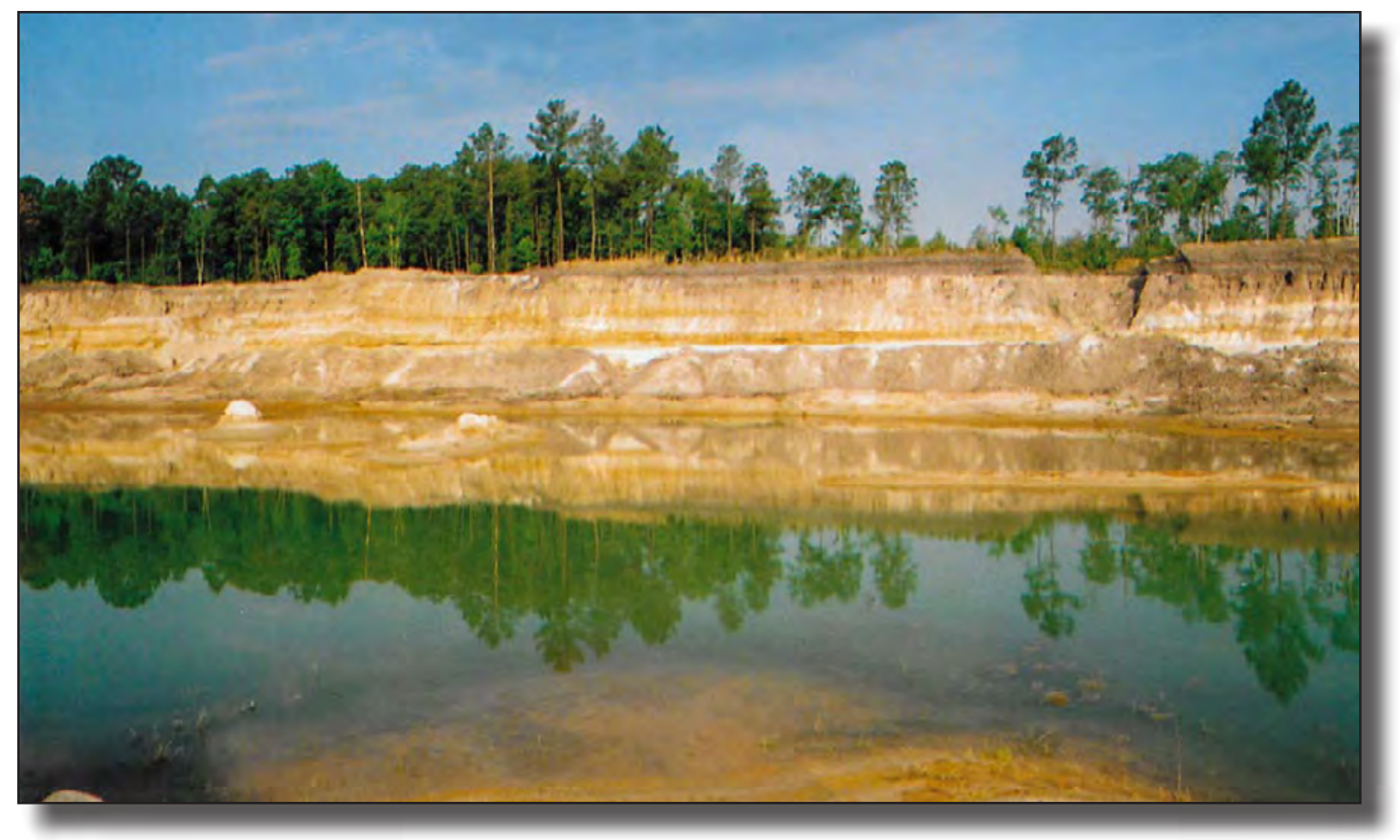

Open-File Report 2021-1015 
Cover. Borrow pit in the Pleistocene Pamlico Shoreline Complex in Chatham County, Georgia. Photograph taken by Helaine W. Markewich, U.S. Geological Survey. 


\section{Synthesis of Geochronologic Research on Late Pliocene to Holocene Emergent Shorelines in the Lower Savannah River Area of Southeastern Georgia, USA}

By Helaine W. Markewich, Milan J. Pavich, Shannon A. Mahan, Paul R. Bierman, Wilma B. Alemán-González, and Arthur P. Schultz

Open-File Report 2021-1015 


\section{U.S. Geological Survey, Reston, Virginia: 2021}

For more information on the USGS - the Federal source for science about the Earth, its natural and living resources, natural hazards, and the environment—visit https://www.usgs.gov or call 1-888-ASK-USGS.

For an overview of USGS information products, including maps, imagery, and publications, visit https://store.usgs.gov/.

Any use of trade, firm, or product names is for descriptive purposes only and does not imply endorsement by the U.S. Government.

Although this information product, for the most part, is in the public domain, it also may contain copyrighted materials as noted in the text. Permission to reproduce copyrighted items must be secured from the copyright owner.

Suggested citation:

Markewich, H.W., Pavich, M.J., Mahan, S.A., Bierman, P.A., Alemán-González, W.B., and Schultz, A.P., 2021, Synthesis of geochronologic research on Late Pliocene to Holocene emergent shorelines in the lower Savannah River area of southeastern Georgia, USA: U.S. Geological Survey Open-File Report 2021-1015, 48 p., https://doi.org/10.3133/ofr20211015.

ISSN 2331-1258 (online) 


\section{Acknowledgments}

Analytical data included in the tables and figures in this report are being published for the first time. Funding for the field work and for collection and analyses of laboratory samples was provided by the U.S. Geological Survey (USGS) National Cooperative Geologic Mapping Program and the USGS Climate and Land-Use Change Research and Development Program. We thank Chris W. Waters of Lanyard Development Inc., Pooler, Georgia, for access to company properties; Keith Johnson and James Long for access to the Springfield-Stillwell pit; and David Crawley and the Effingham County, Georgia, Board of Commissioners for access to county properties and right-of-way. Special thanks to Gene Cobbs and Jeff Grey, former USGS drill crew, for their help in acquiring new data; J.C. Jackson, USGS, for the clay mineral analyses; and G.R. Buell, USGS, for GIS assistance. We thank T.M. Cronin, USGS; W.R. Doar III, South Carolina Geological Survey; Ron Counts, Mississippi Mineral Resources Institute; and M.S. Harris, College of Charleston, for their thoughtful comments on the post-Miocene geology of the southeastern Atlantic Coastal Plain and the lower Savannah River area. We also thank Marci M. Robinson, USGS, and Christopher S. Swezey, USGS, for reviewing the manuscript. 



\section{Contents}

Acknowledgments ……...................................................................................................................

Abstract

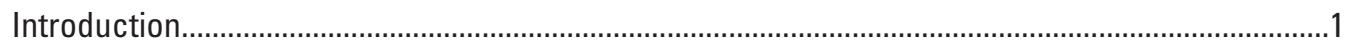

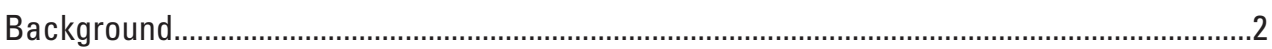

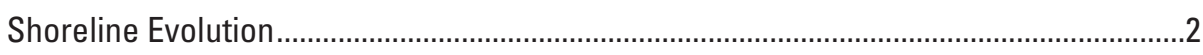

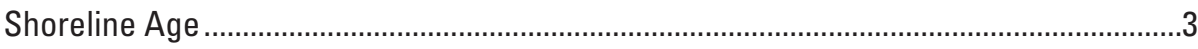

LSRA Shoreline Deposits and Shoreline Complexes_Stratigraphy and Age .................................9

Pliocene(?) or Older Deposits Atop and Landward of the Orangeburg Scarp ........................13

Late Pliocene and Early Pleistocene Deposits .........................................................................13

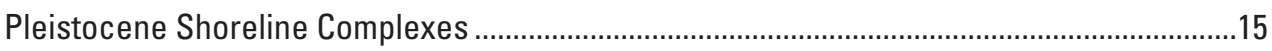

Wicomico Shoreline Complex (Qwi and Qwm) ............................................................16

Penholoway Shoreline Complex (Qpni and Qpnm) .........................................................16

Talbot Shoreline Complex (Qti and Qtm) ........................................................................16

Pamlico, Princess Anne, Silver Bluff and Holocene Shoreline Complexes......................16

Pamlico Shoreline Complex (Qpmi and Qpmm) ..................................................20

Princess Anne Shoreline Complex (Qpai and Qpam) ..............................................25

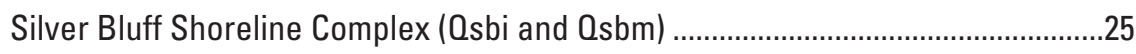

Holocene Shoreline Complex (Qhi and Qhm) ....................................................25

Details for Previously Unpublished Age and Stratigraphic Data.................................................25

Brooklet Auger Hole, Atop the Orangeburg Scarp ...........................................................28

Chimney Road Core, Penholoway Shoreline Complex ........................................................28

1716, Shuman, and Redgate Borrow Pits, Pamlico Shoreline Complex ..................................31

Localities Seaward of the Pamlico Shoreline Complex ……...................................................

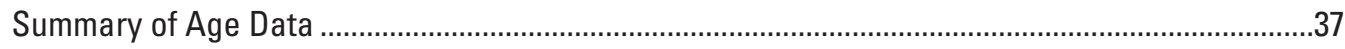

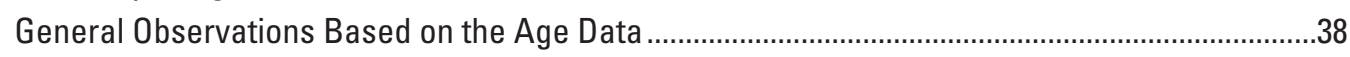

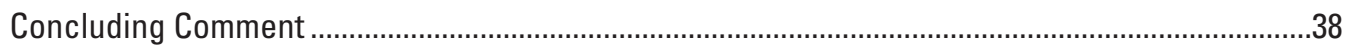

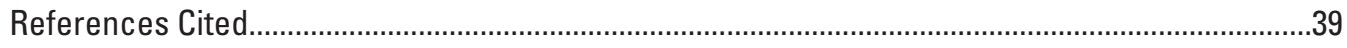

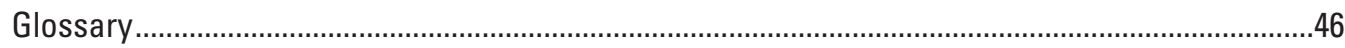

Appendix 1. Methods Used for Sampling and Analyses.........................................................47

\section{Figures}

1. Map of the eastern United States of America, a map of the southeastern United States showing physiographic provinces, and a latitudinal section

2. Maps showing political boundaries; geographic names; locations of described and sampled borrow pits, outcrops, and borings; and map units of Lawton and others (1976)

3. Age ranges and elevations for Pleistocene formations, shoreline sequences, and shoreline complexes

4. Lithostratigraphy and general pedologic description for the probable late Pliocene to earliest Pleistocene near-shore marine-sand at the top of the Orangeburg Scarp in Bulloch County, Georgia. 
5. Lithostratigraphy, general pedologic description, and optically stimulated luminescence age data for Penholoway barrier deposits and overlying eolian sand in Effingham County, Georgia

6. Lithostratigraphy, general pedologic description, and optically stimulated luminescence ages for Pamlico barrier deposits described and sampled in borrow pit exposures, Chatham County, Georgia.

7. Lithostratigraphy of the Chatham 1 core in Qpam deposits on Isle of Hope, Chatham County, Georgia..

8. Lithostratigraphy of the Chatham 18 core in 0sbi deposits, Skidaway Island, Chatham County, Georgia..

\section{Tables}

1. Published and previously unpublished age data for late Pleistocene and Holocene near-shore marine and estuarine deposits in the lower

Savannah River area, southeastern Georgia

2. Published and previously unpublished age data for late Pliocene to middle

Pleistocene near-shore marine and estuarine deposits in the lower

Savannah River area, southeastern Georgia

3. Previously unpublished quartz optically stimulated luminescence ages and data for samples from Chatham and Effingham counties, southeastern Georgia

4. Beryllium-10 concentration, horizon inventories, profile inventory, and minimum unit residence time, Brooklet auger hole, Bulloch County, Georgia.

5. Beryllium-10 concentration, horizon inventories, profile inventory, and minimum unit residence time, Chimney Road core, Effingham County, Georgia

6. Beryllium-10 concentration, horizon inventories, profile inventory, and minimum unit residence time, Shuman borrow pit, Chatham County, Georgia

7. Beryllium-10 concentration, horizon inventories, profile inventory, and minimum unit residence time, Redgate borrow pit, Chatham County, Georgia

8. Soil age indicator values for late Pliocene and Pleistocene emergent shoreline deposits in the lower Savannah River area, southeastern Georgia.

9. Particle-size distribution data in weight percent, Chimney Road core, Effingham County, Georgia

10. Major element oxide chemistry in weight percent, Chimney Road core, Effingham County, Georgia

11. Particle-size distribution data in weight percent, 1716 borrow pit, Chatham County, Georgia

12. Major element oxide chemistry in weight percent for samples from the $\mathbf{1 7 1 6}$ borrow pit, Chatham County, Georgia

13. Minor element chemistry in parts per million for samples from the $\mathbf{1 7 1 6}$ borrow pit, Chatham County, Georgia

14. Minor element chemistry in parts per million for samples from the $\mathbf{1 7 1 6}$ borrow pit, Chatham County, Georgia

15. Particle-size distribution data in weight percent, Shuman borrow pit, 
16. Particle-size distribution data in weight percent, Shuman borrow pit, Chatham County, Georgia...

17. Major element oxide chemistry in weight percent for samples from the Shuman borrow pit, Chatham County, Georgia

\section{Conversion Factors}

U.S. customary units to International System of Units

\begin{tabular}{lcll}
\hline & Multiply & By & To obtain \\
\hline \multicolumn{4}{c}{ Length } \\
\hline inch (in.) & 2.54 & centimeter (cm) \\
inch (in.) & 25.4 & millimeter (mm) \\
foot (ft) & 0.3048 & meter (m) & \\
\hline
\end{tabular}

International System of Units to U.S. customary units

\begin{tabular}{|c|c|c|}
\hline Multiply & By & To obtain \\
\hline \multicolumn{3}{|c|}{ Length } \\
\hline centimeter $(\mathrm{cm})$ & 0.3937 & inch (in.) \\
\hline millimeter (mm) & 0.03937 & inch (in.) \\
\hline meter (m) & 3.281 & foot (ft) \\
\hline kilometer (km) & 0.6214 & mile (mi) \\
\hline \multicolumn{3}{|c|}{ Area } \\
\hline square meter $\left(\mathrm{m}^{2}\right)$ & 10.76 & square foot $\left(\mathrm{ft}^{2}\right)$ \\
\hline
\end{tabular}

\section{Supplemental Information}

This report synthesizes published and previously unpublished age data for emergent late Pliocene to Holocene shoreline deposits in the lower Savannah River area (LSRA) of Georgia, a part of the southeastern Atlantic Coastal Plain (SEACP), and presents a preliminary chronology for these deposits based on included data. The cited references are only a fraction of the literature available on emergent shoreline deposits in the SEACP but provide a concise summary and present status of geologic investigations in the LSRA. Most previously unpublished data presented in this report are from investigations by the authors. Appendix 1 includes an explanation and a discussion of dating methods used to determine deposit age. The map coordinate system is the USA Contiguous Albers Equal Area Conic USGS version; the central meridian is $96^{\circ} \mathrm{W}$. The datum is North American Datum of 1983 (NAD83). 


\section{Abbreviations}

\begin{tabular}{|c|c|}
\hline $\mathrm{ACP}$ & Atlantic Coastal Plain \\
\hline AAR & amino acid racemization \\
\hline AMS & accelerator mass spectrometry \\
\hline${ }^{10 B e}$ & Beryllium-10 \\
\hline 10BePRT & Beryllium-10 paleosol residence time \\
\hline $\mathrm{cm}$ & centimeter \\
\hline $\mathrm{cm}^{2}$ & square centimeter \\
\hline $\mathrm{cm}^{3}$ & cubic centimeter \\
\hline${ }^{14} \mathrm{C}$ & carbon-14, radiocarbon \\
\hline DEM & digital elevation model \\
\hline $\mathrm{Fm}$ & Formation \\
\hline g & gram \\
\hline ka & age in thousands of years \\
\hline $\mathrm{kW} / \mathrm{m}^{2}$ & kilowatts per square meter \\
\hline lidar & light detection and ranging \\
\hline LSRA & lower Savannah River area \\
\hline $\mathrm{m}$ & meter \\
\hline $\mathrm{Ma}$ & age in millions of years \\
\hline OSL & optically stimulated luminescence \\
\hline $\mathrm{Pa}$ & protactinium \\
\hline ppm & parts per million \\
\hline SEACP & southeastern Atlantic Coastal Plain \\
\hline $\mathrm{Sr}$ & strontium \\
\hline Th & thorium \\
\hline $\mathrm{U}$ & uranium \\
\hline U-series & uranium disequilibrium series \\
\hline USA & United States of America \\
\hline USGS & U.S. Geological Survey \\
\hline yr & year \\
\hline
\end{tabular}




\title{
Synthesis of Geochronologic Research on Late Pliocene to Holocene Emergent Shorelines in the Lower Savannah River Area of Southeastern Georgia, USA
}

\author{
By Helaine W. Markewich,1 Milan J. Pavich,2 Shannon A. Mahan,1 Paul R. Bierman,3 \\ Wilma B. Alemán-González, ${ }^{1}$ and Arthur P. Schultz²
}

\section{Abstract}

Emergent late Pliocene and Pleistocene shoreline deposits, morphologically identifiable Pleistocene shoreline units, and seaward-facing scarps characterize the easternmost Atlantic Coastal Plain (ACP) of the United States of America. In some areas of the ACP, these deposits, units, and scarps have been studied in detail. Within these areas, temporal and spatial data are sufficient for time-depositional frameworks for shoreline-evolution to have been developed and published. For other areas, such as the southeastern Atlantic Coastal Plain (SEACP), available data are conflicting and (or) insufficient to develop such a framework, or to make shoreline correlations. Differential epeirogenic uplift and shoreline deformation, resulting from mantle-flow and climate-induced isostatic adjustments, complicate regional shoreline correlations. In the SEACP, the topographically prominent Orangeburg Scarp (hereafter, the Scarp) rises tens of meters in elevation from southeastern Georgia to southeastern North Carolina. The degree to which the Scarp and shoreline units seaward of the Scarp are deformed continues to be debated, but there is general agreement that the lower Savannah River area (LSRA) of Georgia and South Carolina is the least deformed area of the SEACP.

This paper synthesizes published and previously unpublished numerical age and stratigraphic data for emergent Pliocene and younger shoreline deposits in the LSRA in Georgia. Age data are applied to these shoreline deposits as they are delineated (map units) on the 1976 geologic map of Georgia by Lawton and others. Age assignments are based on stratigraphic position, fossil content, soil and weathering diagnostic properties, and numerical ages as determined by meteoric Beryllium-10 paleosol residence time ( $\left.{ }^{10} \mathrm{BePRT}\right)$, optically stimulated luminescence (OSL), uranium disequilibrium series (U-series), amino acid racemization (AAR), and radiocarbon $\left({ }^{14} \mathrm{C}\right)$ analyses. These data provide a preliminary

\footnotetext{
${ }^{1}$ U.S. Geological Survey.

2U.S. Geological Survey, retired.

${ }^{3}$ University of Vermont.
}

Pliocene-Pleistocene geochronology for the Orangeburg Scarp and shoreline deposits seaward of the Scarp in the LSRA of Georgia. Minimum ages and age ranges indicate the following:

- the Orangeburg Scarp formed sometime in the late Pliocene and early Pleistocene, between $3 \mathrm{Ma}$ and $1 \mathrm{Ma}$;

- three, and possibly four, shoreline complexes were deposited in the middle Pleistocene;

- two shoreline complexes were deposited in the late middle and the late Pleistocene;

- deposition of the youngest shoreline complex began in the late Pleistocene and continues to the present;

- each shoreline complex was modified by multiple sea level highstands over time periods that lasted tens of thousands to hundreds of thousands of years; and

- Pleistocene shoreline chronology differs in part from modeled global sea level highstands.

\section{Introduction}

The easternmost Atlantic Coastal Plain (ACP) of the United States of America from New Jersey to northeastern Florida is characterized by emergent Pliocene and Pleistocene barrier/beach-ridge and back-barrier deposits and prominent seaward-facing scarps. Many of the barrier/beach-ridge and back-barrier deposits form morphologically identifiable units that have been mapped as stratigraphic formations and (or) informally referred to as shoreline deposits, sequences, and complexes. These morphostratigraphic units, shoreline deposits with no apparent surface morphology, and scarps extend for tens to hundreds of kilometers subparallel to the present coast. Elevation change greater than a few meters along the length of a mappable shoreline unit, an individual barrier/beach-ridge, or a scarp has been attributed to broad wavelength, mantle-flow and climate induced, crustal deformation that occurred during and (or) after shoreline formation. The degree of deformation is not regionally uniform, continues to be debated, and complicates shoreline correlation. 
A number of references on the stratigraphy and degree of deformation of these shoreline units and scarps are included in the Background section of the Introduction. We refer the reader to articles in Oaks and DuBar (1974a) and the included references for a summary of ACP Pleistocene stratigraphic research through the middle 1970s. Since the late 1970s, most published spatial data (for example, geologic maps and elevation profiles), time-stratigraphic data, and numerical age data are for emergent shoreline units in the middle ACP north of the Cape Fear Arch and the southeastern ACP (SEACP), north of Charleston, South Carolina (fig. 1). Doar and Kendall (2014) provide references and a summary of stratigraphic research and a discussion on possible deformation of Pleistocene units and scarps in South Carolina. Their data, however, are limited for the area south of Charleston. This report focuses on presenting published and previously unpublished stratigraphic and age data for emergent Pliocene and Pleistocene shoreline units in the lower Savannah River area (LSRA) of Georgia (fig. 1). Most of the numerical ages are the result of investigations made in the last 30 years, and the preliminary shoreline chronology presented in this report is based on these data. Since the focus of this report is on shoreline unit age and not on stratigraphic interpretations, the terms in this report (such as deposit and sequence) are used as they were by the authors of the cited publications and are defined in the Glossary.

\section{Background}

\section{Shoreline Evolution}

Most studies of SEACP Pliocene and Pleistocene shoreline evolution have used the Orangeburg Scarp (hereafter, the Scarp) as a landward geographic limit of Pliocene sea level highstands. In the SEACP, the Scarp rises tens of meters in elevation from southeastern Georgia to southeastern North Carolina (figs. $1 C$ and $2 C$ ). The Scarp is considered to be the wave-cut erosional landward limit of Pliocene sea level highstands (for example, Doering, 1960; Winker and Howard, 1977; Blackwelder, 1981; Colquhoun, 1988; Huddlestun, 1988; Dowsett and Cronin, 1990; Colquhoun and others, 1991). Discontinuous morphologically indistinct, near-surface late Pliocene and early Pleistocene deposits occur just seaward of the Scarp. Morphologically distinct Pleistocene deposits occur seaward of, and commonly overlie, the late Pliocene and early Pleistocene deposits. These younger deposits are expressed as combinations of linear barrier/beach-ridges, cuspate barrier ridges, drumstick-shaped barriers, or nearly planar back-barrier marshes and swamps. Models to explain the configuration, elevation, and age of emergent shoreline deposits, sequences, and scarps in the SEACP continue to evolve. Most models include the development of marine terraces that are genetically linked to underlying deposits. References for the development of evolutionary models for emergent Pliocene and Pleistocene shorelines in the LSRA are included in the following paragraphs. Some of these models include the role of late Cenozoic crustal movement in syndepositional and postdepositional shoreline deformation. Models that include the role of crustal movement in shoreline configuration indicate that the lower Savannah
River area (LSRA, fig. 1A, $B$ ) of Georgia and South Carolina is the least deformed part of the SEACP (Winker and Howard, 1977; Blackwelder, 1981; Cronin and others, 1981; Dowsett and Cronin, 1990; Rowley and others, 2013; Rovere and others, 2014, 2015).

The reader is referred to the introduction in Herrick (1965) for a succinct summary of Pliocene and Pleistocene deposits and shoreline studies in southeastern Georgia to that date. Herrick (1965) referenced models for Pleistocene shoreline evolution as presented by Veatch and Stephenson (1911) and Cooke (1925; 1930a,b; 1931; 1943). Those investigators identified numerous terraces in the Georgia Coastal Plain and considered each terrace to represent a shoreline and to be a unique formation. They disagreed only in the number of shorelines/formations. Cooke (1943) identified eight shorelines/formations in Georgia and considered the so-called terrace surface of each formation to be a former sea floor. Herrick $(1965$, p. 2$)$ disagreed and considered Pleistocene deposits in Georgia to be a "...simple, wedgeshaped, stratified mass which constitutes a single lithologic unit upon which physiographic forms have been superimposed." Herrick (1965, p. 7) considered the relatively flat terrace surfaces and their associated scarps to be the result of “.... cutting and redeposition during successive retreats and lower stands of the sea." This controversy was between two differing concepts of emergent Pleistocene shoreline evolution: (1) that each terrace, underlying strata, and associated scarp comprises a unique morphostratigraphic formation; and (2) that the terraces are physiographic forms that are superposed on only one lithostratigraphic formation. The controversy continued with the work of Hoyt and Hails $(1967,1974)$, Hails and Hoyt (1969), Winker and Howard (1977), and Huddlestun (1988). Hoyt and Hails (1967) generally agreed with the model of Cooke (1943) and described each formation as occurring seaward of and truncating older topographically higher shoreline formations. They identified six major Pleistocene shoreline formations in Georgia, each with a barrier island and lagoonal-marsh facies (fig. 2A-D). Neither Cooke (1943) nor Hoyt and Hails (1967) considered the shorelines to be deformed. The shoreline model of Hoyt and Hails (1967) was adopted by Lawton and others (1976) for Pleistocene map units on their geologic map of Georgia. For the map, they used the term "shoreline complex" for each shoreline formation (fig. 2A-D). Winker and Howard (1977) disagreed with the models of Cooke (1943), Herrick (1965), and Hoyt and Hails (1967). Winker and Howard (1977, p. 124 and caption for fig. 2) stated that their "New paleogeographic reconstructions led to new correlations of shallow stratigraphic units previously described from detailed local studies." They referred to these units as "shoreline sequences,"4 and traced each shoreline sequence from northeastern Florida

\footnotetext{
4Winker and Howard (1977, p. 123 and 124) differentiated what they called "the shoreline record" into "regressive shoreline sequences" on the basis of three "form(s) of evidence." Their "primary basis for correlation" were regional progradational discontinuities that they considered "analogous to regional unconformities in stratigraphy." Their second "form of evidence" was the degree of preservation of depositional surfaces that they interpreted as changing at each progradational discontinuity. Their third "line of evidence" was a change in coastal morphology that they interpreted as a "change in the style of beachridge progradation." They named three "especially well preserved" sequences (figs. $1 B$ and 3 in this report).
} 
to southeastern North Carolina. Winker and Howard (1977) considered each shoreline sequence to have been affected by Pleistocene crustal deformation (fig. 1C) and agreed with Oaks and DuBar (1974b) that emergent shoreline terrace/formations could not be correlated based solely on elevation. Winker and Howard (1977, p. 127) stated that “...terrace names..., given widespread application on the sole basis of elevation, are meaningless outside of their original localities and should be abandoned." Huddlestun (1988) incorporated both concepts of shoreline formation into his evolutionary model. Huddlestun considered terraces $\geq 10$ meters (m) elevation to have formed on, and have no genetic relation to the underlying deposits, but he also stated (p. 137),

"The Satilla Formation directly underlies the Pamlico and lower (or younger) marine terraces. Because the lithofacies distribution of the Satilla Formation appears to be related to the terrace landforms (i.e., barrier island and back-barrier features), the deposition of the Satilla appears to be related to the construction of the terraces..."

Like Cooke (1943), Herrick (1965), and Hoyt and Hails (1967), Huddlestun (1988) considered southeastern Georgia to be tectonically stable and unaffected by late Cenozoic uplift or subsidence. Relations among the mapped shoreline complexes of Lawton and others (1976), the regionally correlated shoreline sequences of Winker and Howard (1977), and the lithostratigraphic units of Huddlestun (1988) are shown for the LSRA in figure 3.

\section{Shoreline Age}

Published age assignments for SEACP emergent shoreline deposits in Georgia and South Carolina have been based on more than 100 years of regional and locally detailed, geologic mapping (lithology, stratigraphic position, and fossil content), soil and weathering profile investigations, and numerical ages from paleomagnetic, radiometric, chemical, and optical analyses (for example, Veatch and Stephenson, 1911; Darby and Hoyt, 1964; Pooser, 1965; Colquhoun, 1965; DuBar, 1971; DuBar and others, 1974; Campbell and others, 1975; Woolsey, 1976; Blackwelder and Ward, 1979; Blackwelder, 1981; Liddicoat and Opdyke, 1981; Liddicoat and others, 1981; McCartan and others, 1982; Pirkle and Czel, 1983; Cronin and others, 1984; McCartan and others, 1984; Szabo, 1985; Colquhoun, 1988; Huddlestun, 1988; Markewich and others, 1986, 1989; McCartan and others, 1990; Owens, 1990; Markewich and others, 1992; Markewich and Pavich, 1991, 1996; Weems and others, 1997; Weems and Edwards, 2001; Muhs and others, 2003; Wehmiller and others, 2004, 2010; Graybill and others, 2009; McGregor and others, 2011; Markewich and others, 2013; Doar and Kendall, 2014). Only a few of these studies focused on areas south of Charleston (fig. $1 B$ ), which has resulted in a paucity of ages and time-stratigraphic data for Pliocene and Pleistocene shoreline deposits in southeasternmost South Carolina and southeastern Georgia, including the LSRA (discussions in Markewich and others [1992, 2013] and Doar and Kendall [2014]). In this area, the lack of detailed geologic maps, the meager number and scattered nature of available age data, and lack of studies comparing dating techniques have precluded definitive correlation of shoreline deposits. The following section provides a synthesis of published and previously unpublished stratigraphic and age data for Pliocene, Pleistocene, and Holocene shoreline deposits in the LSRA. Specific details for previously unpublished data for the LSRA are included in the section, Details for Previously Unpublished Age and Stratigraphic Data and in appendix 1. 


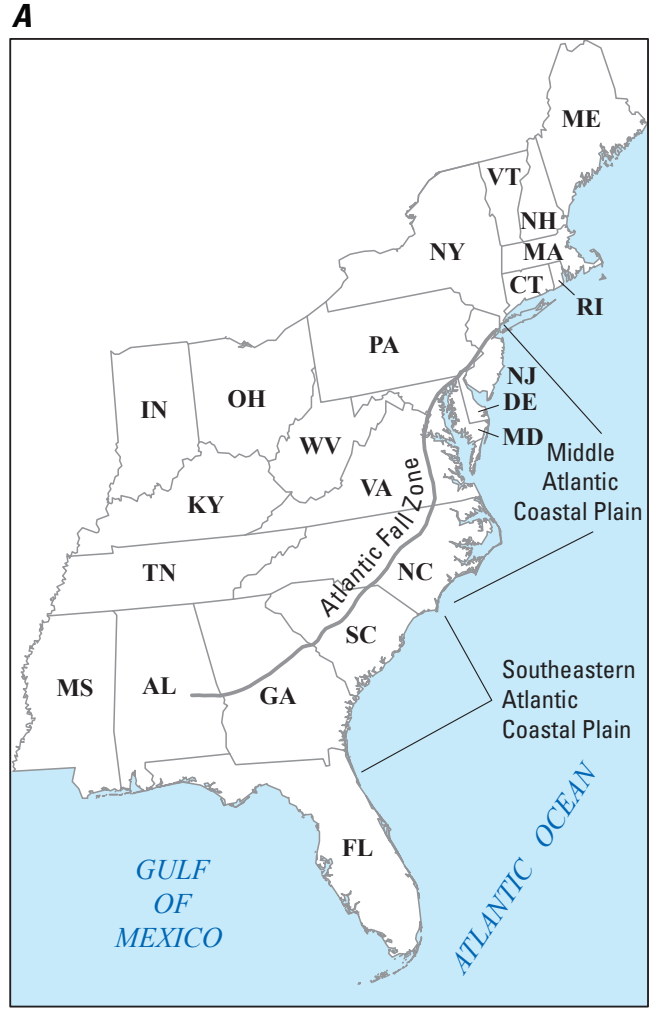

Base modified from 1:7,500,000-scale

U.S. Geological Survey digital files

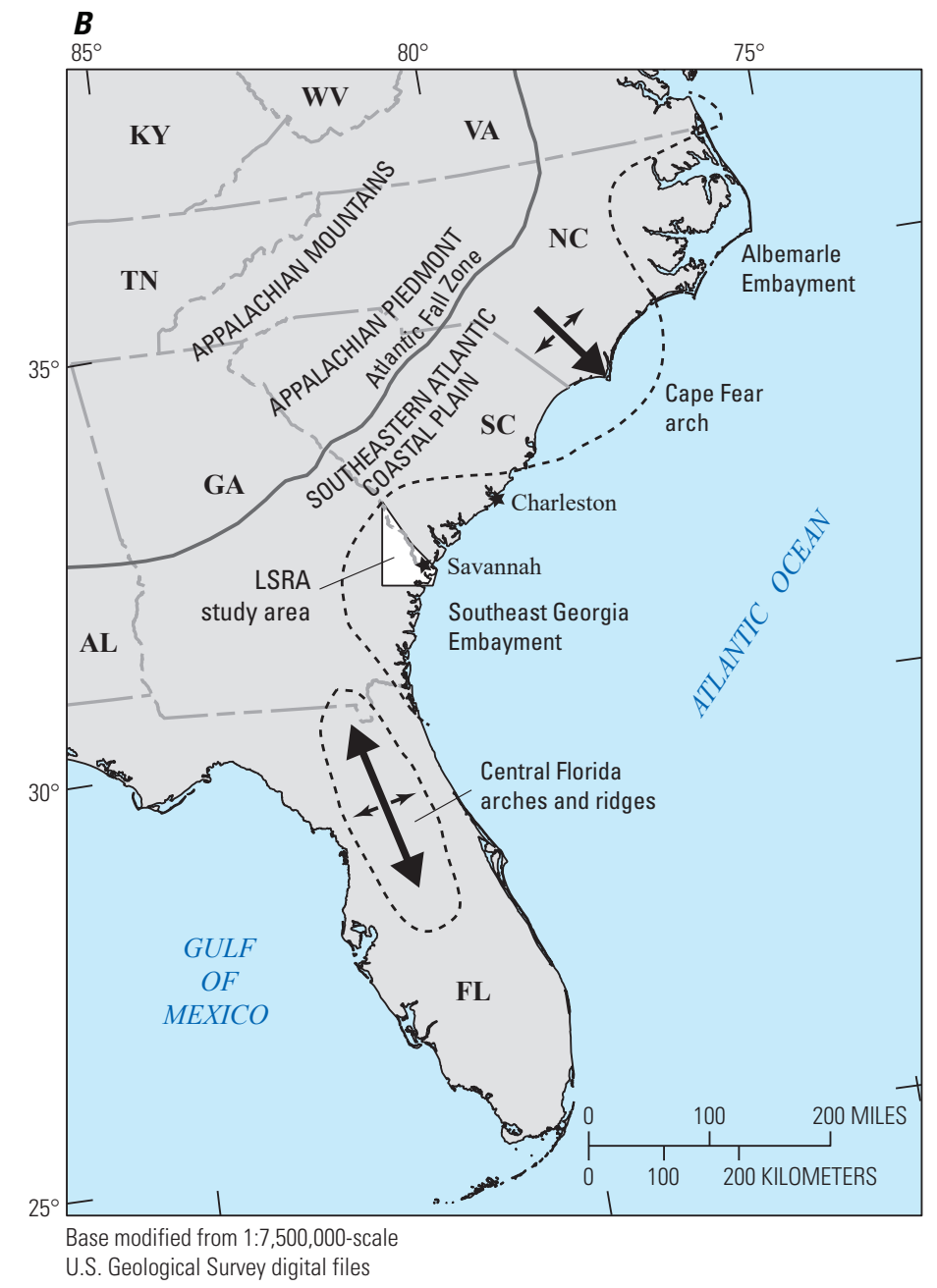

C
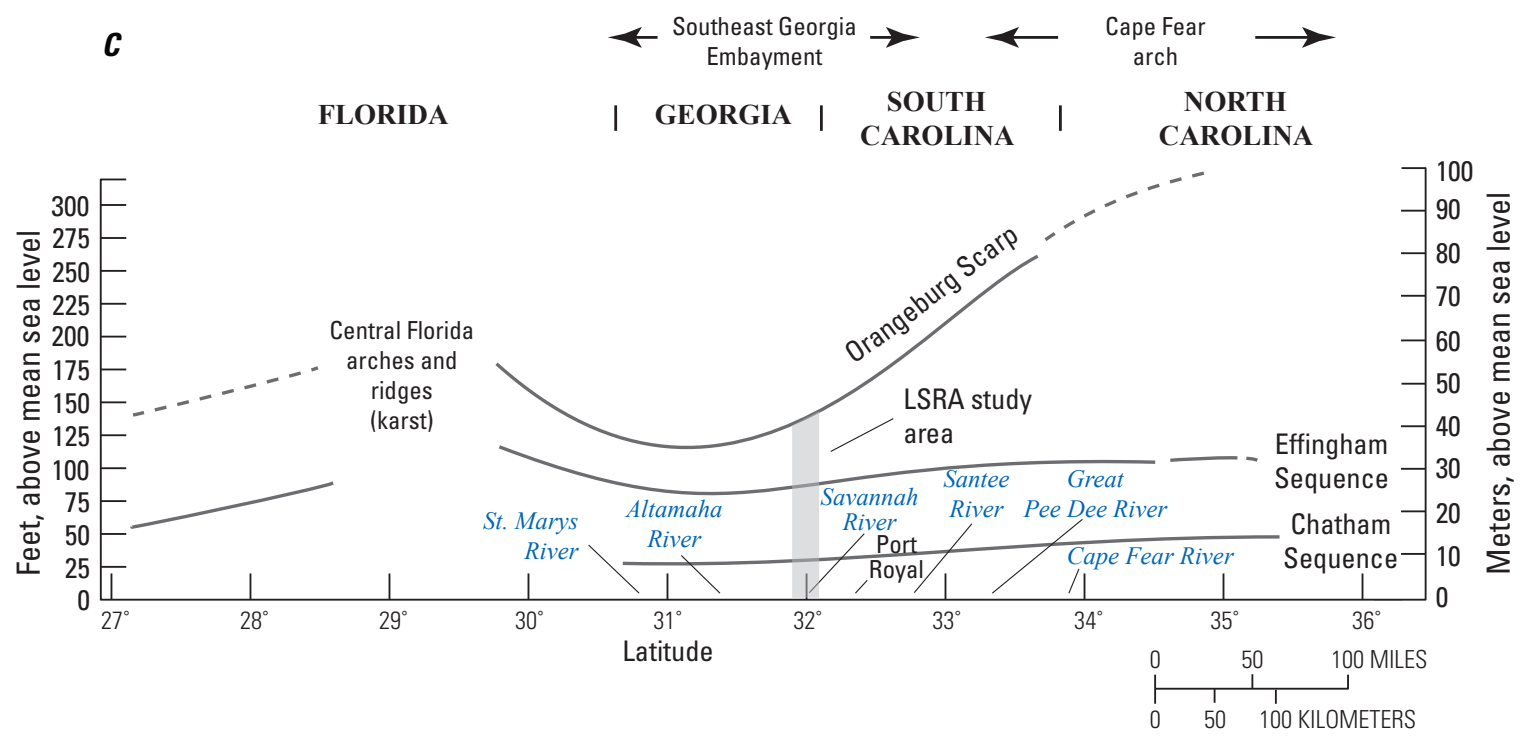

Figure 1. Map of the eastern United States of America $(A)$ showing the Atlantic Fall Zone, the middle Atlantic Coastal Plain, and the southeastern Atlantic Coastal Plain. (B) Map of the southeastern United States showing physiographic provinces, major arches and basins, and the lower Savannah River area (LSRA). (C) Latitudinal section showing State boundaries, locations of major rivers where they enter the Atlantic Ocean, location of the LSRA (gray vertical bar), spatial relations among emergent shoreline sequences and the arches and basins, and maximum sea level highstand elevations for each shoreline sequence (modified from fig. 3 in Winker and Howard, 1977). 


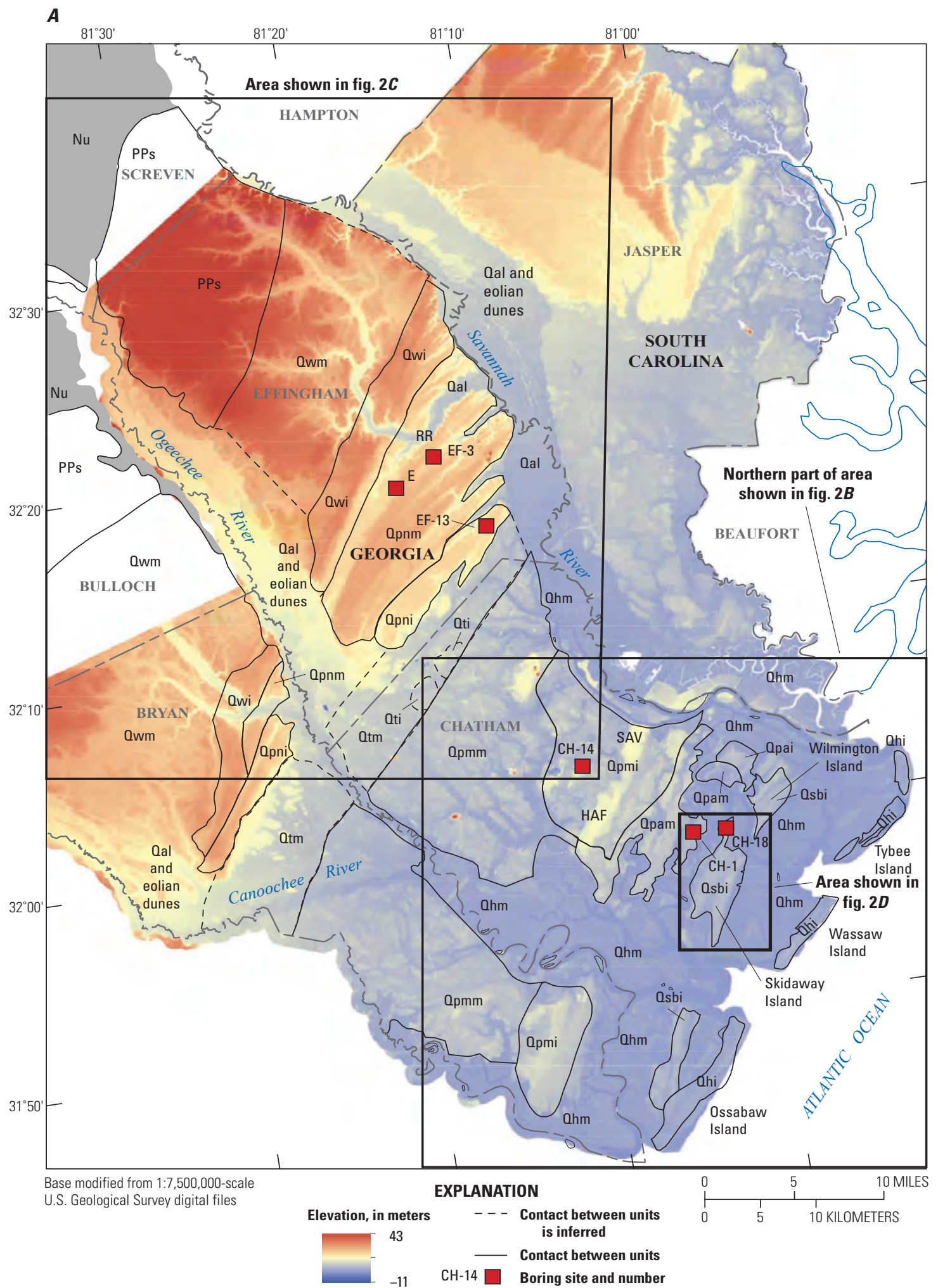

Figure 2. Maps showing political boundaries; geographic names; locations of described and sampled borrow pits, outcrops, and borings; and map units of Lawton and others (1976). A, Map units overlain onto a 1.22-meter-(m) raster digital-elevation model (DEM) of the lower Savannah River valley and adjacent terrain in Georgia and South Carolina. The DEM was generated from 1.0-point/ $\mathrm{m}^{2} \mathrm{light}$ detecting and ranging (lidar) bare-earth elevation datasets (South Carolina LiDAR Consortium, 2007; Chatham County Georgia, 2011; and Coastal Georgia Elevation Project, 2011). $B$ and $C$, Enlargements of map areas outlined by rectangles in figure $2 A$. $D$, Skidaway Island and Isle of Hope borings and sample locations and map units. Published and previously unpublished age data for each map unit of Lawton and others (1976) are in tables 1 and 2. OSL, optically stimulated luminescence. 


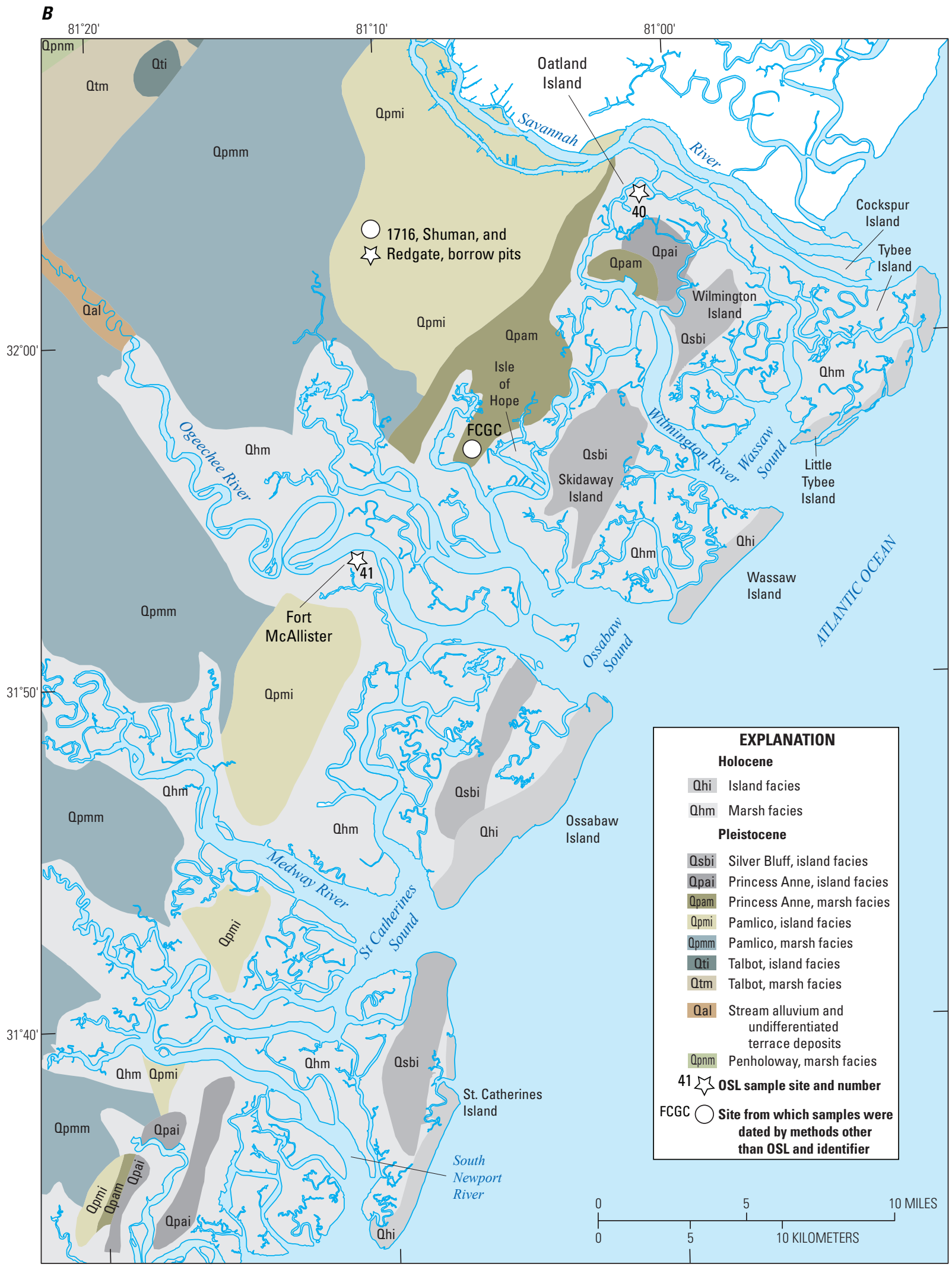

Base modified from 1:7,500,000-scale, U.S. Geological Survey digital files

Figure 2.-Continued 


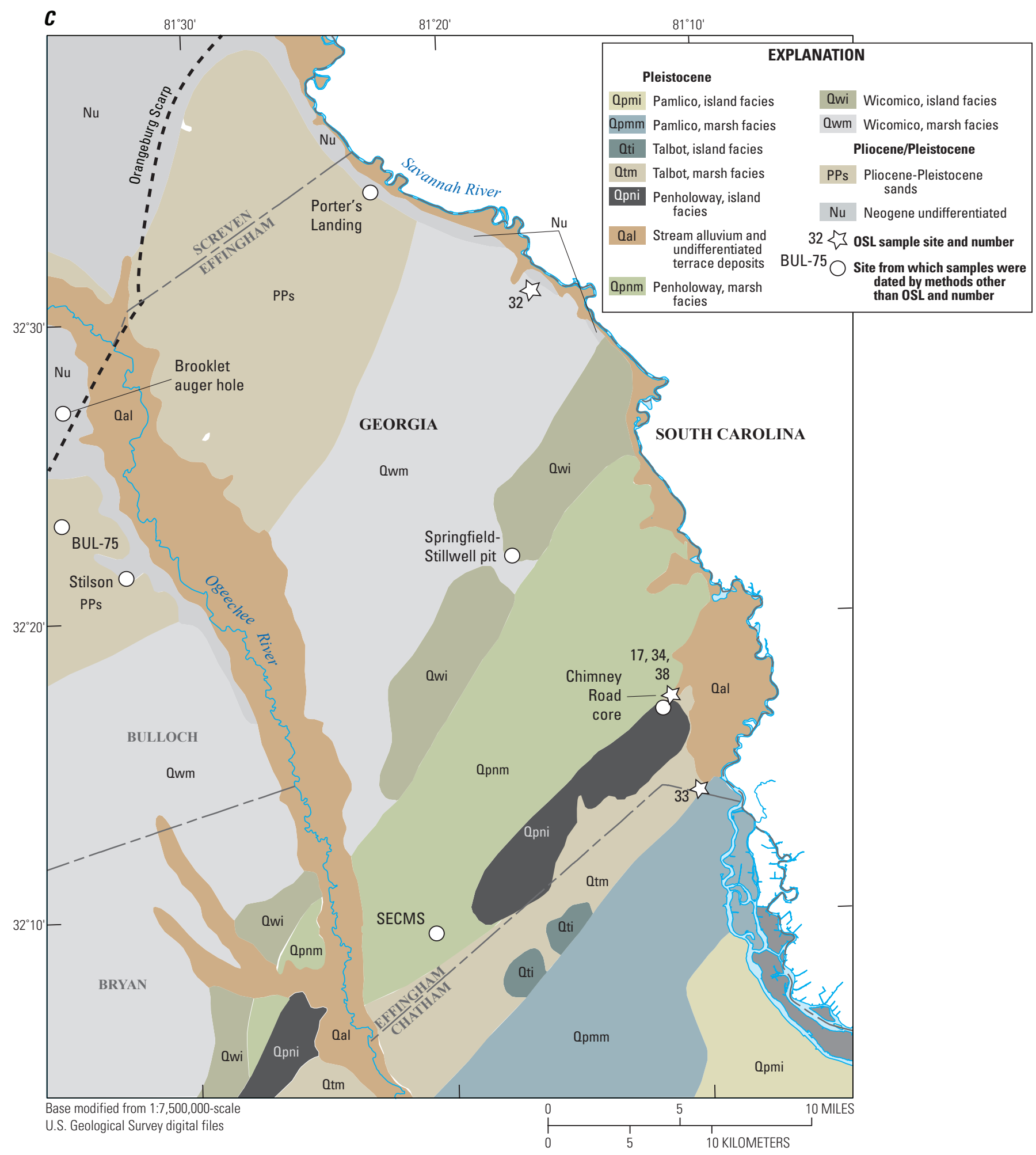

Figure 2.-Continued 


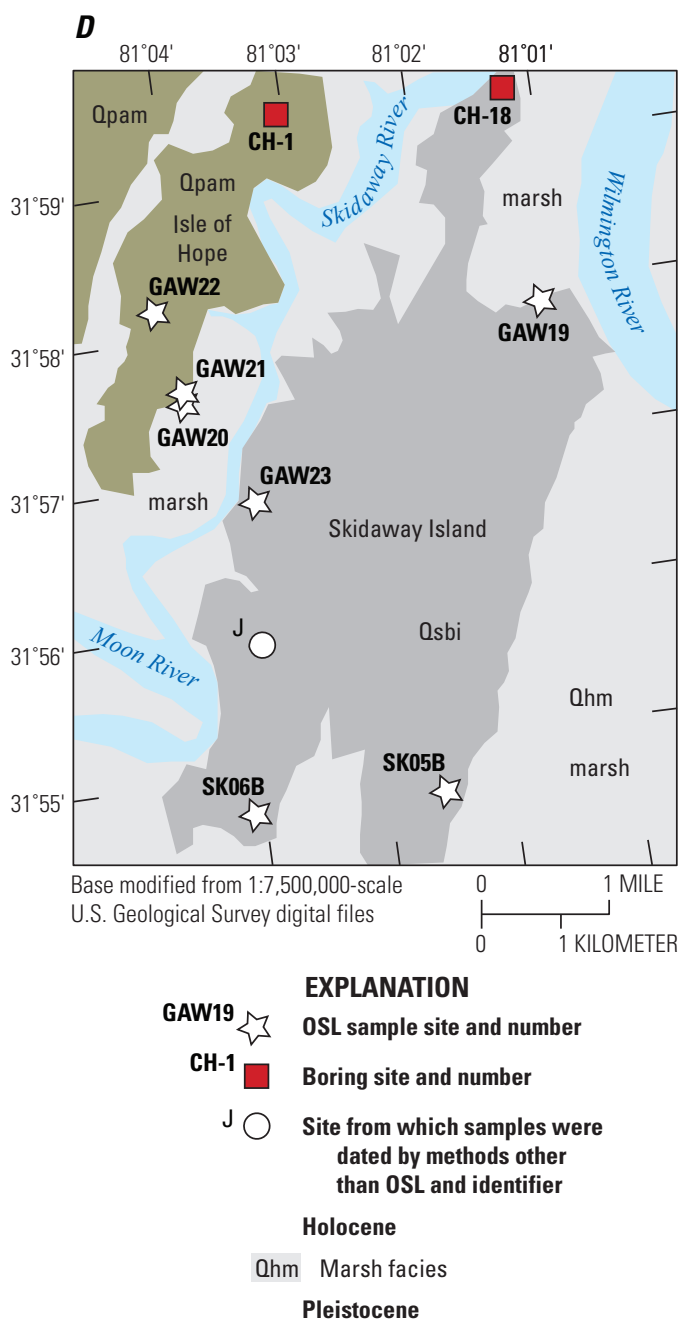

Qsbi Silver Bluff, island facies

Qpam Princess Anne, marsh facies

Figure 2.-Continued 


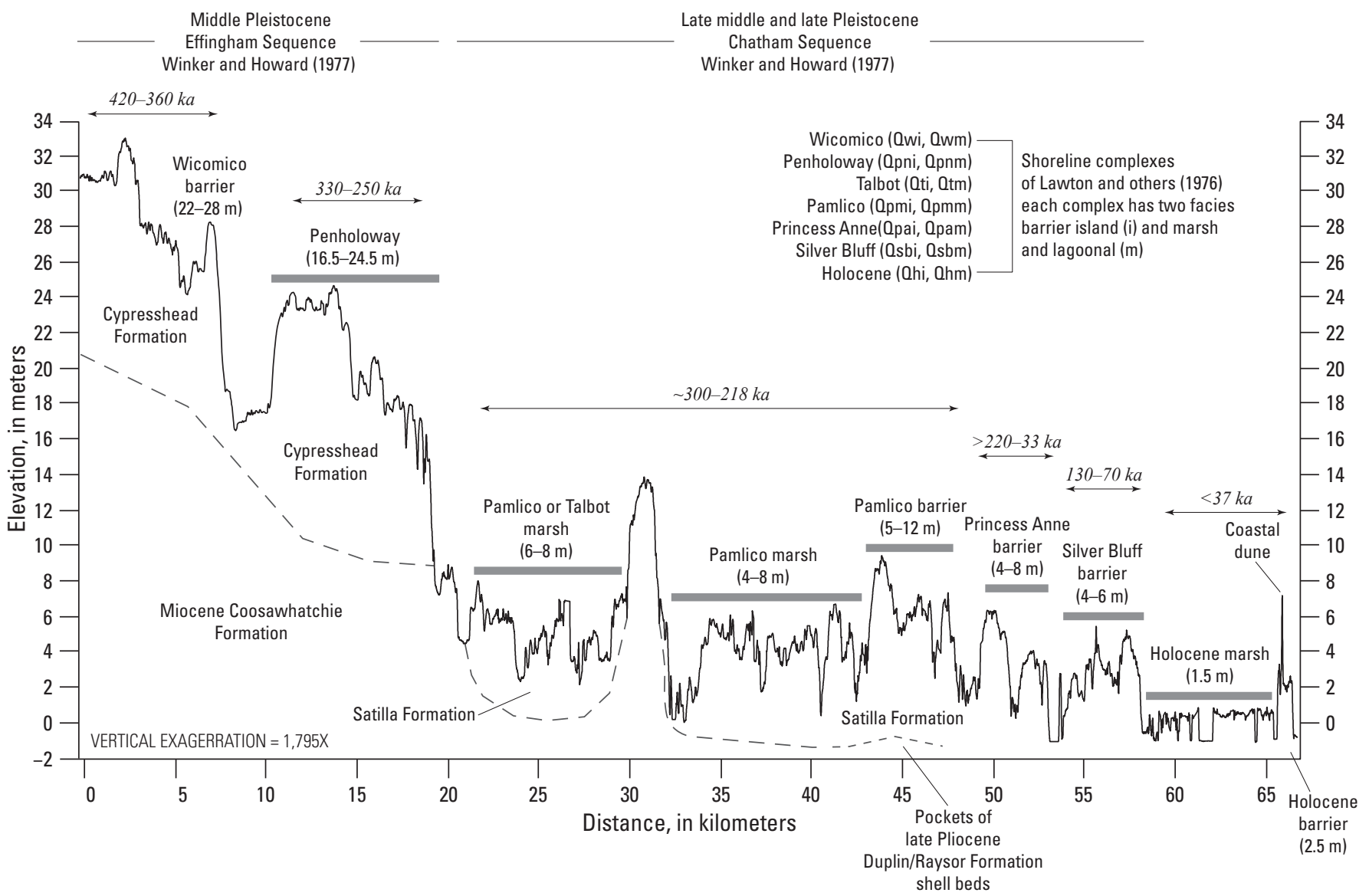

Figure 3. Age ranges and elevations for Pleistocene formations of Huddlestun (1988), shoreline sequences of Winker and Howard (1977), and shoreline complexes of Lawton and others (1976). Age data are from Wehmiller and others (1988), Booth and Rich (1999), Muhs and others (2003), Wehmiller and others (2004), chapters in Thomas (2008), Bishop and others (2011), Markewich and others (2013), Turck and Alexander (2013), and previously unpublished data presented in this report (tables 1-8). Modified from figure 3 in Markewich and others (2013). ka, age in thousands of years; m, meters.

\section{LSRA Shoreline Deposits and Shoreline Complexes-Stratigraphy and Age}

Map unit terminology for this report is that of Lawton and others (1976) as presented on the regional 1:500,000 scale Geologic Map of Georgia, which is the most recent geologic map available for southeastern Georgia, including the LSRA. Units are shown in relation to topography in figure $2 A$, and localities referred to in this report are shown in relation to map units in figure $2 A-D$. Age assignments for map units are based on published and previously unpublished stratigraphy and age data for emergent shoreline deposits associated with the Orangeburg Scarp and seaward of the Scarp. These data include fossil content, soil and weathering profile diagnostic properties (soil age indicator values), and numerical ages as determined by meteoric
Beryllium-10, paleosol $^{5}$ residence time ( ${ }^{10}$ BePRT), optically stimulated luminescence (OSL), uranium disequilibrium series (U-series), amino acid racemization (AAR), and radiocarbon $\left({ }^{14} \mathrm{C}\right)$ analyses. At many locations, minimum ages for shoreline deposits are based on previously unpublished and published ${ }^{10} \mathrm{BePRT}$, OSL, and ${ }^{14} \mathrm{C}$ ages for overlying fluvial and (or) eolian terrestrial deposits. Stratigraphy and age data are presented by map unit, from oldest to youngest. Age data by map unit are included in tables 1 and 2 . Specific details for previously unpublished ages and stratigraphic descriptions are included in figures $4-8$ and tables 3-8. Particle size data and chemistry for a few of these newly described deposits are included in tables $9-17$.

${ }^{5}$ The terms soil and paleosol are used interchangeably. A soil forms in place in geologic material. In general, a paleosol is a soil that has formed under very different conditions from those of the present climate. In the lower Savannah River area, soils/paleosols that have developed in emergent shoreline deposits and (or) in overlying eolian sand are several tens of thousands to more than 1 million years in age. These soils/paleosols have formed during periods of both wet and dry, cool temperate and warm temperate climates that have fluctuated with the growth and decay of continental ice sheets and the accompanying sea level lowstands and highstands. 
Table 1. Published and previously unpublished age data for late Pleistocene and Holocene near-shore marine and estuarine deposits in the lower Savannah River area, southeastern Georgia.

\begin{tabular}{|c|c|c|c|c|c|}
\hline $\begin{array}{l}\text { Geologic unit and } \\
\text { sample materiala }\end{array}$ & $\begin{array}{l}\text { Dating } \\
\text { method and } \\
\text { (number of } \\
\text { samples)b }\end{array}$ & $\begin{array}{c}\text { Sample ID and age, } \\
\text { in thousands of } \\
\text { years }\end{array}$ & Data sourcec & $\begin{array}{l}\text { Figure with sample } \\
\text { locality }\end{array}$ & $\begin{array}{l}\text { Ground surface elevation } \\
\text { and (sample elevation) at } \\
\text { sample locality, in meters }\end{array}$ \\
\hline $\begin{array}{l}\text { Qhi } \\
\text { oyster shell in } \\
\text { marine/estuarine } \\
\text { quartz sand }\end{array}$ & $\begin{array}{l}\text { AMS }{ }^{14} \mathrm{C} \\
\text { (1) }\end{array}$ & 4.3 & $\begin{array}{l}\text { Figure } 3 \text { in Swezey and } \\
\text { others (2018) }\end{array}$ & $\begin{array}{l}\text { Specific locality not } \\
\text { shown. }\end{array}$ & 1.0 \\
\hline \multicolumn{6}{|c|}{ Small islands in marsh between Skidaway and Wassaw Islands } \\
\hline \multirow[t]{2}{*}{$\frac{\mathrm{Qhm}}{\text { quartz sand }}$} & \multirow[t]{2}{*}{$\begin{array}{l}\text { OSL } \\
\text { (3) }\end{array}$} & $\begin{array}{l}\text { OSL07, } \\
1.556 \pm 0.22\end{array}$ & \multirow[t]{2}{*}{$\begin{array}{l}\text { Table } 7.2 \text { in Turck and } \\
\text { Alexander (2013) }\end{array}$} & \multirow{2}{*}{$\begin{array}{l}\text { Islands shown on } \\
\text { figure } 1 B \text {; specific } \\
\text { localities not shown. }\end{array}$} & $\begin{array}{l}\text { OSL07 } \\
1.7(0.55)\end{array}$ \\
\hline & & $\begin{array}{l}\text { OSL08, } \\
\quad 0.925 \pm 0.10\end{array}$ & & & $\begin{array}{l}\text { OSL08 } \\
\quad 0.2(-0.93)\end{array}$ \\
\hline \multirow[t]{2}{*}{$\frac{\mathrm{Qhm}}{\text { quartz sand }}$} & \multirow[t]{2}{*}{$\begin{array}{r}\text { OSL } \\
(2)\end{array}$} & $\begin{array}{l}\text { Oatland, } \\
\text { GAW40 } \\
35.1 \pm 2.1\end{array}$ & \multirow[t]{2}{*}{$\begin{array}{l}\text { Analytical data for } \\
\text { sample ages in } \\
\text { table } 3\end{array}$} & \multirow[t]{2}{*}{$\begin{array}{l}\text { Localities shown on } \\
\quad \text { figure } 2 B\end{array}$} & $\begin{array}{l}\text { GAW40 } \\
2(1.15)\end{array}$ \\
\hline & & $\begin{array}{l}\text { Fort McAllister, } \\
\text { GAW41 } \\
28.8 \pm 1.7\end{array}$ & & & $\begin{array}{l}\text { GAW41 } \\
2.7(1.8)\end{array}$ \\
\hline \multicolumn{6}{|c|}{ Wilmington Island } \\
\hline $\begin{array}{l}\text { Qsbi } \\
\text { shell in marine } \\
\text { quartz sand }\end{array}$ & $\begin{array}{l}{ }^{14} \mathrm{C} \\
(1)\end{array}$ & $\begin{array}{l}\text { WL- } 158 \\
42.6 \pm 3.7 \\
\text { (infinite) }\end{array}$ & Hoyt and others (1968) & $\begin{array}{l}\text { Specific locality not } \\
\text { shown. }\end{array}$ & $(-0.6)$ \\
\hline$\frac{\text { Qsbi }}{\text { Coral Septastrea }}$ & $\begin{array}{l}230 \mathrm{Th} / 238 \mathrm{U} \\
\text { (5) and } \\
231 \mathrm{~Pa} / 238 \mathrm{U} \\
\text { for } 3 \text { of } \\
\text { the } 5 \\
230 \mathrm{Th} / 238 \mathrm{U} \\
\text { samples }\end{array}$ & $87-82$ & $\begin{array}{l}\text { Jones Pit, table } 2 \text { in } \\
\text { Wehmiller and others } \\
(1997,2004)\end{array}$ & $\mathrm{J}$, on figure $2 D$ & $\begin{array}{l}4.2 \\
(-1.0 \text { to } 3.0)\end{array}$ \\
\hline $\begin{array}{l}\frac{\text { Qsbi }}{\text { many }} \\
\text { Mercenaria }\end{array}$ & $\begin{array}{l}\text { AAR } \\
\text { (many } \\
\text { samples) }\end{array}$ & $130-70$ & $\begin{array}{l}\text { Hulbert and Pratt } \\
\text { (1998) and figures } 18 \\
\text { and } 19 \text { in Muhs and } \\
\text { others (2003) }\end{array}$ & $\mathrm{J}$, on figure $2 D$ & $\begin{array}{l}4.2 \\
(-1.0 \text { to } 3.0)\end{array}$ \\
\hline \multirow[t]{2}{*}{$\frac{\text { Qsbi }}{\text { quartz sand }}$} & $\begin{array}{l}\text { OSL } \\
(2)\end{array}$ & $\begin{array}{l}\text { SK06B, } \\
\quad 45.80 \pm 10.20\end{array}$ & $\begin{array}{c}\text { Table } 7.2 \text { in Turck and } \\
\text { Alexander (2013) }\end{array}$ & Figure $2 D$ & $\begin{array}{l}\text { SK06B } \\
3.8(2.6)\end{array}$ \\
\hline & & $\begin{array}{l}\text { SK05B } \\
46.50 \pm 9.80\end{array}$ & & & $\begin{array}{l}\text { SK05B } \\
\quad 3.5(2.3)\end{array}$ \\
\hline
\end{tabular}


Table 1. Published and previously unpublished age data for late Pleistocene and Holocene near-shore marine and estuarine deposits in the lower Savannah River area, southeastern Georgia.-Continued

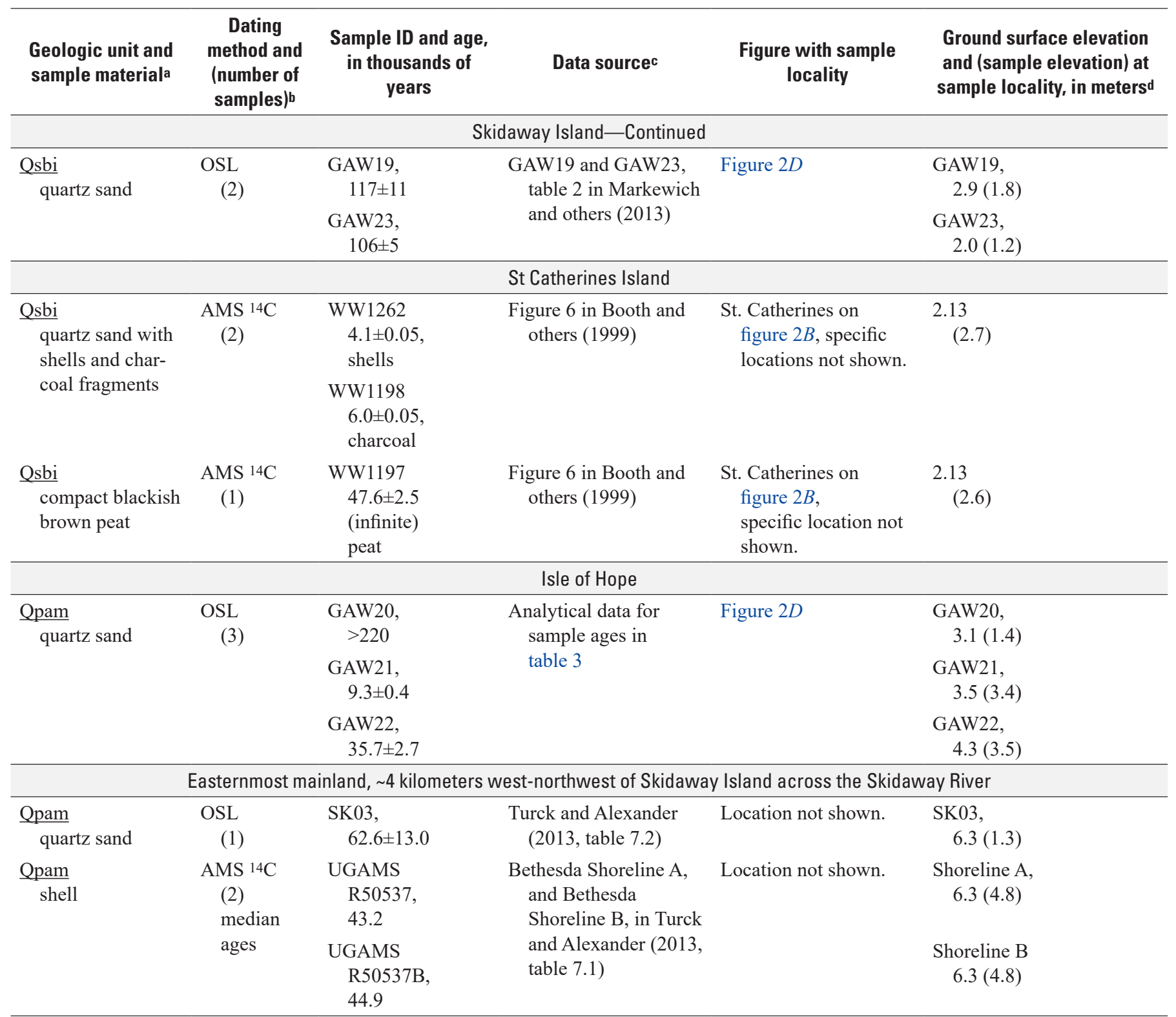

${ }^{\mathrm{a} G e o l o g y}$ is from Lawton and others (1976). Unit abbreviations explained on figure $2 B, C$ in this report.

bDating methods include: U-series, ${ }^{230} \mathrm{Th} / 238 \mathrm{U}$ and $231 \mathrm{~Pa} / 238 \mathrm{U}$; AAR, amino acid racemization; OSL, optically stimulated luminescence; AMS ${ }^{14} \mathrm{C}$, accelerator mass spectrometry radiocarbon and ${ }^{14} \mathrm{C}$, radiocarbon analysis that predates use of AMS.

cAnalytical data for previously unpublished OSL ages, for samples GAW20, 21, 22, 40, and 41, are in table 3. Samples were collected by authors of this report.

dSurface elevation determined from 1-point $/ \mathrm{m}^{2}$ light detecting and ranging (lidar) made available by Chatham County Georgia (2011) and the Coastal Georgia Elevation Project (2011). Sample elevation determined by subtracting the sample depth from the surface elevation of the sample location. Surface locations and elevations, for samples reported by Turck and Alexander (2013), were estimated by comparing the locations shown on figure 7.5 in their article to the 1-point $/ \mathrm{m}^{2}$ lidar 
Table 2. Published and previously unpublished age data for late Pliocene to middle Pleistocene near-shore marine and estuarine deposits in the lower Savannah River area, southeastern Georgia.

\begin{tabular}{|c|c|c|c|c|c|}
\hline $\begin{array}{l}\text { Geologic unit and } \\
\text { sample materiala }\end{array}$ & $\begin{array}{l}\text { Dating method } \\
\text { and (number of } \\
\text { samples)b }\end{array}$ & $\begin{array}{l}\text { Sample ID and } \\
\text { age, in thousands } \\
\text { of years }\end{array}$ & Data sourcec & $\begin{array}{l}\text { Figure with } \\
\text { sample locality }\end{array}$ & $\begin{array}{c}\text { Ground surface and } \\
\text { (sample elevation) } \\
\text { at sample locality, } \\
\text { in metersd }\end{array}$ \\
\hline \multicolumn{6}{|c|}{ Easternmost mainland, 4 kilometers west-northwest of Skidaway Island across the Skidaway River } \\
\hline$\frac{\text { Qpam }}{\text { Mollusks Mercenaria }}$ & $\begin{array}{l}\text { AAR } \\
\quad \text { (many samples) }\end{array}$ & $450-250$ & $\begin{array}{l}\text { Figures } 16,18,19 \text { in Muhs } \\
\text { and others }(2003)\end{array}$ & $\begin{array}{l}\text { FCGC on } \\
\text { figure } 2 B\end{array}$ & $\begin{array}{l}6.0 \\
\quad(-1.0 \text { to } 2.0)\end{array}$ \\
\hline$\frac{\text { Qpmi }}{\text { quartz sand }}$ & $\begin{array}{r}\text { OSL } \\
(2)\end{array}$ & $\begin{array}{l}1716 \mathrm{~A} \\
267 \pm 28 \\
1716 \mathrm{~B} \\
>290\end{array}$ & $\begin{array}{r}\text { Analytical data for OSL } \\
\text { sample ages in table } 3\end{array}$ & $\begin{array}{l}\text { Localities for the } \\
\text { three borrow } \\
\text { pits shown by } \\
\text { white circle }\end{array}$ & $\begin{array}{c}1716 \mathrm{~A}, \\
11(9.3) \\
1716 \mathrm{~B} \\
4(1.7)\end{array}$ \\
\hline $\begin{array}{l}\text { Qpmi } \\
\text { weathered and } \\
\text { pedogenically altered } \\
\text { quartz barrier sand, } \\
\text { locally overlain by } \\
\text { eolian sand }\end{array}$ & $\begin{array}{l}\text { 10BePRT } \\
\text { Shuman } \\
\text { (7) } \\
\text { Redgate } \\
(5)\end{array}$ & $\begin{array}{c}\text { Shuman, } \\
163\end{array}$ & $\begin{array}{l}\text { Analytical data for } \\
{ }^{10} \text { BePRT Shuman sample } \\
\text { ages in table } 6 \text { and for } \\
{ }^{10} \text { BePRT Redgate sample } \\
\text { ages in table } 7\end{array}$ & $\begin{array}{l}\text { on figure } 2 B \text {; } \\
\text { stratigraphy } \\
\text { for } 1716 \text {, on } \\
\text { figure } 6 A \text {, for } \\
\text { Shuman, on } \\
\text { figure } 6 B \text {, and } \\
\text { for Redgate, } \\
\text { on figure } 6 C\end{array}$ & $\begin{array}{l}\text { Shuman, } \\
\quad 9.5-10.5 \\
(6.0-10.0) \\
\text { Redgate, } \\
\quad 9.5-10.5 \\
(5.5-10)\end{array}$ \\
\hline
\end{tabular}

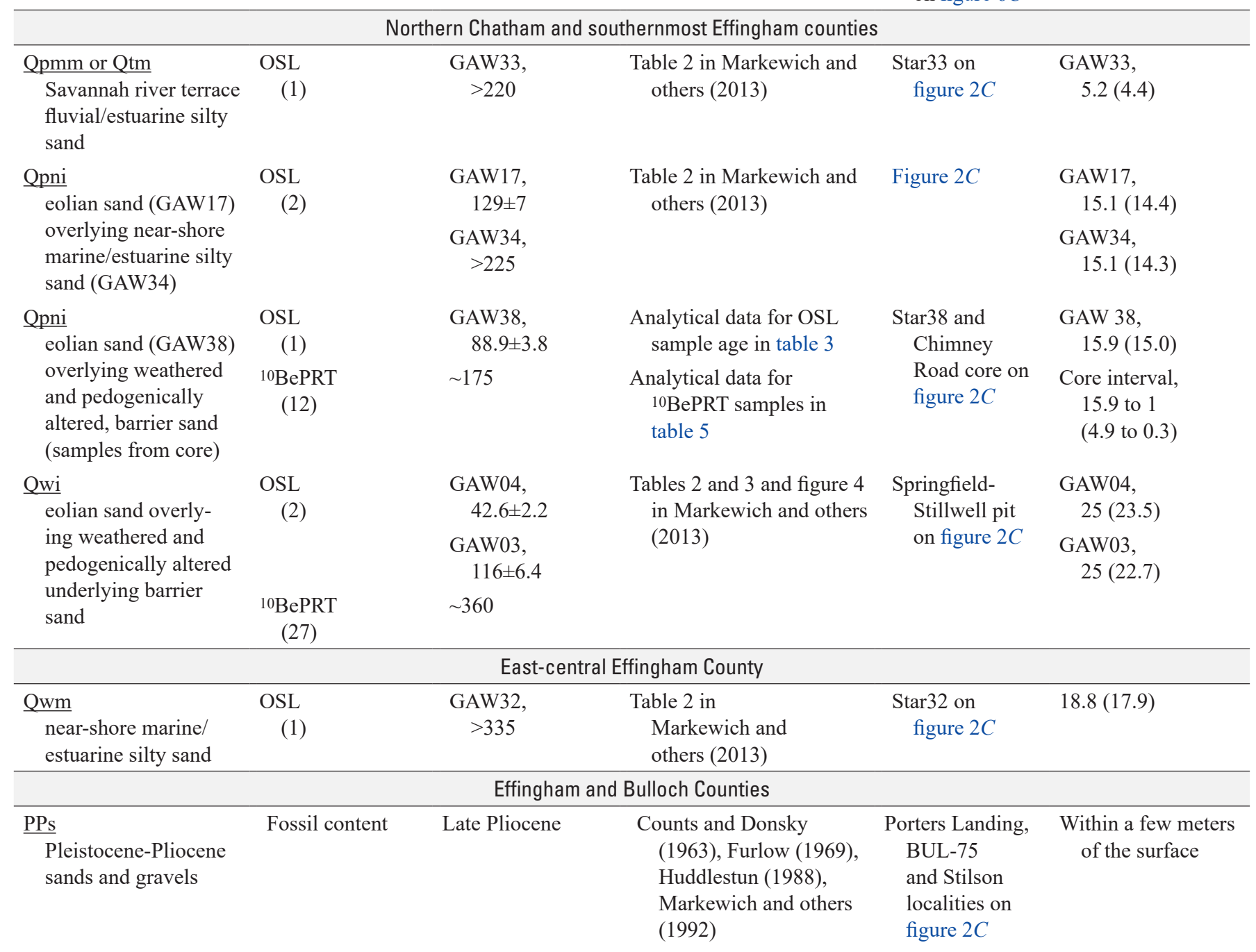


Table 2. Published and previously unpublished age data for late Pliocene to middle Pleistocene near-shore marine and estuarine deposits in the lower Savannah River area, southeastern Georgia.—Continued

\begin{tabular}{|c|c|c|c|c|c|}
\hline $\begin{array}{l}\text { Geologic unit and } \\
\text { sample materiala }\end{array}$ & $\begin{array}{l}\text { Dating method } \\
\text { and (number of } \\
\text { samples) }\end{array}$ & $\begin{array}{l}\text { Sample ID and } \\
\text { age, in thousands } \\
\text { of years }\end{array}$ & Data sourcec & $\begin{array}{c}\text { Figure with } \\
\text { sample locality }\end{array}$ & $\begin{array}{c}\text { Ground surface and } \\
\text { (sample elevation) } \\
\text { at sample locality, } \\
\text { in meters }\end{array}$ \\
\hline \multicolumn{6}{|c|}{ Bulloch County } \\
\hline $\begin{array}{l}\frac{\mathrm{Nu}}{\mathrm{marine}} \\
\text { sand and clay atop } \\
\text { Orangeburg Scarp }\end{array}$ & $\begin{array}{l}\text { 10Be soil-residence } \\
\text { time } \\
(9)\end{array}$ & $>1000$ & $\begin{array}{l}\text { Markewich and Pavich } \\
\text { (1996); table } 4 \text { in this } \\
\text { report }\end{array}$ & $\begin{array}{l}\text { Brooklet auger } \\
\text { hole on } \\
\text { figure } 2 C\end{array}$ & $\begin{array}{l}\text { Core interval, } \\
\quad \sim 62 \text { to } \sim 40 \text { meters }\end{array}$ \\
\hline
\end{tabular}

aGeology is from Lawton and others (1976). Unit abbreviations explained on figure $2 B, C$ in this report.

bDating methods include OSL, optically stimulated luminescence; AAR, amino acid racemization; and ${ }^{10}$ BePRT, Beryllium-10 paleosol residence time.

COSL and ${ }^{10} \mathrm{BePRT}$ samples were collected by authors of this report. Analytical data for the OSL ages, samples GAW38, 1716A, and 1716B are in table 3 . Analytical data for ${ }^{10} \mathrm{BePRT}$ ages are in tables $4-7$.

dSurface elevation determined from 1-point/ $\mathrm{m}^{2}$ light-detecting and ranging data made available by Chatham County Georgia (2011) and the Coastal Georgia Elevation Project (2011). Sample depth determined by subtracting the sample depth from the surface elevation of the sample location.

\section{Pliocene(?) or Older Deposits Atop and Landward of the Orangeburg Scarp}

Lawton and others (1976) did not identify the Orangeburg Scarp on their geologic map of Georgia. In the LSRA, the Scarp is located in the approximate position of their contact between the Neogene undifferentiated $(\mathrm{Nu})$ and the Pleistocene-Pliocene sands and gravels (PPs) map units (fig. 2C). Huddlestun (1988) referred to deposits landward of the Scarp as the Miocene Altamaha Formation. In the LSRA, there are no absolute age data for these deposits. Markewich and Pavich (1996) calculated a 650 -ka minimum ${ }^{10} \mathrm{BePRT}$ age for a paleosol developed in nearshore marine sand atop the Scarp (Brooklet auger hole on fig. 2C). They revised this age to a minimum of $700 \mathrm{ka}$ to $1 \mathrm{Ma}$ for this report ( ${ }^{10} \mathrm{BePRT}$ data in table 4$)$. The presence of late Pliocene deposits at the base of the Scarp indicates an age no younger than early late Pliocene for deposits landward and atop the Scarp. Brooklet deposit stratigraphy and soil description are included in figure 4.

\section{Late Pliocene and Early Pleistocene Deposits}

Identification and age assignments for late Pliocene and early Pleistocene deposits (PPs) seaward of the Orangeburg Scarp in southeastern Georgia are based on lithostratigraphy, stratigraphic position, and fossil content. No numerical age is available. Radiometric $\left({ }^{87} \mathrm{Sr} / 86 \mathrm{Sr}\right)$ ages are available for deposits identified as the Duplin and the Waccamaw Formations at several localities seaward of the Scarp in southeastern North Carolina. These ${ }^{87} \mathrm{Sr} / 86 \mathrm{Sr}$ ages indicate that the Duplin Formation was deposited in the late Pliocene and early Pleistocene (3.57 to $2.88 \mathrm{Ma}$ and 2.8 to $2.0 \mathrm{Ma}$ ) and the Waccamaw Formation in the early Pleistocene (2.12 to 1.5 Ma) (Graybill and others, 2009; McGregor and others, 2011). In the LSRA, discontinuous calcareous, sandy, and variably shelly deposits that are compositionally similar and difficult to differentiate occur seaward of the Scarp and have been referred to and (or) mapped as the Duplin Formation, the Raysor Formation, the Waccamaw(?) Formation, or Pleistocene-Pliocene sands and gravels (Counts and Donsky, 1963; Herrick, 1965; Furlow, 1969; Lawton and others, 1976; Huddlestun, 1988). Huddlestun (1988) referred to variably shelly, somewhat clayey, phosphatic, sandy, calcarenitic limestone and shelly quartz sand deposits in southeastern Georgia as the late Pliocene Raysor Formation. In this report, the term Duplin/Raysor is used for deposits in the LSRA that fit Huddlestun's description of the Raysor Formation, occur seaward of the Scarp, and are labelled as PPs in Lawton and others (1976; fig. 2A, C). In the LSRA, these deposits occur at or near the surface of a gently seaward-sloping plane (locations of Porters Landing, Stilson, and BUL-75 on fig. 2C), in numerous cores (Counts and Donsky, 1963; Herrick, 1965; Furlow, 1969; Huddlestun, 1988 and included references; Markewich and others, 1992; Weems and Edwards, 2001), and at the base of commercial borrow pits (fig. $6 A, B$ in this report). Fossil lists for Porters Landing and BUL-75 deposits are included in Markewich and others (1992). Based on lithology, stratigraphic position, and foraminifera assemblage, Huddlestun (1988; oral and written commun., 2010) identified Duplin/Raysor Formation deposits in the Chatham 1 core (CH-1 on fig. 2A, D). Weems and Edwards (2001) used lithology, stratigraphic position, and dinoflagellate and nanofossil assemblages to identify possible late Pliocene Duplin/Raysor strata in the Effingham County core (E on fig. 2A). Duplin/ Raysor deposits, identified by lithology and fossil content, occur at the base of the 1716 and Shuman borrow pits in Chatham County, Georgia (locations on fig. $2 B$, stratigraphy in fig. $6 A, B)$.

Huddlestun (1988) introduced and defined the Cypresshead Formation as a largely nonfossiliferous, variably thin to thick bedded, massive to cross bedded, bioturbated 

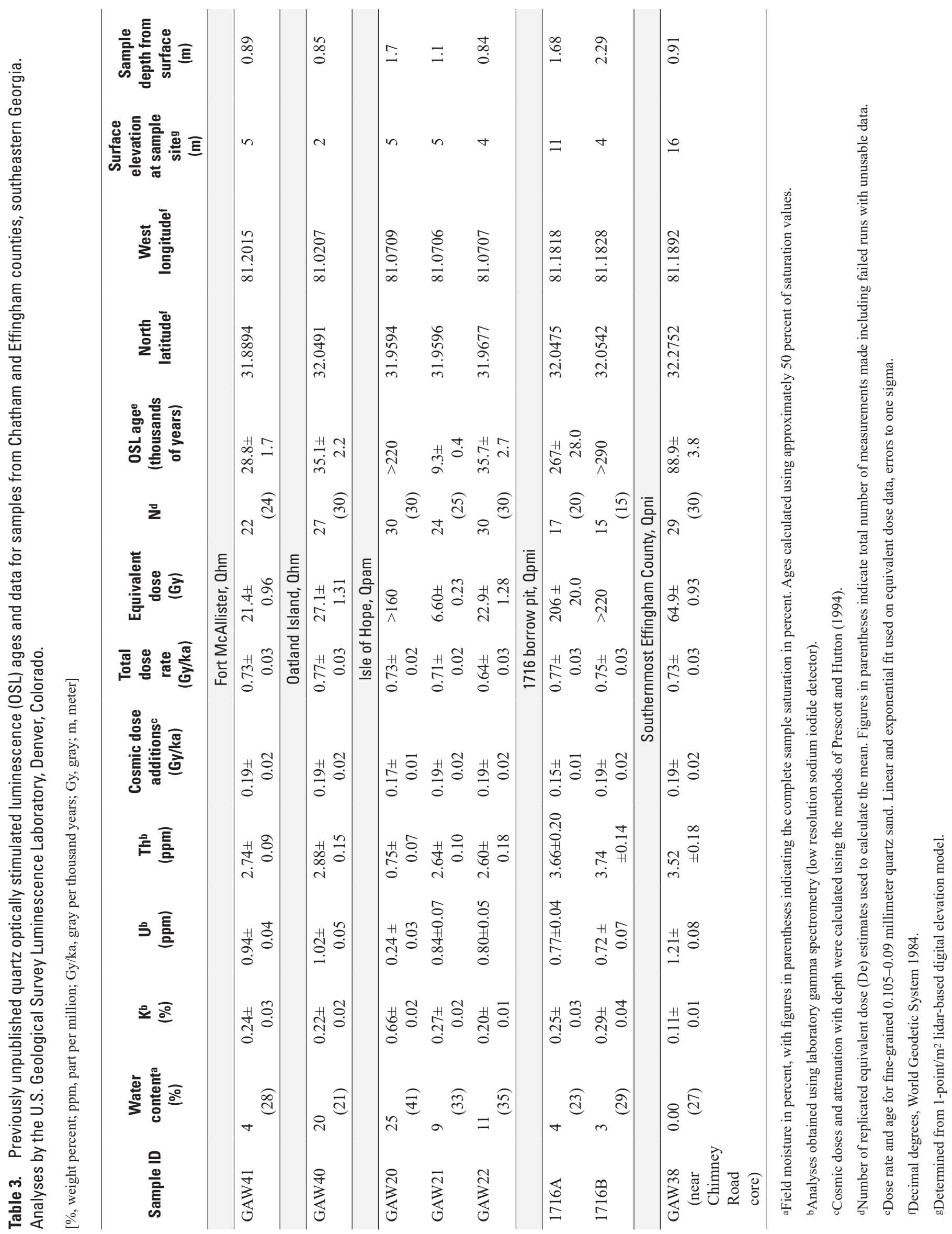
Table 4. Beryllium-10 concentration, horizon inventories, profile inventory, and minimum unit residence time, Brooklet auger hole, Bulloch County, Georgia (lat $32.4664^{\circ}$ N., long $81.6647^{\circ}$ W.; 63.4 meters surface elevation; location, fig. 2C; stratigraphy, fig. 4).

[The Brooklet profile inventory $=\sum$ horizon inventories $\left(104.210 \mathrm{Be}\right.$ atoms $\left./ \mathrm{cm}^{2} \times 10^{10}\right)$. The minimum unit residence time $t=-(1 / \lambda) \times \ln (1-\lambda N / q)$, where $N=$ horizon inventory (atoms $\left./ \mathrm{cm}^{2}\right)$, and $q=$ deposition rate $\left(1.3 \times 10^{6}\right.$ atoms $\left./ \mathrm{cm}^{2} / \mathrm{yr}\right)$, and $t$ is in thousands of years. The minimum residence time for the Brooklet auger hole deposit $=1,024,000$ years. $\mathrm{cm}$, centimeter; $\mathrm{cm}^{2}$, square centimeter; $\mathrm{cm}^{3}$, cubic centimeter; $\mathrm{g}$, gram]

\begin{tabular}{|c|c|c|c|c|c|c|c|}
\hline $\begin{array}{c}\text { Stratigraphy and } \\
\text { depositional } \\
\text { environment }\end{array}$ & $\begin{array}{c}\text { Brooklet } \\
\text { sample ID }\end{array}$ & $\begin{array}{l}\text { Depth-interval } \\
\text { (cm) }\end{array}$ & $\begin{array}{l}\text { Sample } \\
\text { deptha }^{-} \\
\text {(cm) }\end{array}$ & $\begin{array}{l}\text { Sample-interval } \\
\text { thickness } \\
(\mathrm{cm})\end{array}$ & $\begin{array}{c}\text { Bulk } \\
\text { density } \\
\left(\mathrm{g} / \mathrm{cm}^{3}\right)\end{array}$ & $\begin{array}{c}{ }^{10} \mathrm{Be} \\
\text { Concentration } \\
\text { (atoms/g x 108) }\end{array}$ & $\begin{array}{c}\text { Horizon } \\
\text { inventoryb } \\
\left({ }^{10 B e} \text { atoms/ }\right. \\
\left.\mathrm{cm}^{2} \times 10^{10}\right)\end{array}$ \\
\hline \multirow{3}{*}{$\begin{array}{l}\text { Nearshore-estuarine/ } \\
\text { marine, clayey, very } \\
\text { fine and fine quartz } \\
\text { sand with few quartz } \\
\text { pebbles }\end{array}$} & 2 & $120-334$ & 227.0 & 214.0 & 1.7 & 4.2 & 15.3 \\
\hline & 3 & $334-456$ & 395.0 & 122.0 & 1.7 & 1.8 & 3.7 \\
\hline & 5 & $547-760$ & 653.5 & 213.0 & 1.7 & 3.2 & 11.6 \\
\hline \multirow{4}{*}{$\begin{array}{l}\text { Nearshore-estuarine/ } \\
\text { marine, very well } \\
\text { sorted, very fine and } \\
\text { fine quartz sand }\end{array}$} & 6 & $760-1,064$ & 912.0 & 304.0 & 1.7 & 4.9 & 25.3 \\
\hline & 7 & $1,064-1,459$ & $1,261.5$ & 395.0 & 1.7 & 2.2 & 14.8 \\
\hline & 8 & $1,459-1,733$ & $1,596.0$ & 274.0 & 1.7 & 1.5 & 7.0 \\
\hline & 9 & $1,733-1,885$ & $1,809.0$ & 152.0 & 1.7 & 1.7 & 4.4 \\
\hline
\end{tabular}

aSample depth is measured from the ground surface.

bHorizon inventory $=$ concentration $\left(10^{8} \mathrm{x}\right.$ atoms $\left./ \mathrm{g}\right) \mathrm{x}$ horizon thickness $(\mathrm{cm}) \mathrm{x}$ bulk density $\left(\mathrm{g} / \mathrm{cm}^{3}\right)$.

to burrowed, fine to coarse grained to pebbly quartz sand that occurs stratigraphically above his Raysor Formation. Huddlestun recognized the Cypresshead Formation as occurring throughout southeastern Georgia, including the LSRA. In the LSRA, Cypresshead Formation deposits are exposed in railroad cuts (RR on fig. 2A), stream banks, and roadcuts, and occur in numerous cores (Effingham 3, EF-3; Effingham 13, EF-13; Chatham 14, CH-14 on fig. 2A). Based on stratigraphic position and foraminiferal content, Huddlestun (1988) considered the Cypresshead Formation to be late Pliocene to early Pleistocene in age. In the LSRA, deposits of Huddlestun's Cypresshead Formation include the Pleistocene-Pliocene sands and gravels (PPs) and the Wicomico (Qwi), Penholoway (Qpn), and Talbot (Qt) Shoreline Complexes as delineated in Lawton and others (1976). The stratigraphic relations between the Cypresshead Formation and the shoreline complexes in the LSRA are shown on figure 3 .

\section{Pleistocene Shoreline Complexes}

The seven mapped Pleistocene shoreline complexes delineated in Lawton and others (1976) stratigraphically overlie and occur seaward of the deposits mapped as PPs. Each shoreline complex has a barrier islands (i) and a marsh and lagoonal $(\mathrm{m}$ ) facies (fig. $2 A-D$ ). The following generalized physiographic descriptions and elevations for Pleistocene shoreline complexes in the LSRA vary somewhat from the descriptions and elevations of these complexes/formations by Hoyt and Hails (1967). Their descriptions were for these complexes/formations as they are manifest in all of southeastern Georgia.
- Wicomico Shoreline Complex (Qwi and Qwm; fig. 2A,C). Qwi deposits are expressed as a distinct southwest to northeast trending barrier/beach-ridge at 24 to $28 \mathrm{~m}$, which is somewhat lower than the $30 \mathrm{~m}$ elevation, broad topographically flat Qwm deposits that are present landward of the barrier/beach-ridge. The seaward toe of the Wicomico barrier/beach-ridge is at $20 \mathrm{~m}$. The barrier/beach-ridge is separated from the younger Penholoway Shoreline Complex by a 2to 4-km-wide valley, except near the Savannah River where the complexes are adjacent.

- Penholoway Shoreline Complex (Qpni and Qpnm; fig. 2A,C). Qpni and Qpnm deposits form a series of arcuate cuspate barrier/inter-barrier deposits with both facies occurring between 19 and $24 \mathrm{~m}$. The seaward toe of the complex is between 10 and $12 \mathrm{~m}$.

- Talbot Shoreline Complex (Qti and Qtm; fig. 2A-C). Qti and Qtm deposits are not well expressed in the LSRA. As mapped, Qti deposits occur at two small localities with upper surfaces between 12 and $14 \mathrm{~m}$. Qti deposits have a seaward toe between 6 and $8 \mathrm{~m}$. Mapped Qtm deposits occur between 6 and $8 \mathrm{~m}$ in a southwest to northeast trending band landward of Qti deposits. Qtm deposits are either overlain or not distinguishable from the younger marsh and lagoonal deposits of the Pamlico Shoreline Complex.

- Pamlico Shoreline Complex (Qpmi and Qpmm; fig. 2A-C). Qpmi deposits are expressed as a series of relatively broad barrier flats between 6 to $9 \mathrm{~m}$ 
that locally reach 10 to $14 \mathrm{~m}$ and have a seaward toe between 5 and $6 \mathrm{~m}$. The city of Savannah and Hunter Army Airfield (SAV and HAF on figure $2 A$ ) are located on the most prominent Qpmi barrier deposit. Qpmm deposits occur between 4 and $7 \mathrm{~m}$ and form an unusually wide ( 24 to $32 \mathrm{~km}$ ) gently seaward-sloping plane landward of, and locally surrounding, Qpmi deposits.

- Princess Anne Shoreline Complex (Qpai and Qpam; fig. 2A, $B, D$ ). Qpai deposits are mapped in one very small area at about $4 \mathrm{~m}$. Qpam deposits are mapped seaward of Qpmi deposits and landward of the Skidaway River at 4 to $6 \mathrm{~m}$.

- Silver Bluff Shoreline Complex (Qsbi and Qsbm; fig. 2A, $B, D$ ). As mapped, Qsbi deposits reach $3 \mathrm{~m}$ elevation and include Wilmington and Skidaway islands and the landward half of Ossabaw Island. Qsbm deposits are either overlain or not distinguishable from the younger marsh-lagoonal deposits of the Holocene Shoreline Complex.

- Holocene Shoreline Complex (Qhi and Qhm; fig. 2A, $B, D$ ). Qhi deposits include Tybee, Wassaw, and the seaward half of Ossabaw islands (fig. 2A, $B$ ). These deposits reach 2 to $3 \mathrm{~m}$, except on Wassaw Island where a high dune ridge reaches 13 to $14 \mathrm{~m}$. Qhm deposits extend tens of kilometers up the Savannah and Ogeechee river valleys and surround barrier island facies deposits of the Silver Bluff Shoreline Complex.

\section{Wicomico Shoreline Complex (Owi and Qwm)}

The Wicomico Shoreline Complex (Qwi and Qwm on figs. 2A, $C$ and 3 ) is the most landward morphologically identifiable coastal landform seaward of Orangeburg Scarp in the LSRA, and includes the highest ridge of the Effingham Sequence of Winker and Howard (1977) (fig. 3). Winker and Howard (1977) estimated the age of the Effingham Sequence to be between 2 and 1 Ma. Huddlestun (1988) included these deposits in his late Pliocene to early Pleistocene Cypresshead Formation. Based on soil age indicator values and OSL and ${ }^{10} \mathrm{BePRT}$ data for Wicomico barrier/beach-ridge deposits and the overlying eolian dune sand at the Springfield-Stillwell pit locality (location on fig. 2), Markewich and others (2013) calculated a 360-ka minimum age for these barrier deposits. Using OSL ages for marine and eolian deposits seaward and landward of the Wicomico barrier/beach-ridge, they estimated a 420- to 360-ka age range for the Wicomico Shoreline Complex. Age data for the Wicomico Shoreline Complex are included in tables 2 and 8.

\section{Penholoway Shoreline Complex (Opni and Opnm)}

The Penholoway Shoreline Complex (Qpni and Qpnm on figs. $2 A, C$, and 3 ) is an 8- to $11-\mathrm{km}$-wide sequence of fluvial-marine deposits. Winker and Howard (1977) considered these to be cuspate delta deposits and included them in their Effingham Sequence. Huddlestun (1988) included these deposits in his Cypresshead Formation (fig. 3). Penholoway shoreline deposits are exposed in railroad cuts (for example, RR on fig. $2 A$ ), in road cuts, and have been identified in core (Effingham County core of Weems and Edwards, 2001; E on fig. 2A). Lithostratigraphic and soil profile descriptions for Penholoway Shoreline Complex barrier deposits (Qpni) in the Chimney Road core (location on fig. 2C) are shown in figure 5. OSL and ${ }^{10} \mathrm{BePRT}$ ages for shoreline and overlying eolian deposits at this and nearby localities indicate a minimum age of $260 \mathrm{ka}$ and an age range of 360 to $260 \mathrm{ka}$ for the Penholoway Shoreline Complex. Specific details of lithostratigraphic and age data for deposits at the Chimney Road core are included in figure 5 and in table 5 .

\section{Talbot Shoreline Complex (Oti and Qtm)}

The Talbot Shoreline Complex is not well represented in the LSRA (Qti and Qtm on fig. 2A-C). Possible Qti and Qtm deposits are exposed in commercial borrow pits, in core, and in areas mapped as Penholoway and Talbot Shoreline Complexes. No age data are available for these deposits that occur as the most seaward southwest ridge of the Penholoway Shoreline Complex, as topographic remnants/islands of Qti deposits, or as middle Miocene to Pliocene fluvial-marine to marine deposits surrounded by marsh and lagoonal deposits of the Talbot and (or) Pamlico Shoreline Complex (Qtm and Qpmm, respectively). Alemán-González and others (2018) referred to these deposits as the late Pliocene to early Pleistocene Cypresshead Formation in the upper $21 \mathrm{~m}$ of the South Effingham County Middle School core (SECMS on fig. $2 C$ ). At the SECMS and a few other localities these undated fluvial marine deposits overlie middle Miocene marine strata (L.E. Edwards, U.S. Geological Survey, written commun., 2012). Based on ages for deposits of the Penholoway and Pamlico Shoreline Complexes, Talbot Shoreline Complex deposits, if present, are late middle Pleistocene in age.

\section{Pamlico, Princess Anne, Silver Bluff and Holocene Shoreline Complexes}

Winker and Howard (1977, fig. 2) included the Pamlico and younger formations of Hoyt and Hails (1974) and shoreline complexes of Lawton and others (1976) in their Chatham Sequence (fig. 3 in this report). Huddlestun (1988) did not agree with the morphostratigraphic concept that identified each emergent shoreline sequence/shoreline complex as a geologic formation (previous references). Huddlestun's 


\section{BROOKLET AUGER HOLE}

Surface elevation 63.4 meters; lat $32.4664^{\circ} \mathrm{N}$., long $81.6647^{\circ} \mathrm{W}$.

Depth,

in meters

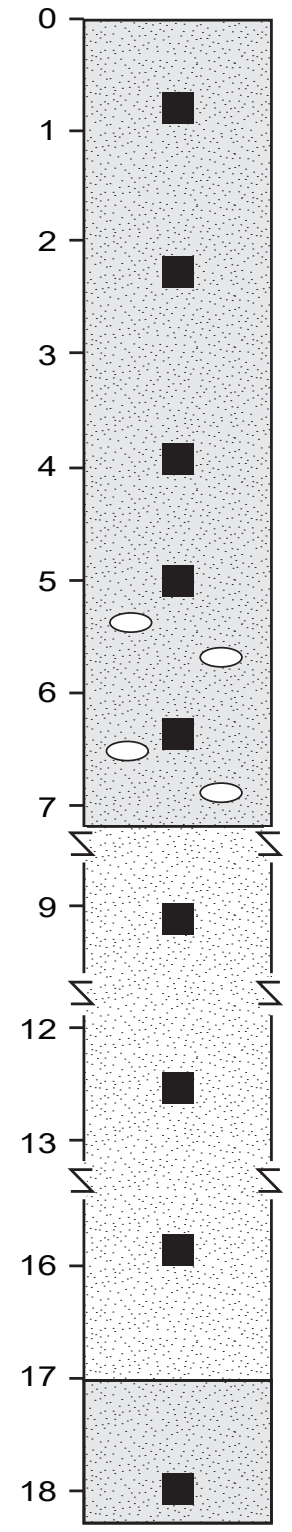

Tifton loamy sand soil series (fine-loamy kaolinitic, thermic Plinthic Kandiudult) developed in very-fine and fine quartz sand;

Iron concretions in upper $150 \mathrm{~cm}$;

Plinthite below $150 \mathrm{~cm}$;

High chroma 10R colors (red $4 / 6$ to $4 / 8$ and dark red $3 / 6$ ) are prominent, especially from $0-200 \mathrm{~cm}$;

Low and high chroma 2.5 YR colors (grey and red) throughout from 2-8 m;

7.5YR $5 / 8$ and 10 YR $5 / 8$ B horizons;

2.5YR 4/6-4/8 and 5YR 5/8 streaks and mottles in reticulate patterns of the $B$ and $\mathrm{C}$ horizons;

Pedon thickness $\sim 220 \mathrm{~cm}$;

B horizon thickness $\sim 150 \mathrm{~cm}$;

Kaolinite is dominant clay mineral with minor gibbsite, goerthite, quartz and vermiculite in the surface $2 \mathrm{~m}$;

$\sim 30-40$ weight percent clay in 50-cm-thick maximum Bt horizon;

Weathered $C$ horizon from base of $B$ horizon $(220 \mathrm{~cm})$ to $800+\mathrm{cm}$

5-8 $\mathrm{m}$ sandy clay and clay with few quartz pebbles

5YR 8/2 (pinkish white) and 5YR 7/4-7/8 (pink to reddish yellow) to 10R 6/6 (light red), extremely well-sorted very-fine and fine micaceous quartz sand with 1-3 weight percent heavy minerals;

Kaolinite is dominant clay mineral with minor cristobalite and illite

(10) $8 / 2-8 / 5$ extremely well-sorted, very-fine and fine micaceous quartz sand with 1-3 weight percent heavy minerals;

Kaolinite is dominant clay mineral with minor cristobalite and illite

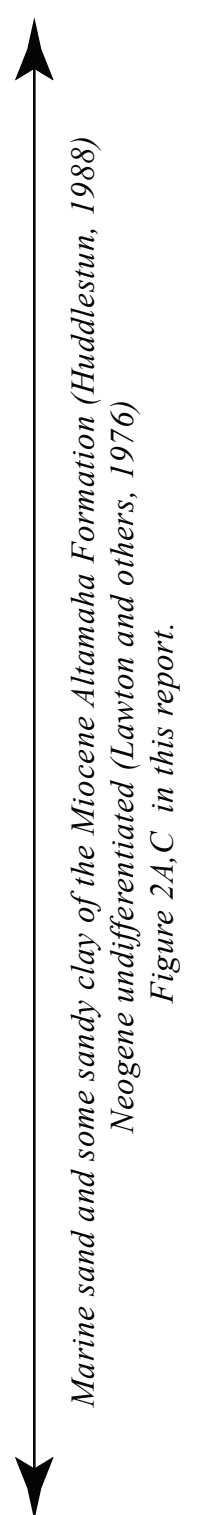

\section{EXPLANATION}

Sample for meteoric ${ }^{10} \mathrm{Be}$ isotope analysis

$\triangle$ Break in scale

Figure 4. Lithostratigraphy and general pedologic description for the probable late Pliocene to earliest Pleistocene near-shore marine-sand at the top of the Orangeburg Scarp (fig. 2C) in Bulloch County, Georgia (Brooklet auger hole locality on fig. 2C). Beryllium-10 paleosol residence time (10BePRT) data are included in table $4 . \mathrm{cm}$, centimeter. 
exception was his late Pleistocene Satilla Formation, which Huddlestun considered to be genetically linked to the Pamlico, Princess Anne, and Silver Bluff-Holocene terraces that he identified in southeastern Georgia (fig. 3 in this report). He assigned a late Pleistocene age to the Satilla Formation on the basis that the formation contained only extant late Pleistocene and reworked Pliocene and early Pleistocene fauna. The numerous numerical ages presented herein for deposits of the Pamlico, Princess Anne, Silver Bluff, and Holocene Shoreline Complexes of Lawton and others (1976) support Huddlestun's late Pleistocene age assignment for his Satilla Formation. The occurrence of Holocene as well as Pleistocene age deposits in the Princess Anne, Silver Bluff, and Holocene Shoreline Complexes indicate that these map units are complex, contain nearshore sediments primarily deposited from 200,000 to several thousand years ago, and continue to be affected by ongoing coastal processes. ${ }^{6}$ Age data are included in tables 1 and 2.

\begin{abstract}
${ }^{6}$ The reader is referred to Harris and others (2005) for a discussion of the influence of geologic framework variability on a coastland that has evolved over a broad range of spatial and temporal scales. As an example, the tidal range at the entrance of the Savannah River to the Atlantic Ocean is 2 to 4 meters $(\mathrm{m})$. With added storm surge, storm tides reach $6 \mathrm{~m}$. The effect of storms that produce significant storm surge can be seen on the Chatham County Storm Surge Map for Hurricane Mathew (2016), which shows areas mapped as Princesses Anne, Silver Bluff, and Holocene shoreline complexes covered by 0.3 to $3.0 \mathrm{~m}$ of water (https://twitter.com/chathamema/status/ $784181731817553920)$.
\end{abstract}

Table 5. Beryllium-10 concentration, horizon inventories, profile inventory, and minimum unit residence time, Chimney Road (CMRD) core, Effingham County, Georgia (lat $32.2753^{\circ}$ N., long $81.1892^{\circ}$ W.; 15.9 meters surface elevation; location, fig. 2C; stratigraphy, fig. 5).

[The Chimney Road profile inventory $=\sum$ horizon inventories, $25.25{ }^{10} \mathrm{Be}$ atoms $/ \mathrm{cm}^{2} \times 10^{10}$. The minimum unit residence time $t=-(1 / \lambda) \times \ln (1-\lambda N / q)$, where $N=$ horizon inventory (atoms $\left./ \mathrm{cm}^{2}\right)$, and $q=$ deposition rate $\left(1.3 \times 10^{6}\right.$ atoms $\left./ \mathrm{cm}^{2} / \mathrm{yr}\right)$, and $t$ is in thousands of years. The Chimney Road minimum residence time at the base of the eolian sand $=27,000$ years. The Chimney Road minimum residence time for deposits beneath the eolian sand $=174,900$ years. The minimum residence time for the Chimney Road core deposit $=201,900$ years. $\mathrm{cm}$, centimeter; $\mathrm{cm}^{2}$, square centimeter; $\mathrm{cm}^{3}$, cubic centimeter; g, gram]

\begin{tabular}{|c|c|c|c|c|c|c|c|}
\hline $\begin{array}{c}\text { Stratigraphy and } \\
\text { depositional environment }\end{array}$ & $\begin{array}{l}\text { CMRD } \\
\text { sample ID }\end{array}$ & $\begin{array}{l}\text { Depth-interval } \\
\text { (cm) }\end{array}$ & $\begin{array}{l}\text { Sample } \\
\text { deptha }^{\circ} \\
\text { (cm) }\end{array}$ & $\begin{array}{c}\text { Sample- } \\
\text { interval } \\
\text { thickness } \\
\text { (cm) }\end{array}$ & $\begin{array}{c}\text { Bulk } \\
\text { density } \\
\left(\mathrm{g} / \mathrm{cm}^{3}\right)\end{array}$ & $\begin{array}{c}10 \mathrm{Be} \\
\text { concentration } \\
\text { (atoms/g } \\
\times 10^{8} \text { ) }\end{array}$ & $\begin{array}{c}\text { Horizon } \\
\text { inventoryb } \\
\text { (10Be atoms/ } \\
\left.\text { cm }^{2} \times 10^{10}\right)\end{array}$ \\
\hline \multirow[t]{3}{*}{ Eolian quartz sand } & 1 & $0-82.3$ & 30.5 & 82.3 & 1.70 & 0.9 & 1.3 \\
\hline & $1 b$ & $82.3-91.4$ & 86.9 & 9.1 & 1.70 & 2.9 & 0.4 \\
\hline & 2 & $91.4-95$ & 91.4 & 3.6 & 1.70 & 0.7 & 0.0 \\
\hline Estuarine quartz sand & 4 & $152.4-204.2$ & 190.5 & 51.8 & 1.70 & 5.8 & 5.1 \\
\hline $\begin{array}{l}\text { Near-shore marine/estuarine } \\
\text { quartz sand }\end{array}$ & 5 & $204.2-228.6$ & 221.0 & 24.4 & 1.70 & 5.3 & 2.2 \\
\hline \multirow[t]{2}{*}{ Fluvial/estuarine quartz sand } & $5 b$ & $228.6-262.1$ & 245.4 & 33.5 & 1.70 & 4.1 & 2.3 \\
\hline & 6 & $262.1-283.5$ & 266.7 & 21.4 & 1.70 & 2.8 & 1.0 \\
\hline \multirow{3}{*}{$\begin{array}{l}\text { Alternating beds of marginal } \\
\text { marine estuarine fine to } \\
\text { coarse quartz sand with } \\
\text { interbeds of silt and clay }\end{array}$} & 10 & $387.1-420.6$ & 400.8 & 33.5 & 1.7 & 2.5 & 1.4 \\
\hline & 11 & $420.6-472.4$ & 443.5 & 51.8 & 1.7 & 4.4 & 3.8 \\
\hline & 12 & $472.4-481.6$ & 477.0 & 9.2 & 1.7 & 5.8 & 0.9 \\
\hline
\end{tabular}

aSample depth is measured from the ground surface.

bHorizon inventory $=$ concentration $\left(10^{8} \mathrm{x}\right.$ atoms $\left./ \mathrm{g}\right) \times$ horizon thickness $(\mathrm{cm}) \mathrm{x}$ bulk density $\left(\mathrm{g} / \mathrm{cm}^{3}\right)$. 


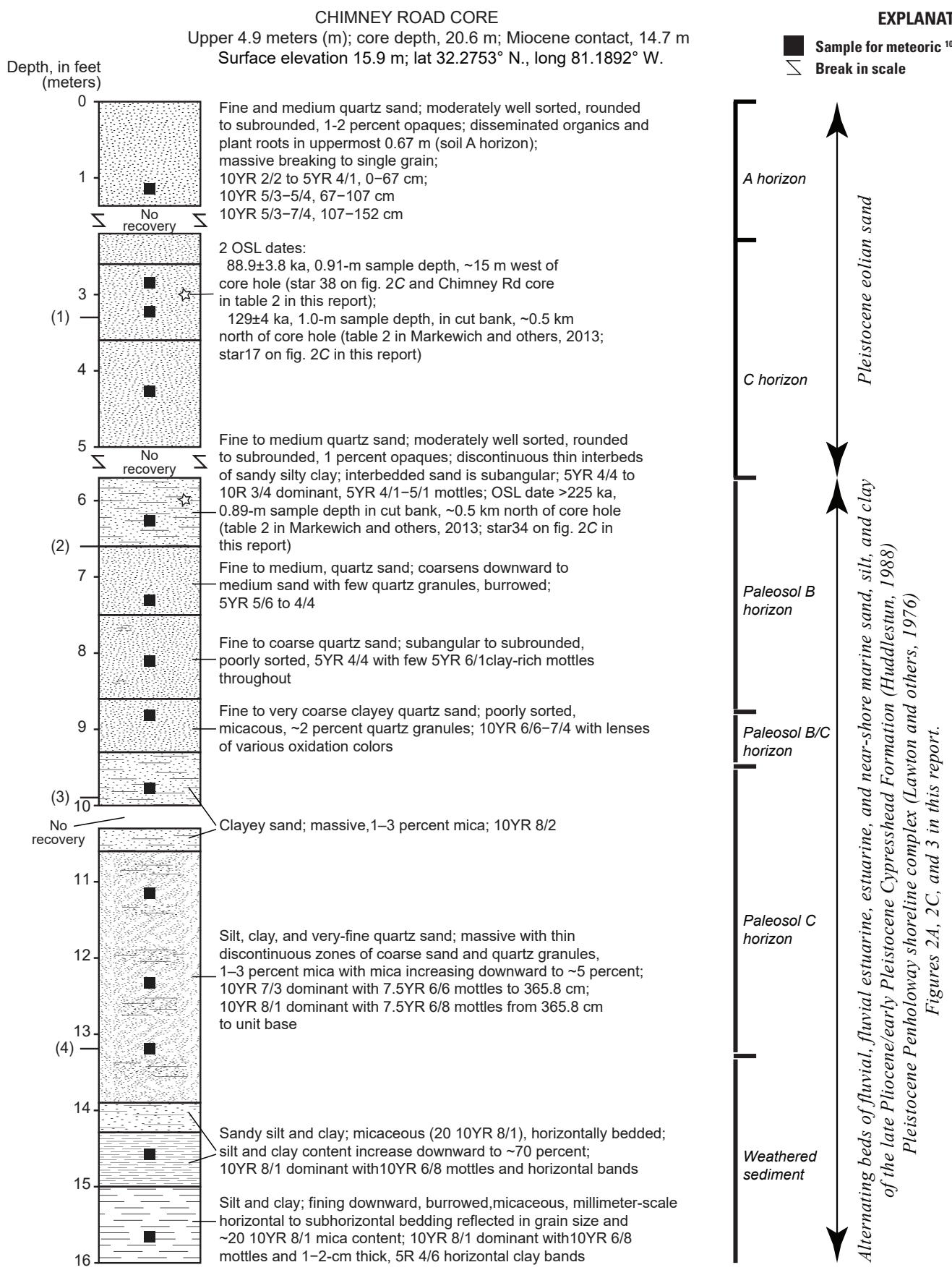

Figure 5. Lithostratigraphy, general pedologic description, and optically stimulated luminescence (OSL) age data (from nearby localities) for Penholoway barrier deposits (Qpni on fig. 2C) and overlying eolian sand in Effingham County, Georgia (Chimney Road core locality on fig. 2 C). Beryllium-10 residence time data are included in table 5. Locations for OSL samples shown on figure 2C. OSL age data are in tables 2 and 3 in this report and in table 2 of Markewich and others (2013). cm, centimeter; ka, age in thousands of years; km, kilometer. 


\section{Pamlico Shoreline Complex (Qpmi and Qpmm)}

The Pamlico Shoreline Complex is the most geomorphically prominent of the four youngest complexes. Qpmi deposits occur in an 8- to 10-km-wide belt of 1-km-or-more-wide barrier ridges and flats surrounded by Pamlico and younger marsh-lagoonal deposits (fig. 2A, B). On one of these broad barrier flats, three large, no-longer-accessible, commercial borrow pits (1716, Shuman, and Redgate on fig. 2B) exposed a 7to $12-\mathrm{m}$-thick transgressive sequence of fluvial, fluvial-marine, and barrier/beach-ridge deposits (stratigraphy on fig. 6A-C). Previously unpublished age data based on soil and weathering physical and chemical parameters and ${ }^{10} \mathrm{BePRT}$ and OSL analyses indicate a 300 to $200 \mathrm{ka}$ late middle Pleistocene age for these Qpmi deposits (tables 2, 3, 6, 7, 8). Specific age data for deposits that were exposed in these borrow pits are included in tables $3,6,7$, and figure $6 A-C$.

Table 6. Beryllium-10 concentration, horizon inventories, profile inventory, and minimum unit residence time, Shuman borrow pit, Chatham County, Georgia (lat $32.0533^{\circ}$ N., long $81.1600^{\circ}$ W., 9-9.5 meters surface elevation; location, fig. 2B; stratigraphy, fig. 6B).

[The Shuman profile inventory $=\sum$ horizon inventories, $20.3{ }^{10} \mathrm{Be}$ atoms $/ \mathrm{cm}^{2} \times 10^{10}$. The minimum unit residence time $t=-(1 / \lambda) \times \ln (1-\lambda N / q)$, where $N=$ horizon inventory (atoms $\left./ \mathrm{cm}^{2}\right)$, and $q=$ deposition rate $\left(1.3 \times 10^{6}\right.$ atoms $/ \mathrm{cm}^{2} / \mathrm{yr}$ ), and $t$ is in thousands of years. The minimum residence time for the Shuman borrow pit deposit $=162,600$ years. $\mathrm{cm}$, centimeter; $\mathrm{cm}^{2}$, square centimeter; $\mathrm{cm}^{3}$, cubic centimeter; $\mathrm{g}$, gram]

\begin{tabular}{|c|c|c|c|c|c|c|c|}
\hline $\begin{array}{c}\text { Stratigraphy and } \\
\text { depositional } \\
\text { environment }\end{array}$ & $\begin{array}{l}\text { Shuman } \\
\text { sample ID }\end{array}$ & $\begin{array}{l}\text { Depth-interval } \\
\text { (cm) }\end{array}$ & $\begin{array}{c}\text { Sample } \\
\text { deptha }^{\text {de }} \\
\text { (cm) }\end{array}$ & $\begin{array}{l}\text { Sample- } \\
\text { interval } \\
\text { thickness } \\
\text { (cm) }\end{array}$ & $\begin{array}{l}\text { Bulk density } \\
\qquad\left(\mathrm{g} / \mathrm{cm}^{3}\right)\end{array}$ & $\begin{array}{c}10 \mathrm{Be} \\
\text { concentration } \\
\text { (atoms/g } \\
\times 10^{8} \text { ) }\end{array}$ & $\begin{array}{c}\text { Horizon } \\
\text { inventoryb } \\
(10 \mathrm{Be} \text { atoms } \\
\left.\mathrm{cm}^{2} \times 10^{10}\right)\end{array}$ \\
\hline \multirow{5}{*}{$\begin{array}{l}\text { Near-shore marine/ } \\
\text { estuarine very- } \\
\text { fine and fine, } \\
\text { quartz sand with } \\
\text { Ophiomorpha bur- } \\
\text { rows in the rela- } \\
\text { tively unweathered } \\
\text { parent material }\end{array}$} & 2 & $50-120$ & 85.0 & 70.0 & 1.5 & 1.5 & 1.6 \\
\hline & 3 & $120-170$ & 145.0 & 50.0 & 1.5 & 2.9 & 2.2 \\
\hline & 5 & $210-283$ & 246.5 & 73.0 & 1.5 & 4.3 & 4.7 \\
\hline & 6 & $283-313$ & 298.0 & 30.0 & 1.5 & 3.9 & 1.8 \\
\hline & 7 & $313-398$ & 355.5 & 85.0 & 1.5 & 3.0 & 3.8 \\
\hline
\end{tabular}

aSample depth is measured from the ground surface.

bHorizon inventory $=$ concentration $\left(10^{8} \mathrm{x}\right.$ atoms $\left./ \mathrm{g}\right) \mathrm{x}$ horizon thickness $(\mathrm{cm}) \mathrm{x}$ bulk density $\left(\mathrm{g} / \mathrm{cm}^{3}\right)$.

Table 7. Beryllium-10 concentration, horizon inventories, profile inventory, and minimum unit residence time, Redgate borrow pit, Chatham County, Georgia (lat $32.0417^{\circ}$ N., long $81.1667^{\circ}$ W., 9.5-10.0 meters surface elevation; location, fig. 2B; stratigraphy, fig. 6C).

[The Redgate profile inventory $=\sum$ horizon inventories, $28.3{ }^{10} \mathrm{Be}$ atoms $/ \mathrm{cm}^{2} \times 10^{10}$. The minimum unit residence time $t=-(1 / \lambda) \times \ln (1-\lambda N / q)$, where $N=$ horizon inventory (atoms $\left./ \mathrm{cm}^{2}\right)$, and $q=$ deposition rate $\left(1.3 \times 10^{6} \mathrm{atoms} / \mathrm{cm}^{2} / \mathrm{yr}\right)$, and $t$ is in thousands of years. The minimum residence time for the Redgate borrow pit deposit $=230,800$ years. $\mathrm{cm}$, centimeter; $\mathrm{cm}^{2}$, square centimeter; $\mathrm{cm}^{3}$, cubic centimeter; g, gram; m, meter]

\begin{tabular}{|c|c|c|c|c|c|c|c|}
\hline $\begin{array}{c}\text { Stratigraphy and depositional } \\
\text { environment }\end{array}$ & $\begin{array}{l}\text { Redgate } \\
\text { sample ID }\end{array}$ & $\begin{array}{c}\text { Depth- } \\
\text { interval } \\
\text { (cm) }\end{array}$ & $\begin{array}{c}\text { Sample } \\
\text { deptha } \\
\text { (cm) }\end{array}$ & $\begin{array}{l}\text { Sample- } \\
\text { interval } \\
\text { thickness } \\
\text { (cm) }\end{array}$ & $\begin{array}{c}\text { Bulk } \\
\text { density } \\
\left(\mathrm{g} / \mathrm{cm}^{3}\right)\end{array}$ & $\begin{array}{c}10 \mathrm{Be} \\
\text { concentra- } \\
\text { tion } \\
(\text { atoms } / \mathrm{g} \\
\left.\times 10^{8}\right)\end{array}$ & $\begin{array}{c}\text { Horizon } \\
\text { inventoryb } \\
\text { (10Be atoms/ } \\
\left.\text { cm² }^{2} \times 10^{10}\right)\end{array}$ \\
\hline \multirow{4}{*}{$\begin{array}{l}\text { Near-shore marine/estuarine very- } \\
\text { fine and fine, quartz sand with } \\
\text { Ophiomorpha burrows in the } \\
\text { parent material; some very thin } \\
\text { and thin flasers; below } 9.4 \text { m, } \\
\text { sand-matrix-supported gravel lo- } \\
\text { cally cemented with silica and (or) } \\
\text { phosphate }\end{array}$} & 1 & $0-91$ & 45 & 91 & 1.5 & 2.6 & 3.6 \\
\hline & 2 & $91-137$ & 120 & 46 & 1.5 & 5.9 & 4.1 \\
\hline & 4 & $365-760$ & 413 & 395 & 1.5 & 1.8 & 10.7 \\
\hline & 5 & $760-916$ & 838 & 156 & 1.5 & 1.9 & 4.5 \\
\hline
\end{tabular}

aSample depth is measured from the ground surface.

bHorizon inventory $=$ concentration $\left(10^{8} \mathrm{x}\right.$ atoms $\left./ \mathrm{g}\right) \mathrm{x}$ horizon thickness $(\mathrm{cm}) \mathrm{x}$ bulk density $\left(\mathrm{g} / \mathrm{cm}^{3}\right)$. 


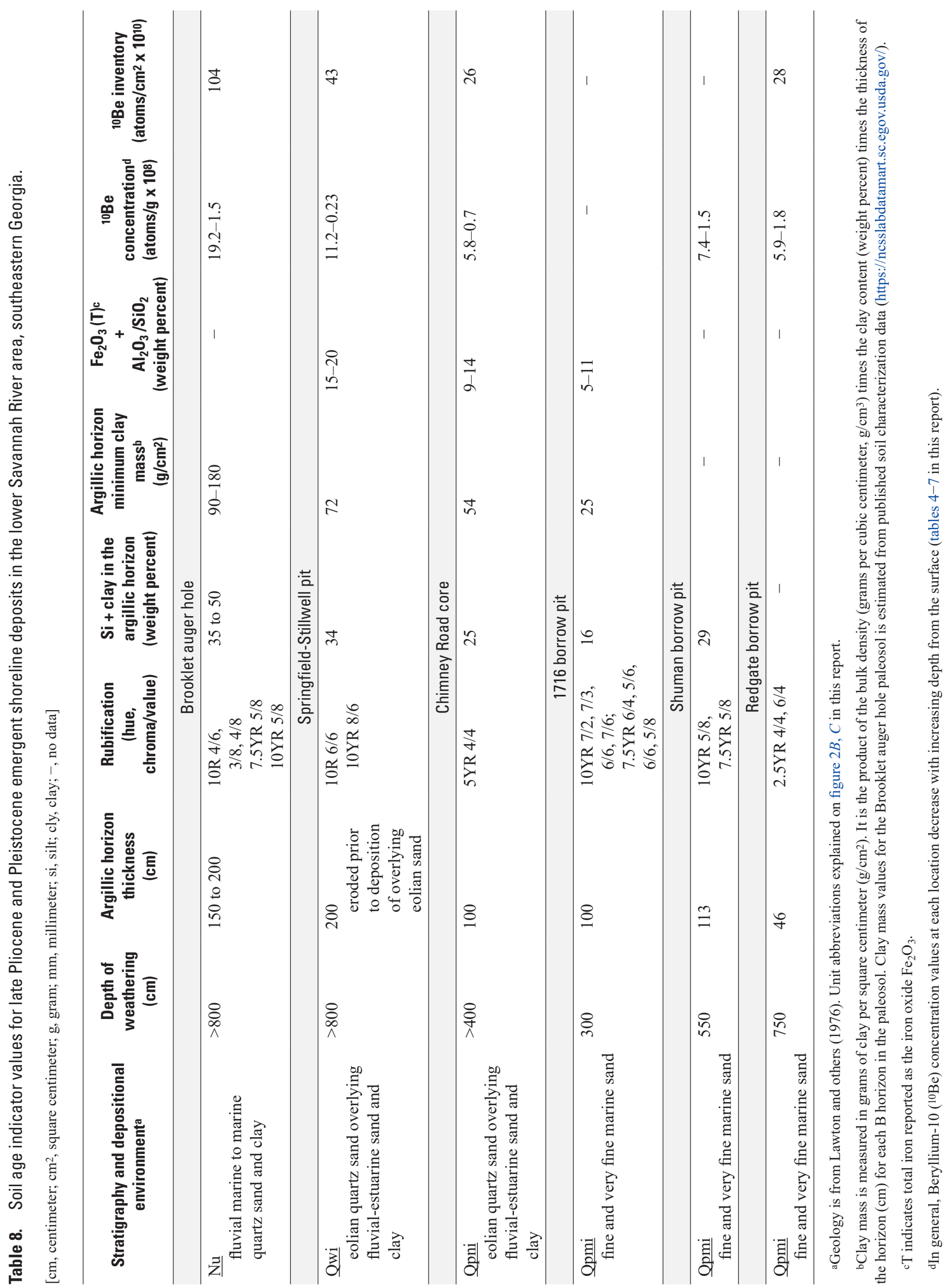


$\boldsymbol{A}$ Depth, in
meters

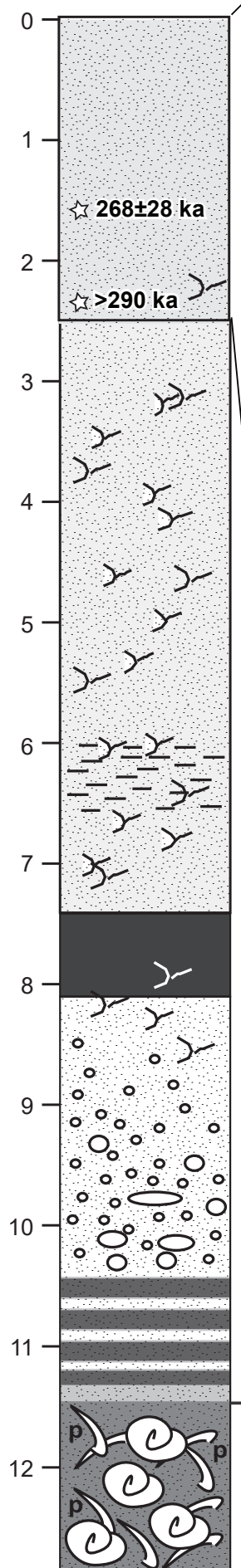

1716 BORROW PIT

Surface elevation $10.5-11.0$ meters, lat $32.0475^{\circ} \mathrm{N}$., long $81.1793^{\circ} \mathrm{W}$.

$\mathrm{E}, 0-80 \mathrm{~cm}$, fine sand, single grain, $10 \mathrm{YR} 5 / 3$ in surface $10 \mathrm{~cm}, 10 \mathrm{YR} 6 / 3-6 / 4$ at $20 \mathrm{~cm}$, 10YR $7 / 3-7 / 4$ at $40 \mathrm{~cm}, 10 \mathrm{YR} 7 / 3$ at $60 \mathrm{~cm}$

$\mathrm{B} 1 \mathrm{t}, 80-90 \mathrm{~cm}$, fine sand to loamy fine sand, single grain to very weak coarse subangular blocky, 10YR 7/2-7/3 with 10YR 6/6-7/6 mottles 2.5YR 4/4-6/4

$\mathrm{B} 12 \mathrm{t}, 90-110 \mathrm{~cm}$, fine sand to loamy fine sand, single grain to very weak coarse subanglar blocky, mottled 7.5YR6/4 and 5/6 with 5YR 4/6 firm masses $(\leq 0.64 \mathrm{~cm})$

B21t, $110-130 \mathrm{~cm}$, fine sand to loamy fine sand, massive breaking to weak subangular blocky and single grain, slightly brittle, 7.5YR 5/8 and 6/6

B22t, 130-160 cm, loamy fine sand, massive breaking to weak subangular blocky and single grain very slightly brittle, 7.5YR 5/8 dominant with some 10YR 6/4

B3t, $160-180 \mathrm{~cm}$, loamy fine sand, massive breaking to weak coarse subangular blocky, 10YR 6/6 and 7.5YR 5/8 mottled,

$\mathrm{BC}, 180-240 \mathrm{~cm}$, loamy fine sand, massive breaking to very weak and weak coarse subangular blocky, 10YR 6/6 and 7.5YR 6/6, 5/8, with clay-filled burrows and root casts, 5 YR $4 / 8$

C, $240 \mathrm{~cm}+$, fine sand, single grain, 10YR 8/8-7/8, manganese and charcoal blebs $\leq 2.54 \mathrm{~cm}$ diameter

Ophiomorpha burrows, without distinct casing of sand balls

Numerous, large, 2.5-4.0-cm diameter Ophiomorpha burrows with sand-ball casing, many occurring in clusters

Black, sticky, clay with few sand lenses; with large cypress logs and and in-place tree stumps

Predominantly quartz sand with numerous well-rounded 2.0-3.0-cm-diameter quartz pebbles and cobbles with few Ophiomorpha burrows

Very-fine, fine, and medium predominantly quartz sand-supported gravels; $>2 \mathrm{~mm}$ fraction is predominantly pebble size, but cobbles are numerous (long axis $\leq 8.0 \mathrm{~cm}$ )

Black, laminated clay and silt with very-thin interbeds of very-well sorted 5YR 8/1 to 5 YR 7/1-7/2 very-fine quartz sand; typical assemblages of southeastern Atlantic Coastal Plain interglacial pollen, dinoflagellates, and forams (tests); thickness varies from few centimeters to several meters

Silica- and phosphate-cemented, shell hash and near-shore marine sand; numerous phosphate pellets and carbon- and wood pieces, normal salinity, shells (broken and whole), sharks teeth, bone (including some vertebrae), pebbles (predominantly quartz). Shells include Carolina pecten eboreus, Cardita arata, and Mercenaria mercenaria

The $>290$ ka sample location is $\sim 848 m$ north-northeast across pit from the $268 \pm 28$ ka sample location) EXPLANATION

P Sand and small pebble-size phosphate and (or) somewhat phosphatic cement

Figure 6. Lithostratigraphy, general pedologic description, and optically stimulated luminescence (OSL) ages for Pamlico barrier deposits (Qpmi on fig. 2A,B) described and sampled in borrow pit exposures, Chatham County, Georgia. $A, 1716$ pit; $B$, Redgate pit; and $C$, Shuman pit on figure 2B. OSL data for the 1716 pit samples are in table 3. ${ }^{10} \mathrm{BePRT}$ data for Redgate and Shuman profiles are included in tables 6 and 7. $\mathrm{m}$, meter; $\mathrm{cm}$, centimeters; mm, millimeters; $\mathrm{ka}$, age in thousands of years. 
B

Depth,
in meters

in meters

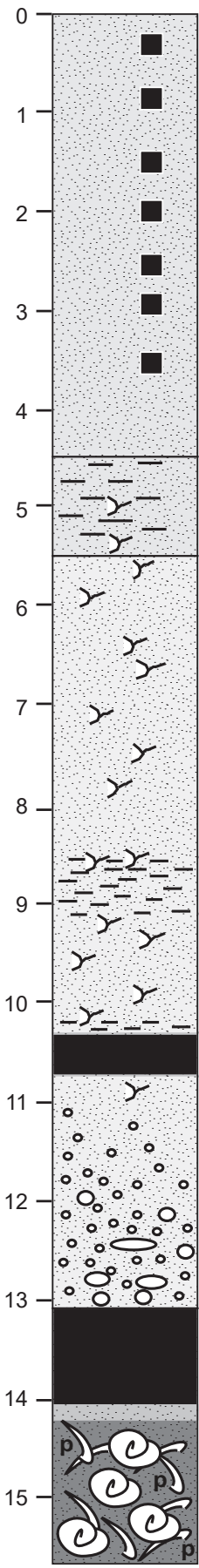

SHUMAN BORROW PIT

Surface elevation, $9.0-10.5$ meters; lat $32.0533^{\circ} \mathrm{N}$., long $81.1600^{\circ} \mathrm{W}$.

0-50 cm, E1, very-well sorted, fine sand; single grain; 10YR 7/3

$50-120 \mathrm{~cm}$, E2, very-well sorted, fine sand; single grain;10YR 7/2 -7/3

$120-170 \mathrm{~cm}$, EB, very-well sorted fine sand; mix of 10YR 6/4

and $6 / 6$ matrix with numerous 5YR $4 / 4-4 / 6$ and 10YR 5/8 mottles

$170-210 \mathrm{~cm}$, Bt1, sandy clay loam, 10YR 5/8, with faint indistinct mottles of 5 YR 5/8

(yellowish red) in upper half of horizon and distinct firm 2.5YR 4/6 (red) mottles in

lower half of horizon. The 2.5 YR 4/6 mottles grade into the Bt2 horizon

$210-283 \mathrm{~cm}$, Bt2, sandy clay loam, completely mottled, 10YR 6/2, 2.5YR 3/8-4/8,

$5 Y R 5 / 8$, and 7.5 YR $5 / 8$

283-313 cm, BC, fine sandy loam, completely mottled, 5YR 5/8 and 7.5YR 5/8 with nearvertical 0.3-2.0-cm-wide channels of 10YR 6/2 and 10YR 8/1

$313-398 \mathrm{~cm}, \mathrm{CB}$, massive, loamy fine sand grading to fine sand near base of horizon; $7.5 Y R 5 / 8$ mottles with indistinct borders throughout. Red mottles are similar to those in upper horizons in that they have a $2.5 \mathrm{YR} 4 / 8$ core with a surrounding 10YR 6/8, 7.5 YR $5 / 8$ and 2.5 YR $4 / 8$ surrounded by 10 YR $6 / 8$

$398-450 \mathrm{~cm}, \mathrm{C}$, massive loamy fine sand; mottled throughout, $7.5 \mathrm{YR} 5 / 8$ and 2.5YR 4/8 surrounded by 10 YR $6 / 8$

450-550 cm, C (weathered), 7.5YR 5/8, well-sorted very-fine and fine

quartz sand with very-thin and thin clay laminae, flasers, and some wavy beds of clay, common Ophiomorpha burrows.

5YR 8/1-8/3 (white to pink), well-sorted, fine and very-fine quartz sand with 1-3 weight percent heavies (5-7 percent from 5-6-m depth); Ophiomorpha burrows throughout

10YR 7/6-7/8 (yellow) and 6/8, bioturbated, fine and very-fine quartz sand; with 1-3 weight percent heavies

APPROXIMATE

PRESENT MEAN SEA LEVEL

Black, laminated clay, silt and sand (see description for clay between 13 and $14 \mathrm{~m}$ )

5YR $7 / 4$ to $6 / 8$ (reddish yellow), predominantly fluvial, very-fine, fine, and medium, sand and gravel; few Ophiomorpha burrows in uppermost $0.5 \mathrm{~m}$; indistinct bedding; >2-mm fraction is predominantly pebbles, with numerous cobbles (long-axis $\leq 8.0 \mathrm{~cm}$ )

Black, estuarine, laminated clay and silt with very-thin interbeds of very-well sorted 5YR 8/1 to 5YR 7/1-7/2 very-fine quartz sand; typical assemblages of southeastern Atlantic Coastal Plain interglacial pollen, dinoflagellates, and forams (tests); thickness varies from few centimeters to several meters

Pliocene Duplin/Raysor Formation, silica- and phosphate-cemented, shell hash and near-shore marine sand; numerous phosphate pellets and carbon- and wood pieces, normal salinity, shells (broken and whole), sharks teeth, bone (including some vertebrae), pebbles (predominantly quartz). Shells incude Carolina pecteneboreus, Cardita arata, and Mercenaria mercenaria

\section{EXPLANATION}

Sample for meteoric ${ }^{10} \mathrm{Be}$ isotope analysis Break in scale

p Sand and small pebble-size phosphate and (or) somewhat phosphatic cement

Figure 6.-Continued 
C REDGATE BORROW PIT

Depth, $\quad$ Surface elevation, 9.5-10.5 meters; lat $32.0417^{\circ} \mathrm{N}$., long $81.1667^{\circ} \mathrm{W}$. in meters

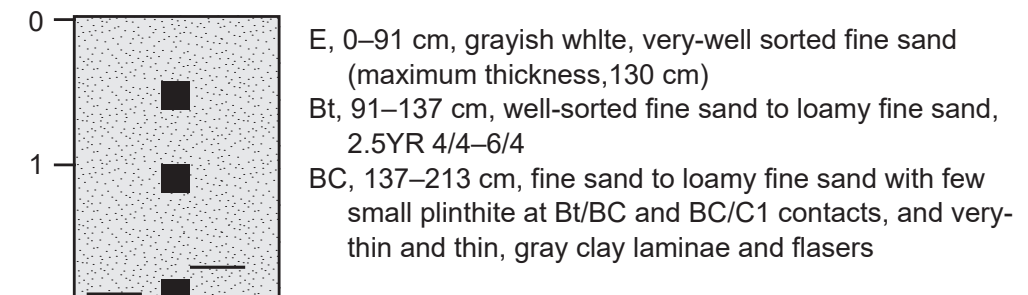

Few Ophiomorpha burrows present in E, Bt, and BC

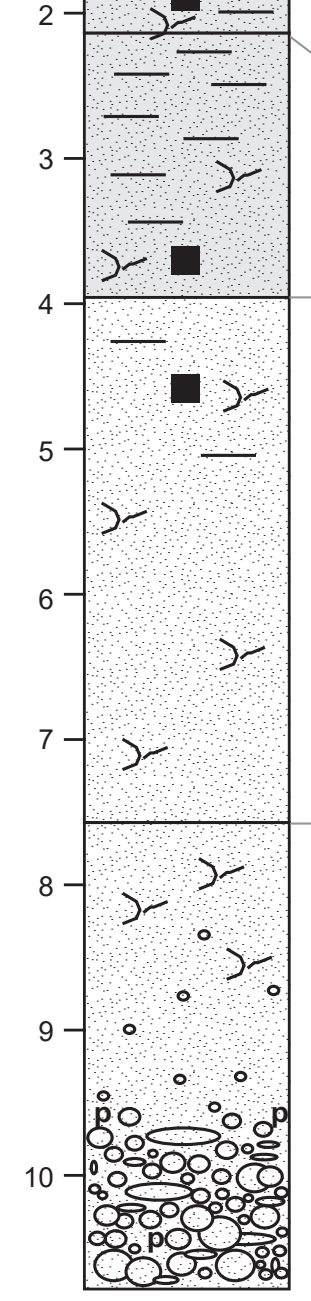

C1, 213-396 cm, fine and very-fine sand, $5 Y R$ 6/8 with

7.5 YR $6 / 6$ to 5 YR $7 / 3-7 / 4$ very-thin and thin clay laminae and flasers, and Ophiomorpha burrows, without distinct casing of sand balls

C2, 396-760 cm, fine sand, 5YR 8/1-8/3, 1-5 weight percent heavies and common, large, 2.5-4.0-cm diameter, Ophiomorpha burrows with sand-ball casing

C3, 760-930 cm, very-fine and fine, well-sorted, predominantly quartz sand with numerous wellrounded 2.0-3.0-cm-diameter quartz pebbles and cobbles with few Ophiomorpha burrows

Very-fine, fine, and medium sand-supported gravels;

$>2 \mathrm{~mm}$ fraction is predominantly pebble size, but cobbles are numerous (long axis $\leq 8.0 \mathrm{~cm}$ ); few phosphate pebbles, partly indurated near base of exposure with silica and phosphate cement

\section{EXPLANATION}

Sample for meteoric ${ }^{10} \mathrm{Be}$ isotope analysis $\checkmark$ Break in scale

p Sand and small pebble-size phosphate and (or) somewhat phosphatic cement

Figure 6.-Continued 


\section{Princess Anne Shoreline Complex (Qpai and Opam)}

Princess Anne Shoreline Complex deposits (Qpai and Qpam) occur seaward of the main Pamlico barrier as a narrow flat plain and as detached islands. The stratigraphy for deposits of this complex as seen in the Chatham 1 core on the Isle of Hope (CH-1 on fig. $2 A, D)$ is shown on figure 7. Deposits of this complex have been dated by AAR and OSL analyses (tables 1 and 2). AAR analyses of molluscan fauna in deposits near present sea level that occur on the flat plain seaward of the main Pamlico barrier indicate a middle Pleistocene age between $450 \mathrm{ka}$ to $250 \mathrm{ka}$ (FCGC on fig. 2B; fig. 19 in Muhs and others, 2003; Markewich and others, 2013). Turck and Alexander (2013) reported 45 to $43 \mathrm{ka}{ }^{14} \mathrm{C}$ ages and a $62.5 \mathrm{ka}$ OSL age for stratigraphically younger marine sand from a locality just west of the FCGC locality (table 1). No numerical ages are available for $\mathrm{CH}-1$ deposits, but OSL ages are available for marine deposits at other localities on the Isle of Hope (GAW20, >220 ka; GAW21, 9.3 \pm 0.44 ka; and GAW22, $35.7 \pm 2.7 \mathrm{ka}$ in tables 1 and 3). The combined AAR, ${ }^{14} \mathrm{C}$ and OSL ages, and the position of the Princess Anne Shoreline Complex seaward of the 300 to 200 ka Pamlico Shoreline Complex, indicate that the Princess Anne Shoreline Complex probably is older than 200,000 years and was deposited during multiple periods of deposition in the middle and late Pleistocene.

\section{Silver Bluff Shoreline Complex (Qsbi and Qsbm)}

Silver Bluff Shoreline Complex barrier island deposits (Qsbi) compose the Wilmington and Skidaway Islands, which are surrounded by marsh-lagoonal deposits of the Holocene Shoreline Complex. The stratigraphy for deposits of this complex as seen in the Chatham 18 core on Skidaway Island (CH-18 on fig. $2 A, D$ ) is shown in figure 8 . No numerical ages are available for deposits in this core, but U-series, OSL, and radiocarbon ages are available for marine deposits at other localities on Skidaway Island. Wehmiller and others (2004) reported four $85 \mathrm{ka}$ to $80 \mathrm{ka} \mathrm{U}$-series ages for coral from a fossiliferous near-shore marine deposit at the Jones borrow pit locality (J on fig. 2D) on Skidaway Island. These ages support the findings of Ludwig and others (1996) for shallow submerged reefs in the area of the Florida Keys and for 1-2-meter-emergent marine deposits in Bermuda.

At the Jones borrow pit locality on Skidaway Island, two marine sand units overlie the 85 to $80 \mathrm{ka}$ deposit. A paleochannel containing peat clasts separates the two sand units. Booth and others (2003) reported a 37 to $36 \mathrm{ka}{ }^{14} \mathrm{C}$ age for terrestrial plant stems incorporated into the peat clasts. These ages for the basal coral-bearing marine unit and the overlying channel deposit indicate an age between 85 and $36 \mathrm{ka}$ for the lower marine sand unit and a younger than $36 \mathrm{ka}$ age for the surface marine sand. Markewich and others (2013) reported OSL ages for marine sand exposed in low bluffs on the north and west edges of Skidaway Island (106 $\pm 4.7 \mathrm{ka}$, GAW23; $117 \pm 11.3 \mathrm{ka}$, GAW19, respectively, fig. 2D, tables 1 and 3). Hoyt and others (1968) reported a 42.7 \pm 3.7 (infinite) radiocarbon age for a near-surface shell from Wilmington Island (table 1), which they cautioned might be at the limit of radiocarbon dating. They also reported numerous other radiocarbon ages between 50 to $20 \mathrm{ka}$ for shells in near-shore marine deposits on the GA coast south of the LSRA. Turck and Alexander (2013, their table 7.2) reported 56 to $35 \mathrm{ka}$ OSL ages for deposits of marine sand on the southeast and southwest arms of Skidaway Island (SK05B and SK06B; fig. 2D, table 1). The combined age data for terrestrial and marine deposits indicate that Silver Bluff Shoreline Complex deposits record intermittent periods of late Pleistocene marine deposition and terrestrial processes.

\section{Holocene Shoreline Complex (Qhi and Qhm)}

Holocene Shoreline Complex fluvial marine and marine deposits (Qhm) surround Silver Bluff barrier island deposits (Qsbi) and extend up the major river valleys (fig. 2B). OSL ages for deposits landward of Skidaway Island are 35.1 $\pm 2.2 \mathrm{ka}$ (GAW40, Oatland Island) and 28.8 $\pm 1.7 \mathrm{ka}$ (GAW41, Fort McAllister). Localities of these dated deposits are shown on figure $2 B$. Sample ages and dating methods are in table 1 . Analytical data for the OSL ages are in table 3 . Swezey and others (2018) reported a $4.3 \mathrm{ka}$ age for an oyster shell in the marine sand at the top of the Cockspur Island core just landward of Tybee Island (fig. $2 B$, specific location not shown). Turck and Alexander (2013) reported several OSL and ${ }^{14} \mathrm{C}$ ages for barrier island and marsh and lagoonal deposits between Skidaway Island and Wassaw Island (islands shown on fig. $2 B$, specific localities not shown). These ages are one to two orders of magnitude younger than ages for Silver Bluff Shoreline Complex deposits and for the Holocene Shoreline Complex deposits at Fort McAllister and Oatland Islands. Two of those ages (OSL010, 0.389 $\pm 0.06 \mathrm{ka}$; OSL011, $0.135 \pm 0.02 \mathrm{ka}$ ) are included in table 1 for comparison to Silver Bluff and other Holocene Shoreline Complex ages.

\section{Details for Previously Unpublished Age and Stratigraphic Data}

This section presents previously unpublished stratigraphy and age data for several localities in the LSRA. Locations referred to are shown on figure $2 A-D$. Lithostratigraphic descriptions of exposures and cores are in figures 4-8. Depths for samples taken at each locality, mostly for age determinations, are indicated on each figure. Numerical ages are included in tables 1 and 2. Analytical data for these calculated ages, and for soil and weathering profile ages, are presented in tables 3-8. Chemical and particle size distribution data for selected deposits are in tables 9-17. For near-shore marine deposits in the LSRA, primary minerals in the $<0.063-\mathrm{mm}$ particle size are quartz, kaolinite, hydroxyinterlayered vermiculite, and gibbsite (Markewich and others, 2013). 


\section{CHATHAM-1 CORE}

Georgia Geological Survey core number GGS 1164 or 535 (both labels are used in Huddlestun, 1988), Surface elevation 3.66 meters; lat $31.9899^{\circ} \mathrm{N}$., long $81.0476^{\circ} \mathrm{W}$.

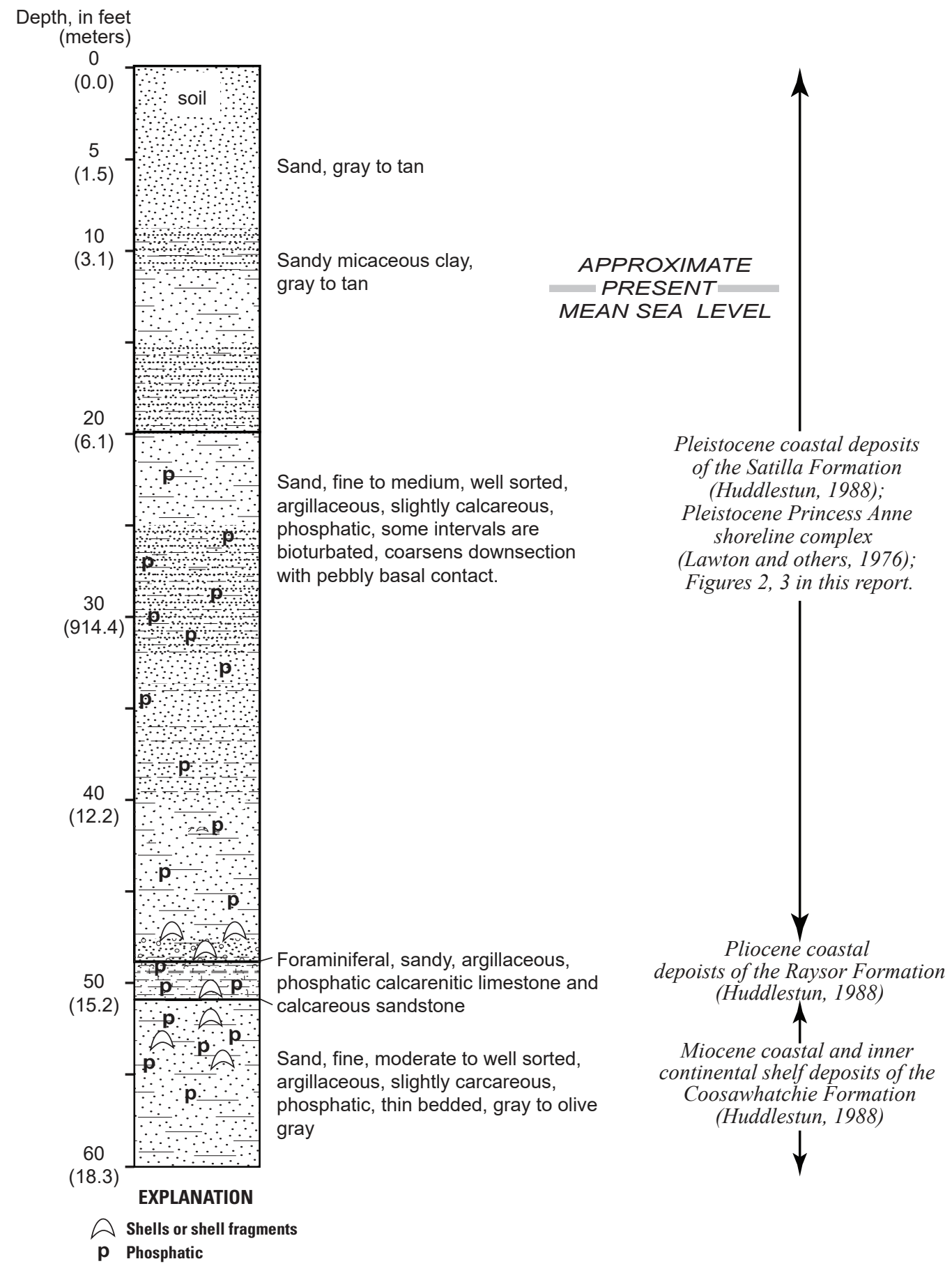

* Furlow (1969, p. 31) places the Duplin/Raysor Formation contact with the overlying Pleistocene sediments at $69 \mathrm{ft}(21 \mathrm{~m})$ depth based on the percentage of phosphate in the sediments Core $(\mathrm{CH}-1)$ location on figure $2 \mathrm{D}$ in this report

Figure 7. Lithostratigraphy of the Chatham 1 core in Opam deposits on Isle of Hope, Chatham County, Georgia (CH-1 on fig. 2A, D). 
CHATHAM-18 CORE

Georgia Geological Suvey core number GGS 3639, Surface elevation 2.93 meters, lat $31.986^{\circ}$ N., long $81.019^{\prime}$ W.

$$
\text { Depth in }
$$

feet (meters)

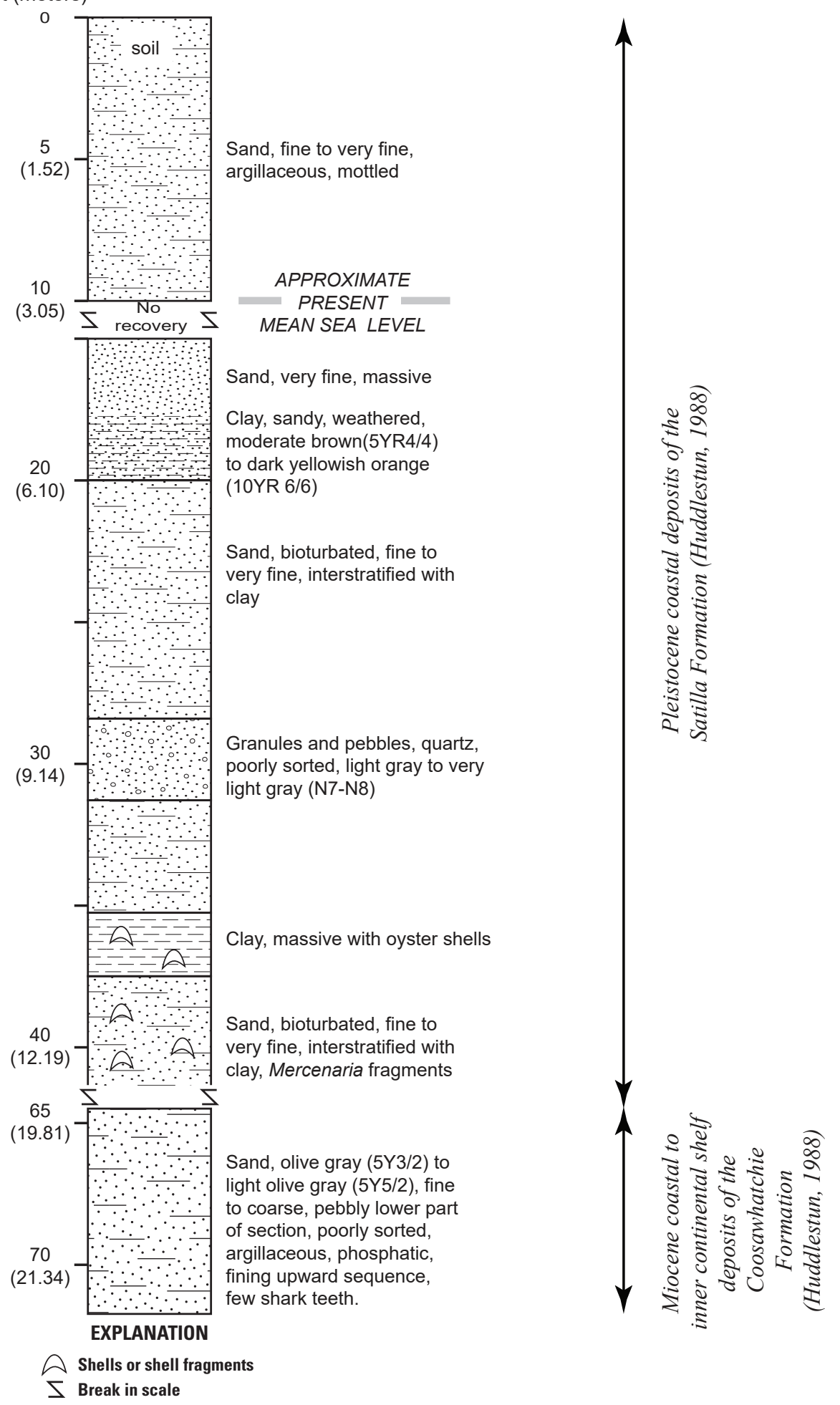

Figure 8. Lithostratigraphy of the Chatham 18 core in Qsbi deposits, Skidaway Island, Chatham County, Georgia $(\mathrm{CH}-18$ on figure $2 A, D)$. 


\section{Brooklet Auger Hole, Atop the Orangeburg Scarp}

The Brooklet auger hole (figs. $2 \mathrm{C}$ and 4 ) is located on a broad interfluve atop the Orangeburg Scarp and is the most landward and topographically highest LSRA locality for which there are age data. The interfluve is underlain by a deeply weathered and pedogenically altered nearshore fluvial-marine to marine, fine and very fine quartz sand and clay ( $\mathrm{Nu}$ on fig. $2 \mathrm{C}$ ). Quartz is the primary silt and sand mineral (98 percent for a 300 -grain count) with a few percent rutile, zircon, and other opaque heavy minerals. Plinthites and other concretions/nodules are primarily quartz but also contain sesquioxides including gibbsite and hematite (Gallaher and others, 1973). Diagnostic soil and weathering properties for the Brooklet auger hole deposit differ markedly from the same indicator values for fluvialmarine to marine quartz sand and clay deposits seaward of the Scarp (Qwi, Qpni, Qpmi in table 8). Soil and weathering parameters measured for this deposit are an estimated 30 to 40 weight percent clay in the $\mathrm{B}$ horizons, a total thickness of $1.5 \mathrm{~m}$ for the B horizon, $\mathrm{a}>2.2-\mathrm{m}$-thick solum (A and B horizons), an 8-m depth of weathering, and high chroma 10R and 5YR colors throughout the profile (table 8). Using the criteria of Markewich and others (1989) and Markewich and Pavich (1991), each parameter indicates a minimum age no younger than early middle Pleistocene. A calculated clay mass value of 75 to $110 \mathrm{~g} / \mathrm{cm}^{2}$ and the maximum ${ }^{10} \mathrm{Be}$ concentrations and inventory values for the Brooklet auger hole soil agree with this estimated early middle Pleistocene age. The ${ }^{10} \mathrm{Be}$ concentration profile (figs. $2 C$, 4; table 4 ) has values that are significantly higher than values for paleosols developed in barrier sand seaward of the Scarp (table 8). The maximum ${ }^{10} \mathrm{Be}$ concentration of $19.2 \times 10^{8}$ atoms/g in the Brooklet auger hole deposit is 1.7 times greater than the $11.2 \times 10^{8}$ atoms/g maximum for the Wicomico (Qwi) deposit (Markewich and others, 2013), 3.3 times greater than for the Penholoway (Qpni) deposit, and 2.7 to 3.3 times greater than for the Pamlico (Qpmi) deposit. The total Brooklet ${ }^{10} \mathrm{Be}$ inventory $\left(104{ }^{10} \mathrm{Be}\right.$ atoms $\left./ \mathrm{cm}^{2} \times 10^{10}\right)$ is four times as great as the Pamlico deposit inventories (25 to $29{ }^{10} \mathrm{Be} \times 10^{10}$ atoms/ $\mathrm{cm}^{2}$ ). Inventory data are in tables 4, 6-8. With correction for radioactive decay $\left(\mathrm{t}_{1 / 2}=1.39 \times 10^{6} \mathrm{yr}\right.$; Korschinek and others, 2010), the minimum ${ }^{10}$ BePRT age for the Brooklet auger hole deposit atop the Scarp is $1 \mathrm{Ma}$ to $700 \mathrm{ka}$. If the upper $0.9 \mathrm{~m}$ of the Brooklet profile had been sampled (fig. 4), the inventory value, and possibly the maximum concentration value, would be higher, indicating an even older minimum age. The position of the Brooklet auger hole deposit atop the Scarp and landward of the late Pliocene to early Pleistocene deposits at the Scarp base (PPs on fig. 2A,C) indicates a deposit age no younger that early late Pliocene.

\section{Chimney Road Core, Penholoway Shoreline Complex}

The 16-m-deep Chimney Road core is located near the northeastern end of the most seaward and topographically lowest (15 to $19 \mathrm{~m}$ ) ridge of the Penholoway Shoreline Complex (Qpni on fig. 2A, C; core location on fig. 2C). Deposits at the Chimney Road core location are a deltaic sequence of fluvial-estuarine, estuarine, and near-shoremarine/estuarine sand, silt, and clay overlain by 1 to $3 \mathrm{~m}$ of eolian sand (stratigraphy on fig. 5). Particle-size distribution data are in table 9. Major element oxide chemistry is in table 10. Particle size and chemistry reflect the quartz-rich eolian sand and the weathered and pedogenically altered clay-rich fluvial/near-shore marine coastal deposits. Soil and weathering indicator values for the fluvial-marine deposit, such as the dominant 5YR 4/4 color and $1.2 \mathrm{~m}$ argillic horizon thickness for the paleosol B horizon, indicate a several hundred thousand year old age (table 8 ). This age agrees with the $174.9 \mathrm{ka}{ }^{10}$ BePRT age (table 5) for the same deposit. Samples of the overlying 1.5-m-thick eolian-sand were dated by both ${ }^{10} \mathrm{BePRT}$ and OSL analyses. ${ }^{10} \mathrm{Be}$ inventory data for the eolian sand in the uppermost $1.5 \mathrm{~m}$ of core indicate a minimum residence time of $27 \mathrm{ka}$ (table 5). Eolian sand at 0.91-m depth in a nearby hand-dug pit (about $25 \mathrm{~m}$ northwest of the core) has an OSL age of $88.9 \pm 3.77 \mathrm{ka}$ (GAW38). The combined OSL and ${ }^{10}$ BePRT ages for the Chimney Road core and the nearby hand dug pit indicate a minimum age of about $260 \mathrm{ka}$ for the Penholoway barrier deposit. Markewich and others (2013) reported a $129 \pm 7 \mathrm{ka}$ (GAW17) OSL eolian-sand age and a $>225 \mathrm{ka}$ (GAW34) barrier deposit age for these same strata at a locality just $350 \mathrm{~m}$ north of the Chimney Road core. The range in OSL and ${ }^{10} \mathrm{BePRT}$ ages presented in this report and in Markewich and others (2013) indicate a minimum age of about $225 \mathrm{ka}$ and an approximate age range of 360 to $260 \mathrm{ka}$ for this youngest barrier of the Penholoway Shoreline Complex. Age data are included in tables 2 and 3; locations are shown as stars 17,34 , and 38 on figure $2 C$. 


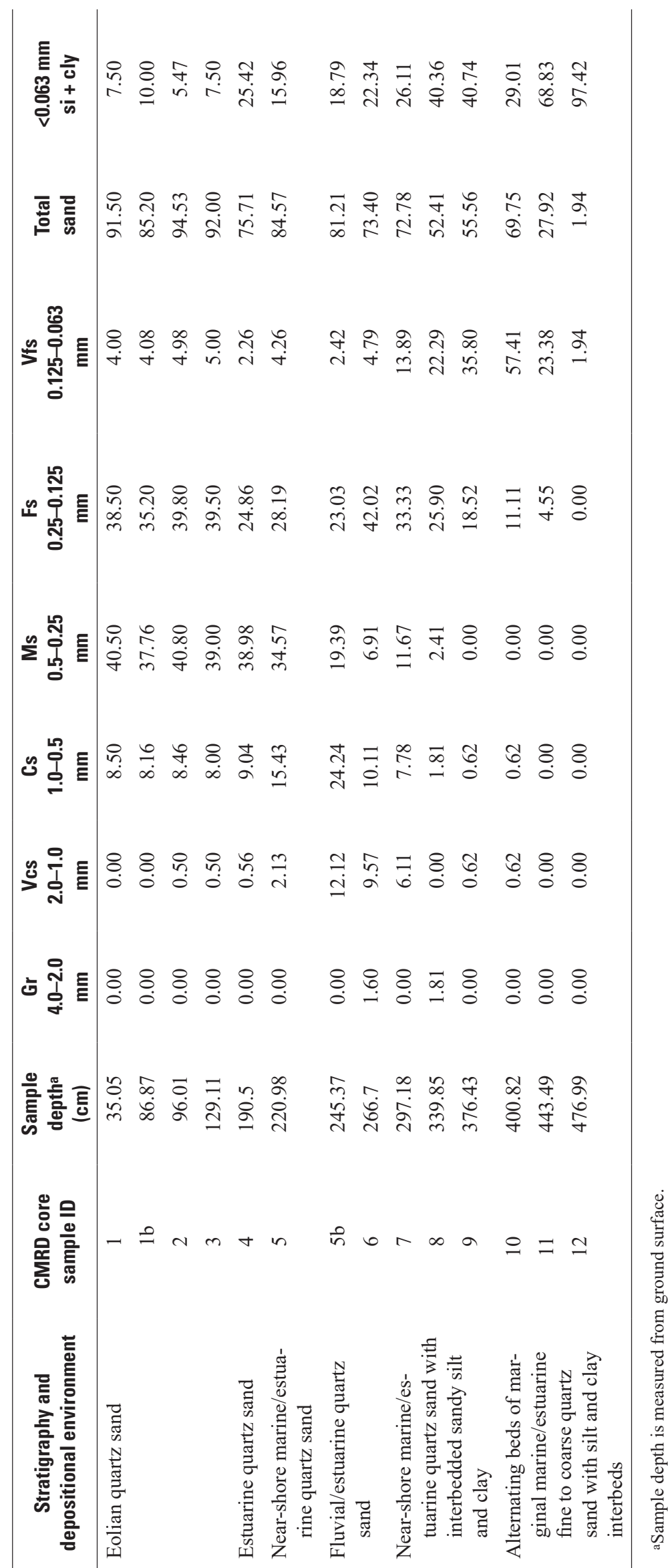




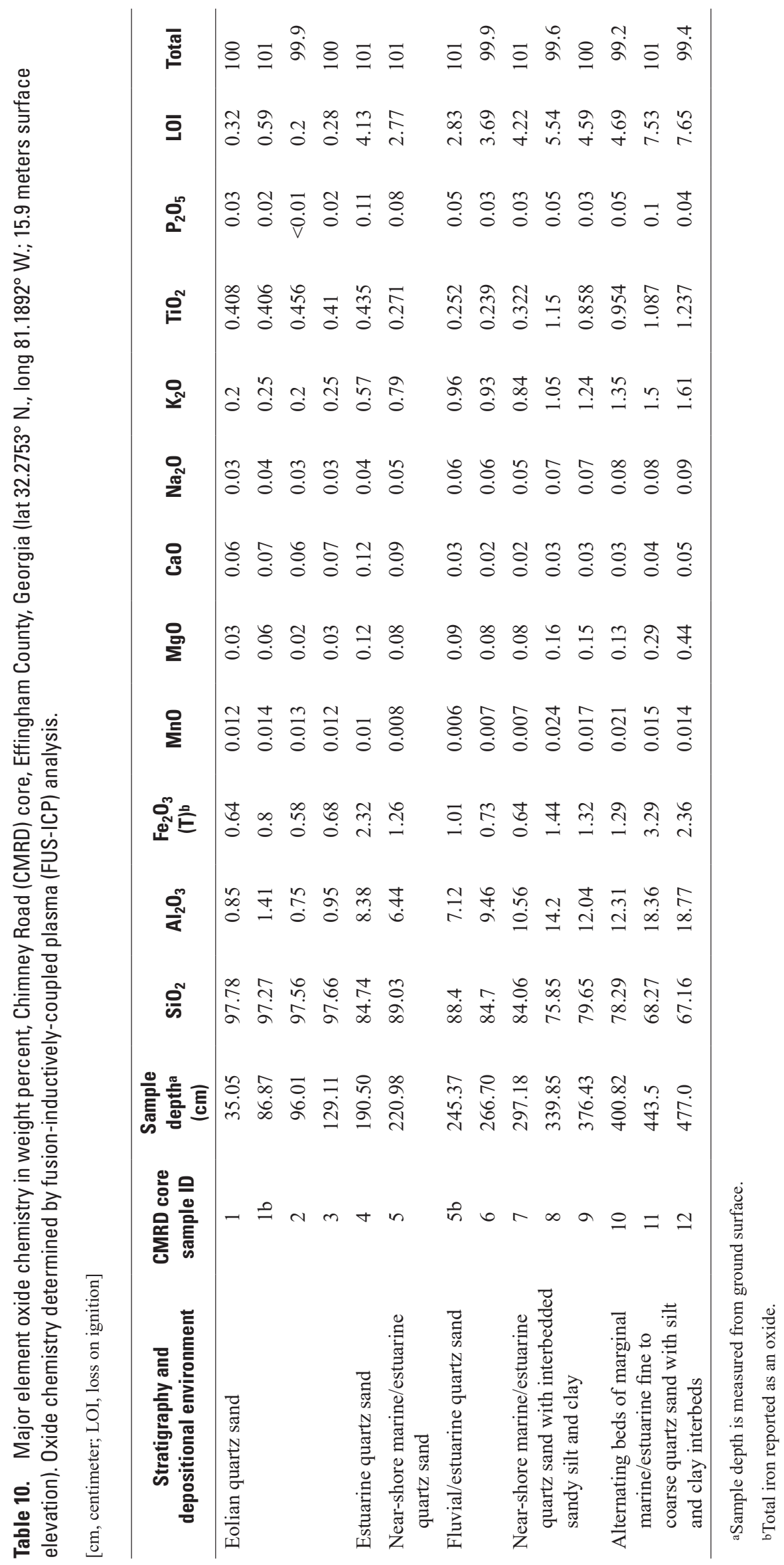




\section{6, Shuman, and Redgate Borrow Pits, Pamlico Shoreline Complex}

Three large, no-longer-accessible, commercial borrow pits (1716, Shuman, and Redgate), located on one of the broad barrier flats of the Pamlico Shoreline Complex (Qpmi), exposed a 7- to 12-m-thick transgressive sequence of fluvial, fluvial-marine, and barrier/beach-ridge deposits (location on fig. $2 B$; stratigraphy in fig. $6 A-C$ ). Compositionally, the upper $5 \mathrm{~m}$ of Pamlico shoreline deposits consist of fine, rounded to subrounded, quartz barrier sand with very abundant Ophiomorpha. Thin clay beds and flasers are more numerous below $5 \mathrm{~m}$ depth, but Ophiomorpha generally are present in each sand bed. Discontinuous cypress swamp and fluvial gravel deposits occur beneath the marine sand in the 1716 and Shuman pits. The black silty, clayey sand to sandy clay swamp deposits occur at 7-8 m depth in the 1716 pit (fig. $6 A$ ) and $10-11 \mathrm{~m}$ depth in the Shuman pit (fig. $6 B$ ). Cypress logs too old to date by ${ }^{14} \mathrm{C}$ occur in these swamp deposits. Sedimentological and chemical analyses for the 1716 and Shuman borrow pits are included in tables 11-17. Fossiliferous late Pliocene Duplin/Raysor Formation deposits were exposed in, and (or) were present as dredge piles at the base of these pits.

${ }^{10} \mathrm{BePRT}$ ages were determined for the soil and weathering profiles of the Pamlico Shoreline Complex marine sand exposed in the Shuman and Redgate borrow pits (fig. 6B, C). OSL ages were determined for the Pamlico Shoreline Complex marine sand exposed in the 1716 borrow pit (fig. $6 \mathrm{~A} ; 1716 \mathrm{~A}$ and $1716 \mathrm{~B}$ in tables 2 and 3). The Redgate soil and weathering profile was sampled to a depth of $898 \mathrm{~cm}$; the Shuman profile was sampled to a depth of $355 \mathrm{~cm}$. The minimum ${ }^{10} \mathrm{BePRT}$ age for the marine sand at the Redgate borrow pit is $231 \mathrm{ka}$ (table 7). For the Shuman borrow pit, the minimum ${ }^{10} \mathrm{BePRT}$ age is $163 \mathrm{ka}$ (table 6). This younger ${ }^{10} \mathrm{BePRT}$ age for the Shuman soil and weathering profile is primarily due to the shallower depth of sampling. The ${ }^{10} \mathrm{Be}$ concentration values for the Redgate and Shuman soil and weathering profiles are similar. ${ }^{10} \mathrm{Be}$ concentration values for samples below $4 \mathrm{~m}$ depth in the Redgate pit are $1.8 \times 10^{8}$ atoms $/ \mathrm{g}$ at $413 \mathrm{~cm}$ depth and $1.9 \times 10^{8}$ atoms $/ \mathrm{g}$ at $898 \mathrm{~cm}$ depth. Appending these values to the base of the Shuman profile makes the soil and weathering profiles at the two sites comparable $\left({ }^{10} \mathrm{Be}\right.$ horizon inventories between $28-29{ }^{10} \mathrm{Be}$ atoms $/ \mathrm{cm}^{2} \times 10^{10}$, indicating a $230 \mathrm{ka}{ }^{10} \mathrm{BePRT}$ minimum age). OSL ages of $267 \pm 28 \mathrm{ka}$ and $>290$ ka from the 1716 borrow pit (tables 2 and 3) generally agree with the $231 \mathrm{ka}{ }^{10} \mathrm{BePRT}$ age for the Redgate profile.

Markewich and others (2013) reported a $>220$ ka OSL age (GAW33) for deposits they referred to as Savannah River terrace fluvial/estuarine silty sand. On the 1:500,000 scale of the 1976 geologic map by Lawton and others this sample location is near the contact between Talbot and Pamlico marsh-lagoonal facies deposits (fig. 2C). The $>220 \mathrm{ka} \mathrm{OSL}$ age for Qtm/Qpmm deposits at this locality agrees with ages for the Pamlico barrier marine sand (Qpmi) exposed in the 1716, Shuman, and Redgate borrow pits. The combined OSL and ${ }^{10} \mathrm{BePRT}$ data for the Qpmi and Qpmm deposits indicate a minimum age between 231 and $163 \mathrm{ka}$, and an age range of $>290$ to about $200 \mathrm{ka}$ for the Pamlico Shoreline Complex. Using the criteria of Markewich and others (1989) and Markewich and Pavich (1991), the soil indicator values for the Pamlico barrier deposits exposed at these three localities also indicate an age range of 300 to $200 \mathrm{ka}$ (table 8).

\section{Localities Seaward of the Pamlico Shoreline Complex}

A few unpublished lithostratigraphic descriptions and OSL ages are now available for Princesses Anne and Silver Bluff deposits in the LSRA. Core and sample locations are on figure 2D. The lithostratigraphy of Princess Anne (Qpam) and older deposits in the Chatham 1 core on Isle of Hope is shown on figure 7. The lithostratigraphy of Silver Bluff (Qsbi) and older deposits in the Chatham 18 core on Skidaway Island is shown on figure 8 . Lithostratigraphy for the cores are from Furlow (1969), Huddlestun (1988) and P.F. Huddlestun (oral and written commun., 2010). Previously unpublished OSL ages for marine deposits on the Isle of Hope were $>220 \mathrm{ka}$, $35.7 \pm 2.7 \mathrm{ka}$, and $9.3 \pm 0.44 \mathrm{ka}$, (GAW20, 21, and 22 on fig. $2 D$ and in tables 1 and 3) and show a greater than 200,000 year age range for deposits mapped as Princess Anne. 


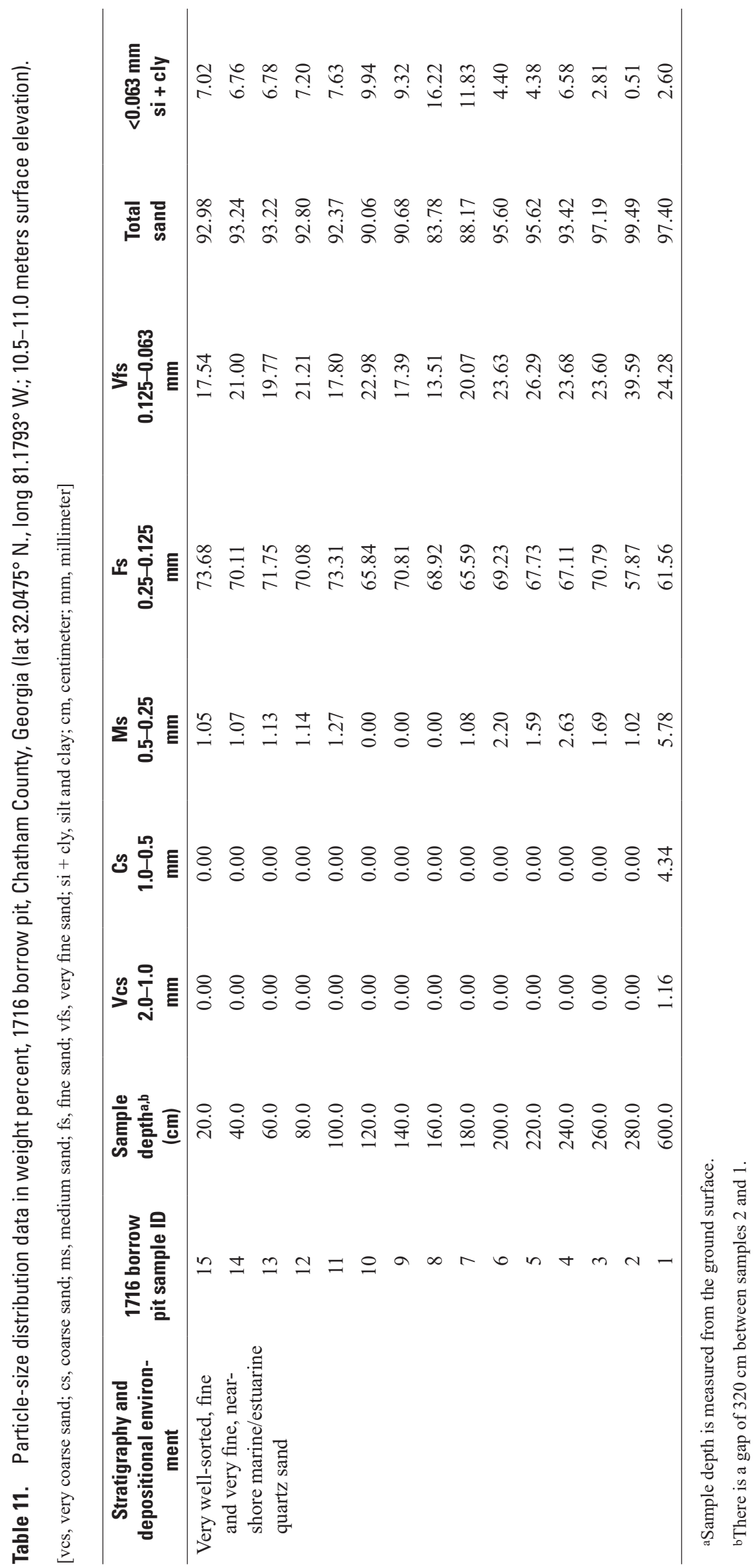




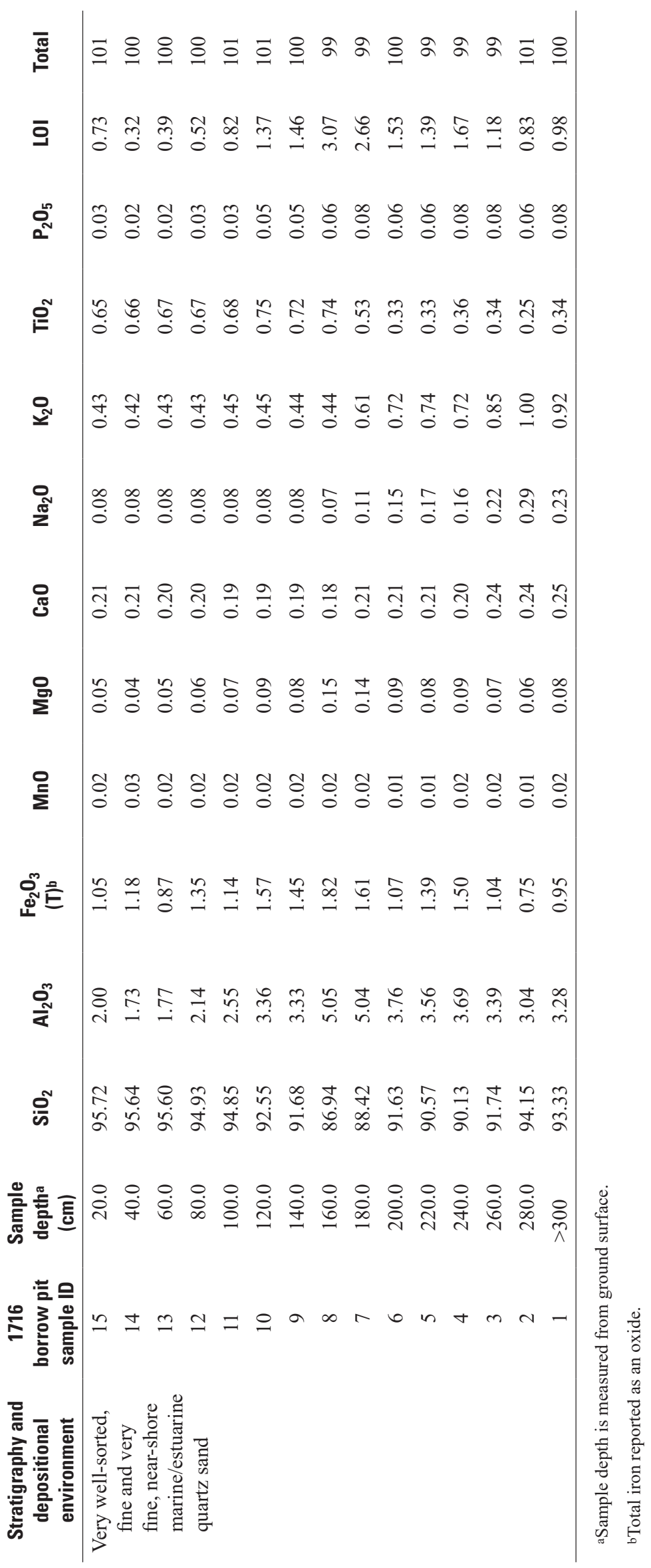


Table 13. Minor element chemistry in parts per million (ppm) for samples from the 1716 borrow pit, Chatham County, Georgia (lat $32.0475^{\circ} \mathrm{N}$., long $81.1793^{\circ} \mathrm{W}$.; $10.5-11$ meters surface elevation). Minor element chemistry determined by fusion-inductively-coupled plasma (FUS-ICP) analysis or fusion mass spectrometry. For all samples, $\mathrm{Be}, \mathrm{Ni}, \mathrm{Cu}, \mathrm{Zn}, \mathrm{As}$, and $\mathrm{In}$ have values below detection limits.

\begin{tabular}{ccccccccccccccr}
\hline $\begin{array}{c}\text { Stratigraphy and } \\
\text { depositional } \\
\text { environment }\end{array}$ & $\begin{array}{c}\mathbf{1 7 1 6} \\
\text { borrow pit } \\
\text { sample ID }\end{array}$ & $\begin{array}{c}\text { Sample } \\
\text { deptha } \\
\text { (centimeter) }\end{array}$ & Sc & $\mathbf{V}$ & $\mathbf{C r}$ & $\mathbf{C o}$ & $\mathbf{G a}$ & $\mathbf{G e}$ & $\mathbf{R b}$ & $\mathbf{S r}$ & $\mathbf{Y}$ & $\mathbf{Z r}$ & $\mathbf{N b}$ & Mo \\
\hline $\begin{array}{l}\text { Very well-sorted, } \\
\text { fine and very }\end{array}$ & 15 & 20.0 & 5 & 17 & 30 & 2 & 4 & 2 & 20 & 58 & 8 & 349 & 5 & $<2$ \\
fine, near-shore & 14 & 40.0 & 2 & 22 & 70 & 1 & 3 & 2 & 20 & 64 & 4 & 205 & 7 & 8 \\
marine/estuarine & 13 & 60.0 & 5 & 17 & 30 & 2 & 4 & 1 & 19 & 55 & 5 & 260 & 6 & $<2$ \\
quartz sand & 12 & 80.0 & 3 & 25 & 60 & 2 & 5 & 2 & 17 & 50 & 7 & 230 & 6 & 6 \\
& 11 & 100.0 & 5 & 18 & 30 & 2 & 5 & 2 & 18 & 48 & 6 & 234 & 5 & $<2$ \\
& 10 & 120.0 & 5 & 24 & 60 & 2 & 5 & 2 & 17 & 47 & 5 & 226 & 6 & 5 \\
& 9 & 140.0 & 4 & 27 & 30 & 3 & 7 & 2 & 17 & 50 & 7 & 327 & 8 & $<2$ \\
& 8 & 160.0 & 4 & 36 & 60 & 3 & 8 & 2 & 17 & 41 & 10 & 585 & 12 & 4 \\
& 7 & 180.0 & 6 & 37 & 60 & 2 & 5 & 2 & 14 & 33 & 12 & 661 & 13 & 6 \\
& 6 & 200.0 & 5 & 29 & 30 & 2 & 5 & 2 & 14 & 33 & 12 & 619 & 12 & $<2$ \\
& 5 & 220.0 & 5 & 30 & 60 & 2 & 4 & 2 & 14 & 30 & 11 & 623 & 12 & 6 \\
& 4 & 240.0 & 4 & 23 & 30 & 2 & 3 & 2 & 13 & 30 & 13 & 624 & 11 & $<2$ \\
& 3 & 260.0 & 4 & 25 & 50 & 1 & 3 & 1 & 12 & 30 & 11 & 618 & 11 & 5 \\
& 2 & 280.0 & 4 & 17 & 30 & 2 & 3 & 2 & 12 & 30 & 11 & 637 & 10 & $<2$ \\
& 1 & $>300$ & 4 & 20 & 30 & 2 & 3 & 2 & 12 & 30 & 11 & 594 & 10 & $<2$ \\
\hline
\end{tabular}

aSample depth is measured from the ground surface.

Table 14. Minor element chemistry in parts per million (ppm) for samples from the 1716 borrow pit, Chatham County, Georgia (lat $32.0475^{\circ} \mathrm{N}$., long $81.1793^{\circ} \mathrm{W}$.; $10.5-11$ meters surface elevation). Minor element chemistry determined by fusion-inductively-coupled plasma (FUS-ICP) analysis or fusion mass spectrometry. For all samples, $\mathrm{Be}, \mathrm{Ni}, \mathrm{Cu}, \mathrm{Zn}, \mathrm{As}$, and $\mathrm{In}$ have values below detection limits.

\begin{tabular}{|c|c|c|c|c|c|c|c|c|c|c|c|c|c|c|}
\hline $\begin{array}{c}\text { Stratigraphy and } \\
\text { depositional } \\
\text { environment }\end{array}$ & $\begin{array}{c}1716 \\
\text { borrow pit } \\
\text { sample ID }\end{array}$ & $\begin{array}{c}\text { Sample } \\
\text { deptha } \\
\text { (centimeter) }\end{array}$ & $\mathbf{A g}$ & Sn & Sb & Cs & $\mathrm{Ba}$ & $B \mathbf{i}$ & La & $\mathrm{Ce}$ & Pr & $\mathbf{N d}$ & $\mathrm{Sm}$ & Eu \\
\hline \multirow{11}{*}{$\begin{array}{l}\text { Very well-sorted, } \\
\text { fine and very } \\
\text { fine, near- } \\
\text { shore marine/ } \\
\text { estuarine quartz } \\
\text { sand }\end{array}$} & 15 & 20.0 & 1 & $<1$ & 1 & $<0.5$ & 259 & $<0.4$ & 16.8 & 32.7 & 3.79 & 15 & 3 & 0.52 \\
\hline & 14 & 40.0 & 0.6 & $<1$ & 0.9 & $<0.5$ & 292 & $<0.4$ & 6.6 & 12.4 & 1.43 & 5.1 & 1.1 & 0.22 \\
\hline & 13 & 60.0 & 0.9 & $<1$ & 0.9 & $<0.5$ & 258 & $<0.4$ & 7.8 & 15.1 & 1.78 & 7.2 & 1.4 & 0.27 \\
\hline & 12 & 80.0 & 0.8 & $<1$ & 0.9 & 0.5 & 227 & $<0.4$ & 8.4 & 15.5 & 1.85 & 6.7 & 1.4 & 0.29 \\
\hline & 10 & 120.0 & 0.7 & $<1$ & 1.1 & $<0.5$ & 227 & $<0.4$ & 8 & 14.4 & 1.64 & 6.2 & 1.3 & 0.26 \\
\hline & 9 & 140.0 & 1.1 & 1 & 0.9 & 0.9 & 202 & $<0.4$ & 14.3 & 26.8 & 3.06 & 11.2 & 2.2 & 0.32 \\
\hline & 8 & 160.0 & 1.7 & 2 & 1.4 & 1.3 & 170 & 0.4 & 18.9 & 33.8 & 3.85 & 13.9 & 2.7 & 0.37 \\
\hline & 7 & 180.0 & 2.3 & 1 & 1.1 & 0.8 & 143 & $<0.4$ & 18 & 34.5 & 4.01 & 14.4 & 2.9 & 0.32 \\
\hline & 3 & 260.0 & 1.7 & $<1$ & 0.9 & 0.6 & 136 & $<0.4$ & 14.4 & 27.7 & 3.18 & 11.5 & 2.2 & 0.24 \\
\hline & 2 & 280.0 & 1.9 & 1 & 1.1 & 0.6 & 135 & $<0.4$ & 14.6 & 28.6 & 3.18 & 12.2 & 2.3 & 0.23 \\
\hline & 1 & $>300$ & 1.7 & $<1$ & 1.2 & 0.7 & 137 & $<0.4$ & 15.7 & 31.4 & 3.52 & 13 & 2.5 & 0.26 \\
\hline
\end{tabular}

aSample depth is measured from the ground surface. 


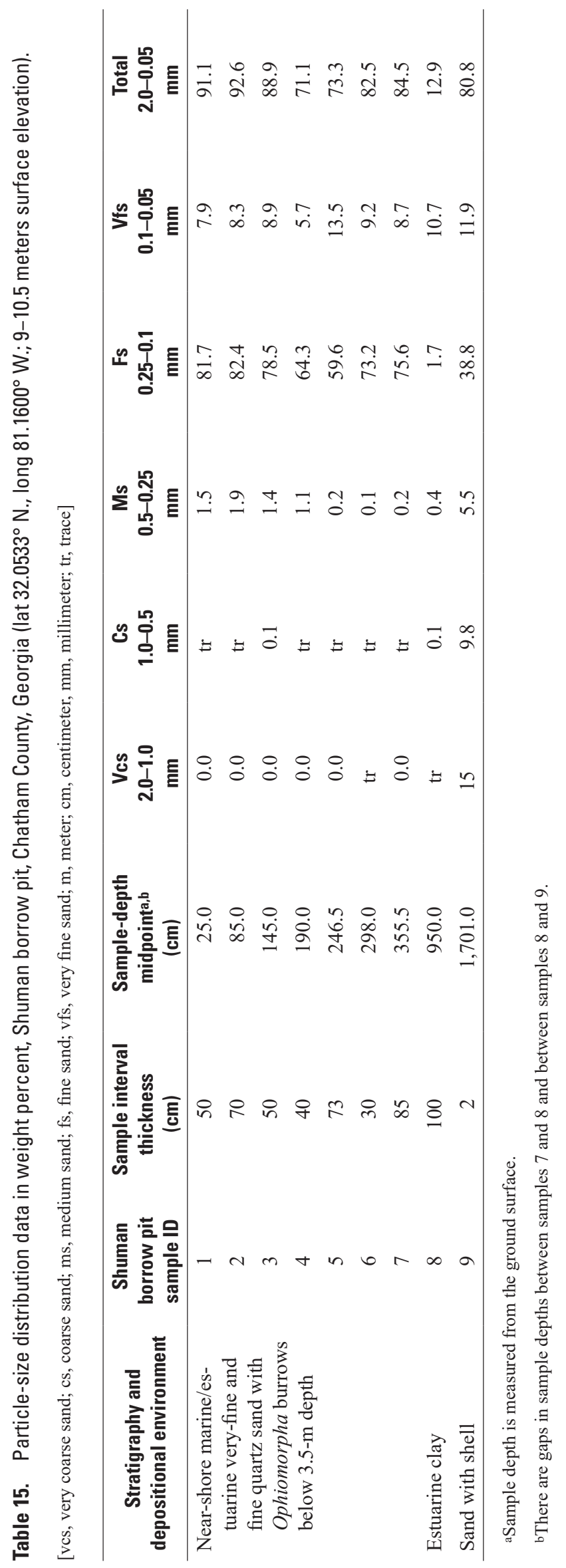




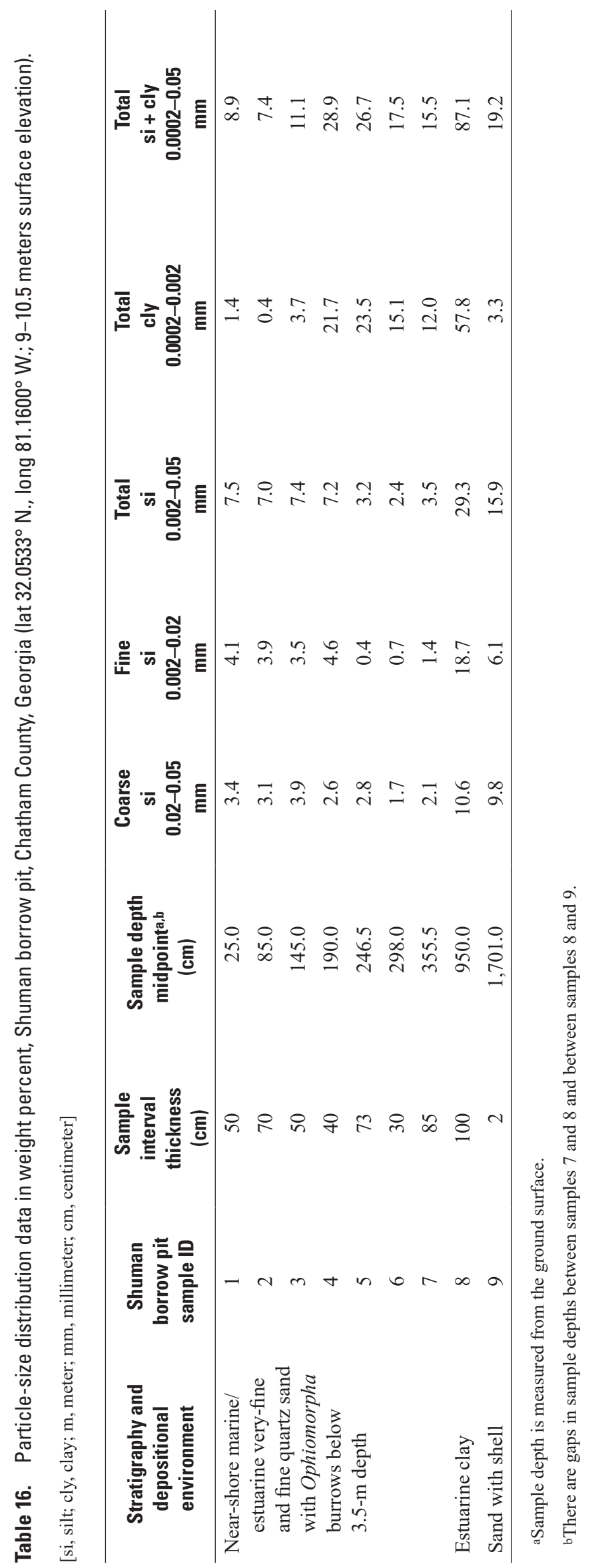


Table 17. Major element oxide chemistry in weight percent for samples from the Shuman borrow pit, Chatham County, Georgia (lat $32.0533^{\circ} \mathrm{N}$. , long $81.1600^{\circ} \mathrm{W} . ;$

[(T) indicates total iron reported as an oxide; $\mathrm{cm}$, centimeter; $\mathrm{m}$, meter]

\begin{tabular}{lcccccc}
\hline $\begin{array}{c}\text { Stratigraphy and } \\
\text { depositional environment }\end{array}$ & $\begin{array}{c}\text { Shuman } \\
\text { borrow pit } \\
\text { sample ID }\end{array}$ & $\begin{array}{c}\text { Sample interval } \\
\text { thickness } \\
\text { (cm) }\end{array}$ & $\begin{array}{c}\text { Sample } \\
\text { deptha } \\
\text { (cm) }\end{array}$ & $\mathbf{S i O}_{\mathbf{2}} \mathbf{b}, \mathbf{c}$ & $\mathbf{A l}_{\mathbf{2}} \mathbf{O}_{\mathbf{3}}$ & $\begin{array}{c}\mathbf{F e}_{\mathbf{2}} \mathbf{O}_{\mathbf{3}} \\
\text { (T) }\end{array}$ \\
\hline $\begin{array}{l}\text { Near-shore marine/estuarine very- } \\
\text { fine and fine, quartz sand with }\end{array}$ & 1 & 50 & 25.0 & 95 & 1.64 & 0.55 \\
Ophiomorpha burrows in the & 2 & 70 & 85.0 & 96 & 1.38 & 0.49 \\
below 3.5-m depth & 3 & 50 & 145.0 & 95 & 1.87 & 0.66 \\
& 4 & 40 & 190.0 & 84 & 7.51 & 1.96 \\
& 5 & 73 & 246.5 & 84 & 7.95 & 2.25 \\
& 6 & 30 & 298.0 & 88 & 6.2 & 1.21 \\
\hline
\end{tabular}

aSample depth measured is measured from the surface.

bTotal iron reported as an oxide.

'Detection limit is 0.01 .

\section{Summary of Age Data}

This report presents age data for emergent shoreline deposits in the LSRA in Georgia. The assigned ages are based on stratigraphic position, lithostratigraphy, fossil content, soil and weathering diagnostic properties, and numerical ages based on ${ }^{10} \mathrm{BePRT}$, U-series, AAR, ${ }^{14} \mathrm{C}$, and OSL analyses. The following paragraphs present a preliminary geochronology for these deposits based on these data.

- The 1 Ma minimum ${ }^{10}$ BePRT age for the paleosol developed in nearshore marine sand and clay atop the Orangeburg Scarp indicates scarp formation sometime prior to $1 \mathrm{Ma}$. The ${ }^{87} \mathrm{Sr} / 86 \mathrm{Sr}$ based ages of 3.6 to 2.0 Ma for Duplin deposits, and 2.1 to 1.5 Ma for Waccamaw deposits, seaward of the Orangeburg Scarp in southeastern North Carolina indicate deposition in the middle to late Pliocene to early Pleistocene. These numerical ages agree with the late Pliocene to early Pleistocene fossil-based age assignment for Duplin/ Raysor deposits in the LSRA. The combined age data indicate a minimum period of $10^{6}$ years for formation of the Orangeburg Scarp and a no-younger-than middle Pliocene age for deposits atop and landward of the Scarp.

- The minimum $360 \mathrm{ka}$ and maximum $420 \mathrm{ka}$ ages for deposits of the Wicomico Shoreline Complex were calculated from ${ }^{10}$ BePRT and OSL analyses for deposits of the Wicomico barrier and the overlying eolian sand, and from OSL ages for marine and eolian deposits landward and seaward of the Wicomico barrier. The combined ages indicate Wicomico Shoreline Complex deposition occurred in the middle Pleistocene.
- A minimum age of $225 \mathrm{ka}$ and an age range of 360 to $260 \mathrm{ka}$ for barrier/beach-ridge deposits of the Penholoway Shoreline Complex are calculated from ${ }^{10}$ BePRT and OSL ages of the marine deposits and the overlying eolian sand. These ages and the position of the Penholoway Shoreline Complex seaward of the Wicomico Shoreline Complex indicate deposition after that of the Wicomico Shoreline Complex, but still in the middle Pleistocene.

- No numerical ages are available for deposits mapped as part of the Talbot Shoreline Complex, but its position seaward of the Penholoway Shoreline Complex and landward of the Pamlico Shoreline Complex indicates an age younger than approximately $260 \mathrm{ka}$.

- A minimum age of $200 \mathrm{ka}$ and an age range of 300 to $200 \mathrm{ka}$ for barrier deposits of the Pamlico Shoreline Complex were calculated from previously unpublished ${ }^{10} \mathrm{BePRT}$ and OSL ages for these deposits and OSL and ${ }^{14} \mathrm{C}$ ages for marine and terrestrial deposits seaward of this complex. The age range overlaps with that of the Talbot Shoreline Complex and indicates deposition immediately succeeding deposition of the Talbot Shoreline Complex and overlap/removal of most Talbot age deposits by the Pamlico sea level highstand.

- AAR, ${ }^{14} \mathrm{C}$, and OSL ages indicate multiple periods of deposition in the middle Pleistocene through the early Holocene for the Princess Anne Shoreline Complex.

- U-series, OSL and ${ }^{14} \mathrm{C}$ ages indicate Silver Bluff Shoreline Complex deposition in the late Pleistocene.

- OSL and ${ }^{14} \mathrm{C}$ ages indicate Holocene Shoreline Complex deposition in the late Pleistocene and Holocene. 


\section{General Observations Based on the Age Data}

The following are general observations for the Orangeburg Scarp and for emergent paleoshoreline deposits and geomorphically identifiable shoreline complexes in LSRA. These observations are based on the age data presented in this report.

- LSRA shoreline complexes represent deep sea marine oxygen isotope stages (MIS) 11e (Wicomico); 9e, 9c, and 9a (Penholoway); 7e, 7c, and 7a (Talbot and Pamlico); possibly 11, 9, 7 and 5e? (Princess Anne); and 5c and 5a (Silver Bluff). Ages less than $70 \mathrm{ka}$ for Princess Anne, Silver Bluff, and Holocene Shoreline Complex deposits below $8 \mathrm{~m}$ elevation indicate intermittent nearshore marine deposition in MIS4, MIS3, MIS2, and MIS1 (MIS assignments based on LR04 stack as presented in Railsback and others, 2015, fig. 3).

- Paleosol data for barrier islands facies of LSRA shoreline complex deposits generally agree with their relative positions in the landscape. The paleosol developed in Wicomico (Qwi) barrier/beach-ridge deposits has a 2-m-thick B horizon. Paleosols in the Penholoway (Qpni) (Chimney Road core, fig. 2C) and the Pamlico (Qpmi) barrier deposits (1716 and Shuman pits, fig. $2 B$ ) each have a 1-m-thick B horizon. The maximum paleosol B horizon combined clay and silt $(<0.063 \mathrm{~mm})$ content is 34 weight percent in the Wicomico, 24 in the Penholoway, and 29 in the Pamlico. Minimum paleosol B horizon clay mass is $72 \mathrm{~g} / \mathrm{cm}^{2}$ for the Wicomico, 54 for the Penholoway, and 25 for the Pamlico. Paleosol B horizon $\mathrm{Fe}_{2} \mathrm{O}_{3}+\mathrm{Al}_{2} \mathrm{O}_{3} / \mathrm{SiO}_{2}$ values are 15-20 for the Wicomico, 9-14 for the Penholoway, and 5-12 for the Pamlico. Paleosol B horizon colors are high value, high chroma 10R 6/6 and 10YR 8/6 in the Wicomico, medium value and chroma 5YR 4/4 in the Penholoway, and medium to high value, high chroma 5 YR $5 / 6$ to $5 / 8$ and 7.5YR 5/6 to 5/8 in the Pamlico. Using the criteria in Markewich and others (1989), the ages of these paleosols plot between 500 and $200 \mathrm{ka}$.

- LSRA Pleistocene shoreline deposits indicate a record of sea level highstands that are not in complete agreement with modeled global sea levels.

- Early Pleistocene deposits are identified only at a few localities near the surface and in core, and the identifications are based on limited microfossil assemblages. Available data indicate a period of more than 1 million years between deposition of the late Pliocene and early Pleistocene sands and gravels (map unit PPs, Lawton and others [1976]) and the middle Pleistocene Wicomico Shoreline Complex (map units facies Qwi and Qwm, Lawton and others [1976]).

- No last interglacial (130 to $115 \mathrm{ka}$ ) marine deposits (MIS5e) have been positively identified.

- The occurrence of 117 to 80 ka marine deposits (MIS5c and MIS5a) and 70 to 10 ka marine deposits (MIS4, MIS3, and MIS2) near present sea level conflicts with modeled global sea levels for these time periods. Modeled sea levels for these time periods are tens of meters lower than present sea level, indicating intermittent periods of cooler temperatures and greater ice volumes. Regionally extensive eolian sand deposits and braided stream deposits with ages in these time intervals also indicate cold, dry, winddominated environments.

\section{Concluding Comment}

As a synthesis of available age and stratigraphic data for emergent shoreline deposits seaward of the Orangeburg Scarp in the lower Savannah River area (LSRA) of Georgia, this report is purposely not interpretive. Observations based on the data presented in the report lead to specific questions that cannot be answered without considerably more local and regional data. Researchers have begun to identify and study some of the variables in Pliocene and Pleistocene global sea levels and regional/local variations in those levels. For example,

- Current research focusing on established lithostratigraphy, established deposit chronologies, microfossil distance from shore indicators, and crustal deformation resulting from glacioisostasy now allows tentative correlation of Atlantic Coastal Plain (ACP) MIS 5, MIS 7, and MIS 9 sea level highstands from Florida to Maryland (Poirier and others, 2014, 2015, 2016).

- In the southeastern Atlantic Coastal Plain (SEACP), near-present-sea level nearshore marine deposits contain flora and fauna that indicate warm-temperate climates and sea level highstands. Eolian dunes and sand sheets, and braided river fluvial deposits in this region indicate relatively cool to cold and dry climatic conditions with sufficiently strong winds to geomorphically alter the landscape. The apparently coincident presence of these deposits is enigmatic. Jiménez-Moreno and others (2010) and Litwin and others (2013) have shown that the conflicting late Pleistocene paleoclimate data may be related to millennial and submillenial scale variations in vegetation 
resulting from Dansgaard-Oeschger and Heinrich ${ }^{7}$ climate variability in the North Atlantic Ocean. This area of research may provide resolution of near present sea level MIS4, MIS3, and early MIS2 marine deposits occurring coeval with eolian sand dunes and braided stream deposits in many of the SEACP river valleys (for example, Hoyt, 1968; Owens and Denny, 1979; Pirkle and others, 1991; Rich and Pirkle, 1993; Pavich and others, 2006; Jiménez-Moreno and others, 2010; Swezey and others, 2013, 2018, 2019; Markewich and others, 2015, and included references).

The rapid and large-scale changes in global sea levels, resulting from long and short term changes in climate, as well as the effects of epeirogenic uplift and isostatically induced crustal uplift and subsidence, continue to be studied and debated. The ability to constrain the timing of these events facilitates understanding of the spatial and temporal dynamics of sea level change, including present global sea level rise. Age data presented in this report for emergent Pliocene and Pleistocene deposits in the LSRA add to our understanding of these events in the SEACP.

\section{References Cited}

Alemán-González, W.B., Schultz, A.P., Markewich, H.W., and Edwards, L.E., 2018, Sediments of the South Effingham Middle School core, Effingham County, Georgia: USGS outreach poster of the stratigraphy of the South Effingham Middle School core for use by school teaching staff.

American Geological Institute, 1962, The dictionary of geological terms: Garden City, New York, Doubleday \& Company, Dolphin Books, 545 p.

Bacon, A.R., Richter, D., Bierman, P.R., and Rood, D.H., 2012, Coupling meteoric ${ }^{10} \mathrm{Be}$ with pedogenic losses of ${ }^{9} \mathrm{Be}$ to improve soil residence time estimates on an ancient North American interfluve: Geology, v. 40, no. 9, p. 847-850, accessed November 12, 2020, at https://pubs. geoscienceworld.org/gsa/geology/article/40/9/847/131041/ coupling-meteoric-10be-with-pedogenic-losses-of.

Bates, R.L., and Jackson, J.A., eds., 1987, Glossary of geology (3d ed.): Alexandria, Va., American Geological Institute, $788 \mathrm{p}$.

\footnotetext{
${ }^{7}$ Dansgaard-Oeschger events are considered to be periods of globally synchronous abrupt warming and subsequent slow cooling. Heinrich events are a series of iceberg discharges into the North Atlantic Ocean. Together these events record swift and large changes in global temperatures during the middle and late Pleistocene.
}

Bishop, G.A., Rollins, H.B., and Thomas, D.H., 2011, Geoarchaeology of St. Catherines Island, Georgia: Anthropological Papers of the American History Museum of Natural History, no. 94, 391 p., accessed November 12, 2020, at http://digitallibrary.amnh.org/handle/2246/6105.

Blackwelder, B.W., 1981, Late Cenozoic marine deposition in the United States Atlantic Coastal Plain related to tectonism and global climate: Palaeogeography, Palaeoclimatology, Palaeoecology, v. 34, p. 87-114, accessed November 12, 2020, at https://doi.org/10.1016/0031-0182(81)90059-6.

Blackwelder, B.W., and Ward, L.W., 1979, Stratigraphic revision of the Pliocene deposits of North and South CarolinaSouth Carolina Geological Survey: Geologic Notes, v. 23, p. 33-43. [Also available at https://www.dnr.sc.gov/geology/journals.html.]

Booth, R.K., and Rich, F.J., 1999, Identification and paleoecological implications of a late Pleistocene Pteridophytedominated assemblage preserved in brown peat from St. Catherines Island, Georgia: Castanea, v. 64, no. 2, p. 120-129, accessed November 12, 2020, at https://www. jstor.org/stable/4033932? seq=1\#metadata_info_tab_ contents.

Booth, R.K., Rich, F.J., and Bishop, G.A., 1999, Palynology and depositional history of late Pleistocene and Holocene coastal sediments from St. Catherines Island, Georgia, U.S.A: Palynology, v. 23, no. 1, p. 67-86, accessed November 11, 2020, at https://pubs.geoscienceworld.org/ palynology/article-abstract/23/1/67/86990/palynology-anddepositional-history-of-late.

Booth, R.K., Rich, F.J., and Jackson, S.T., 2003, Paleoecology of mid-Wisconsinan peat clasts from Skidaway Island, Georgia: PALAIOS, v. 18, p. 63-68, accessed November 12, 2020, at https://pubs.geoscienceworld.org/ sepm/palaios/article/18/1/63/114373/Paleoecology-of-MidWisconsinan-Peat-Clasts-from.

Brown, L., Pavich, M.J., Hickman, R.E., Klein, J., and Middleton, R., 1988, Erosion of the eastern United States observed with ${ }^{10} \mathrm{Be}$ : Earth Surface Processes and Landforms, v. 13, no. 5, p. 441-457, accessed January 23, 2020, at https://doi.org/10.1002/esp.3290130509.

Campbell, L., Campbell, S., Colquhoun, D., and Ernissee, J., 1975, PlioPieistocene faunas of the central Carolina Coastal Plain-South Carolina Geological Survey: Geologic Notes, v. 19, p. 51-124. [Also available at https://www.dnr.sc.gov/geology/journals.html.]

Chatham County Georgia, 2011, Savannah area geographic information system, 1.0-point $/ \mathrm{m}^{2} \mathrm{LiDAR}$ terrain dataset: Chatham County, Georgia, ESRI ArcGIS geodatabase. 
Coastal Georgia Elevation Project, 2011, Raster 4-ft digitalelevation model generated from 1.0 point $\mathrm{m}^{-2} \mathrm{LiDAR}$ for Brantley, Bryan, Bulloch, Camden, Charlton, Effingham, Long, McIntosh, Screven, and Wayne Counties, Georgia: Photo Science Inc. and Fugro EarthData Inc., CGEP NOAA Contract EA133C05CQ1052.

Colquhoun, D.J., 1965, Terrace sediment complexes in central South Carolina-Atlantic Coastal Plain Geological Association Field Conference 1965: Columbia, South Carolina, University of South Carolina, Department of Geology, 62 p.

Colquhoun, D.J., 1988, The geology and physiography of the Orangeburg Scarp, in Neathery, T.L., ed., Southeastern Section of the Geological Society of America, Geological Society of America - Centennial field guide 6: Boulder, Colo., Geological Society of America p. 321-322, accessed November 11, 2020, at https://doi.org/10.1130/0-81375406-2.321.

Colquhoun, D.J., Johnson, G.H., Peebles, P.C., Huddleston, P.F., and Scott, T., 1991, Quaternary geology of the Atlantic coastal plain, in Morrison, R.B., ed., Quaternary nonglacial geology - Conterminous U.S: Boulder, Colorado, Geological Society of America, Geology of North America, K-2, p. 629-650, accessed November 11, 2020, at https://doi.org/10.1130/DNAG-GNA-K2.629.

Cooke, C.W., 1925, Physical geography of Georgia: Geological Survey of Georgia Bulletin, v. 42, p. 21-35, accessed November 11, 2020, at https://epd.georgia.gov/ outreach/publications/georgia-geologic-survey-bulletins.

Cooke, C.W., 1930a, Correlation of coastal terraces: The Journal of Geology, v. 38, no. 7, p. 577-589, accessed November 12, 2020, at https://doi.org/10.1086/623762.

Cooke, C.W., 1930b, Pleistocene seashores: Washington Academy of Sciences Journal, v. 20, no. 16, p. 389-395, accessed November 11, 2020, at https://www.jstor.org/ stable/24523707.

Cooke, C.W., 1931, Seven coastal terraces in the southeastern States: Washington Academy of Sciences Journal, v. 21, no. 21 , p. 503-513, accessed November 11, 2020, at ht tps://www.jstor.org/stable/24525810.

Cooke, C.W., 1943, Geology of the Coastal Plain of Georgia: U.S. Geological Survey Bulletin 941, 121 p., 1 plate, accessed November 10, 2020, at http://pubs.er.usgs.gov/ publication/b941.

Counts, H.B., and Donsky, E., 1963, Salt-water encroachment geology and ground-water resources of Savannah area Georgia and South Carolina: U.S. Geological Survey Water Supply Paper 1611, 100 p., accessed November, 11, 2020, at https://pubs.er.usgs.gov/publication/wsp1611.
Cronin, T.M., Bybell, L.M., Poore, R.Z., Blackwelder, B.W., Liddicoat, J.C., and Hazel, J.E., 1984, Age and correlation of emerged Pliocene and Pleistocene deposits, U.S. Atlantic Coastal Plain: Palaeogeography, Palaeoclimatology, Palaeoecology, v. 47, no. 1-2, p. 21-51, accessed November 12, 2020, at https://doi.org/10.1016/00310182(84)90079-8.

Cronin, T.M., Szabo, B.J., Ager, T.A., Hazel, J.E., and Owens, J.P., 1981, Quaternary climates and sea levels of the U.S. Atlantic Coastal Plain: Science, v. 211, no. 4479, p. 233-240, accessed November 12, 2020, at https://doi.org/ 10.1126/science.211.4479.233.

Darby, D.G., and Hoyt, J.H., 1964, An upper Miocene fauna dredged from tidal channels of coastal Georgia: Journal of Paleontology, v. 38, no. 1, p. 67-73, accessed November 12, 2020, at https://www.jstor.org/stable/1301491.

Doar, W.R., III, and Kendall, C.G.S.C., 2014, An analysis and comparison of observed Pleistocene South Carolina (USA) shoreline elevations with predicted elevations derived from Marine Oxygen Isotope Stages: Quaternary Research, v. 82, no. 1, p. 164-174, accessed November 12, 2020, at https://doi.org/10.1016/j.yqres.2014.04.005.

Doering, J.A., 1960, Quaternary surface formation of southern part of Atlantic Coastal Plain: The Journal of Geology, v. 68 , no. 2, p. 182-202, accessed November 12, 2020, at https://doi.org/10.1086/626652.

Dowsett, H.J., and Cronin, T.M., 1990, High eustatic sea level during the middle Pliocene-Evidence from the southeastern U.S. Atlantic Coastal Plain: Geology, v. 18, no. 5, p. 435-438, accessed November 12, 2020, at https://doi. org/10.1130/0091-7613(1990)018\%3C0435:HESLDT\%3E 2.3.CO;2.

DuBar, J.R., 1971, Neogene stratigraphy of the lower Coastal Plain of the Carolinas: Atlantic Coastal Plain Geological Association, 12th Annual Field Conference, Myrtle Beach, S.C., 1971 Guidebook, 128 p.

DuBar, J.R., Johnson, H.S., Jr., Thom, B., and Hatchell, W.O., 1974, Neogene stratigraphy and morphology, south flank of the Cape Fear Arch, North and South Carolina, in Oaks, R.Q., Jr., and Du Bar, J.R., eds., Post-Miocene stratigraphy, central and southern Atlantic Coastal Plain: Logan, Utah, Utah State University Press, p. 139-173.

Frye, J.C., and Willman, H.B., 1960, Classification of the Wisconsinan stage in the Lake Michigan glacial lobe: Illinois State Geological Survey, Circular 285, p. 7-8, accessed November 17, 2020, at https://www.ideals.ill inois.edu/bitstream/handle/2142/35121/classificationof28 5 frye.pdf? sequence $=2 \&$ is Allowed $=\mathrm{y}$. 
Furlow, J.W., 1969, Stratigraphy and economic geology of the eastern Chatham County phosphate deposit: Georgia Geological Survey Bulletin 82, p. 16-20, accessed November 12, 2020, at https://epd.georgia.gov/document/ publication/b-82-stratigraph-and-economic-geologyeastern-chatham-county-phosphate/download.

Gallaher, R.N., Perkins, H.F., Tan, D.H., and Radcliffe, D., 1973, Soil concretions-II, Mineralogical analysis: Soil Science Society of America Journal, v. 37, no. 3, p. 469-472, accessed November 12, 2020, at https://doi.org/ 10.2136/sssaj1973.03615995003700030042x.

Gary, M., McAfee, R., Jr., and Wolf, C.L., eds., 1972, Glossary of geology: Washington, D.C., American Geological Institute, 805 p.

Graly, J., Bierman, P.R., Reusser, L., and Pavich, M., 2010, Meteoric ${ }^{10} \mathrm{Be}$ in soil profiles a global metaanalysis: Geochimica et Cosmochimica Acta, v. 74, no. 23, p. 6814-6829, accessed November 12, 2020, at https://doi.org/10.1016/j.gca.2010.08.036.

Graly, J., Reusser, L., and Bierman, P.R., 2011, Short and long-term delivery rates of meteoric ${ }^{10} \mathrm{Be}$ to terrestrial soils: Earth and Planetary Science Letters, v. 302, no. 3-4, p. 329-336, accessed November 12, 2020, at https://doi.org/ 10.1016/j.epsl.2010.12.020.

Gray, H.J., Mahan, S.A., Rittenour, T., and Nelson, M., 2015, Guide to luminescence dating techniques and their applications for paleoseismic research, in Lund, W.R., ed., Proceedings volume, Basin and Range Province seismic hazards summit III: Utah Geological Survey Miscellaneous Publication 15-5, 19 p., accessed November 12, 2020, at https:/ugspub.nr.utah.gov/publications/misc_pubs/mp-15-5/ mp-15-5_invited_paper.pdf.

Graybill, E.A., Harris, W.B., Kelley, P., Dietl, G., and Visaggi, C.C., 2009, Age of the Duplin and Waccamaw Formations, Cape Fear River basin, North Carolina [abs]: Geological Society of America Abstracts with Programs, v. 41, no. 1, p. 45, accessed November 12, 2020, at https://gsa.c onfex.com/gsa/2009SE/webprogram/Paper154208.html.

Hails, J.R., and Hoyt, J.H., 1969, An appraisal of the evolution of the lower Atlantic Coastal Plain of Georgia, U.S.A: Transactions of the Institute of British Geographers, v. 46, no. 46, p. 53-68, accessed November 12, 2020, at https://doi.org/10.2307/621408.

Harris, M.S., Gayes, P.T., Kindinger, J.L., Flocks, J.G., Krantz, D.E., and Donovan, P., 2005, Geomorphology and modern coastal development in response to an inherent geologic framework-An example from Charleston, South Carolina: Journal of Coastal Research, v. 21, no. 1, p. 42-43 and p. 49-64, accessed November 12, 2020, at https://www. jstor.org/stable/4299390.
Herrick, S.M., 1965, A subsurface study of Pleistocene deposits in coastal Georgia: Georgia State Division of Conservation, Department of Mines and Geology, The Geological Survey, Information Circular 31, 8 p., accessed November 12, 2020, at https://epd.georgia.gov/document/ publication/ic-31-subsurface-study-pleistocene-depositscoastal-georgia-1965/download

Hoyt, J.H., 1968, Geology of the Golden Isles and lower Georgia Coastal Plain, in Maney, D.S., ed., The future of the marshlands and sea islands of Georgia: Georgia Natural Areas Council and Coastal Area Planning and Development Commission p. 18-34.

Hoyt, J.H., and Hails, J.R., 1967, Pleistocene shoreline sediments in coastal Georgia-Deposition and modification: Science, v. 155, no. 3769, p. 1541-1543, accessed November 12, 2020, at https://doi.org/10.1126/science.155 .3769 .1541 .

Hoyt, J.H., and Hails, J.R., 1974, Pleistocene stratigraphy of southeastern Georgia, in Oaks, R.Q., Jr., and DuBar, J.R., eds., Post-Miocene stratigraphy, central and southern Atlantic Coastal Plain: Logan, Utah, Utah State University Press, p. 191-205.

Hoyt, J.H., Henry, V.J., Jr., and Weimer, R.J., 1968, Age of late-Pleistocene shoreline deposits, coastal Georgia, in Morrison, R.B., and Wright, H.E., eds., Means of correlation of Quaternary successions: Proceedings VII Congress International Association for Quaternary Research, v. 8, p. 381-393.

Huddlestun, P.F., 1988, The Miocene through Holocene-A revision of the lithostratigraphic units of the Coastal Plain of Georgia: Department of Natural Resources, Environmental Protection Division, Georgia Geologic Survey Bulletin 104, 162 p., accessed November 12, 2020, at https://epd.ge orgia.gov/sites/epd.georgia.gov/files/related_files/site_page/ B-104.pdf.

Hulbert, R.C., III, and Pratt, A.E., 1998, New Pleistocene (Rancholabrean) vertebrate faunas from coastal Georgia: Journal of Vertebrate Paleontology, v. 18, no. 2, p. 412-429, accessed December 10, 2020, at https://doi.org/10.1080/02 724634.1998.10011069.

Jiménez-Moreno, G., Anderson, R.S., Desprat, S., Grigg, L.D., Grimm, E.C., Heusser, L.E., Jacobs, B.F., López-Martinez, C., Whitlock, C.L., and Willard, D.A., 2010, Millennialscale variability during the last glacial in vegetation records from North America: Quaternary Science Reviews, v. 29, no. 21-22, p. 2865-2881, accessed November 12, 2020, at https://doi.org/10.1016/j.quascirev.2009.12.013. 
Korschinek, G., Bergmaier, A., Faestermann, T., Gerstmann, U.C., Knie, K., Rugel, G., Wallner, A., Dillmann, I., Dollinger, G., vonGostomski, C.L., Kossert, K., Maiti, M., Poutivtsev, M., and Remmert, A., 2010, A new value for the half-life of ${ }^{10} \mathrm{Be}$ by heavy ion elastic recoil detection and liquid scintillation counting: Nuclear Instruments and Methods in Physics Research, Section B, v. 268, no. 2, p. 187-191, accessed November 12, 2020, at https://doi.org/ 10.1016/j.nimb.2009.09.020.

Lamothe, M., 2016, Luminescence dating of interglacial coastal depositional systems - Recent developments and future avenues of research: Quaternary Science Reviews, v. 146, p. 1-27, accessed November 12, 2020, at https://doi.org/10.1016/j.quascirev.2016.05.005.

Lawton, D.E., Moye, F.J., Murray, J.B., O’Connor, B.J., Penley, H.M., Sandrock, G.S., Marsalis, W.E., Friddell, M.S., Hetrick, J.H., Huddlestun, P.F., Hunter, R.E., Mann, W.R., Martin, B.F., Pickering, S.M., Schneeberger, F.J., and Wilson, J.D., 1976, Geologic map of Georgia: Georgia Geological Survey, 1 sheet, 1:500,000 scale, accessed November 12, 2020, at https://epd.georgia.gov/document/ publication/sm-3-geologic-map-georgia-1500000-1976/ download.

Liddicoat, J.C., McCartan, L., Weems, R.E., and Lemon, E.M., Jr., 1981, Paleomagnetic investigation of Pliocene and Pleistocene sediments in the Charleston, South Carolina, area [abs]: Geological Society of America Abstracts with Programs, v. 13, no. 1, p. 28-29.

Liddicoat, J.C., and Opdyke, N.D., 1981, Magnetostratigraphy of sediments in the Atlantic Coastal Plain and Pacific Coast of the United States as an aid for dating tectonic deformation: U.S. Geological Survey Open-File Report 81-232, 25 p., accessed November 12, 2020, at https://pubs.er .usgs.gov/publication/ofr81232.

Litwin, R.J., Smoot, J.P., Pavich, M.J., Markewich, H.W., Brook, G.A., and Durika, N.J., 2013, 100,000-year-long terrestrial record of millennial-scale linkage between eastern North American midlatitude paleovegetation shifts and Greenland ice-core oxygen isotope trends: Quaternary Research, v. 80, no. 2, p. 291-315, accessed November 12, 2020, at https://doi.org/10.1016/j.yqres.2013.05.003.

Ludwig, K.R., Muhs, D.R., Simmons, K.R., Halley, R.B., and Shinn, E.A., 1996, Sea-level records at $\sim 80$ ka from tectonically stable platforms - Florida and Bermuda: Geology, v. 24, no. 3, p. 211-214, accessed November 12, 2020, at https://doi.org/10.1130/0091-7613(1996)024\%3C0211:SLR AKF\%3E2.3.CO;2.
Markewich, H.W., Hacke, C.M., and Huddlestun, P.F., 1992, Emergent Pliocene and Pleistocene sediments of southeastern Georgia-An anomalous, fossil-poor, clastic section, in Fletcher, C.H., III, and Wehmiller, J.F., eds., Quaternary coasts of the United States-Marine and lacustrine systems: SEPM Special Publication 48, p. 173-189, accessed November 12, 2020, at https://doi.org/10.2110/ pec.92.48.0173.

Markewich, H.W., Litwin, R.J., Wysocki, D.A., and Pavich, M.J., 2015, Synthesis on Quaternary aeolian research in the unglaciated eastern United States: Aeolian Research, v. 17, p. 139-191, accessed November 12, 2020, at https://doi.org/ 10.1016/j.aeolia.2015.01.011.

Markewich, H.W., and Pavich, M.J., 1991, Soil chronosequence studies in temperate to subtropical, low-latitude, low-relief terrain with data from the eastern United States, in Pavich, M.J., ed., Weathering and soils: Geoderma, v. 51, p. 213-239, accessed November 12, 2020, at https://doi.org/ 10.1016/0016-7061(91)90072-2.

Markewich, H.W., and Pavich, M.J., 1996, Preliminary results for soil chronosequence and ${ }^{10} \mathrm{Be}$ analyses of emergent Pleistocene barrier deposits, southeastern Georgia, USA [abs]: Geological Society of America Abstracts with Programs, v. 28, no. 2, p. 20.

Markewich, H.W., Pavich, M.J., Mausbach, M.J., Johnson, R.G., and Gonzalez, V.M., 1989, A guide for using soil and weathering profile data in chronosequence studies of the Coastal Plain of the Eastern United States: U.S. Geological Survey Bulletin 1589-D, 39 p., accessed November 12, 2020, at https://pubs.er.usgs.gov/publication/b1589D.

Markewich, H.W., Pavich, M.J., Mausbach, M.J., Stuckey, B.N., Johnson, R.G., and Gonzalez, V.M., 1986, Soil development and its relation to the ages of morphostratigraphic units in Horry County South Carolina: U.S. Geological Survey Bulletin 1589-B, 61 p., accessed November 12, 2020, at https://pubs.usgs.gov/bul/1589b/report.pdf.

Markewich, H.W., Pavich, M.J., Schultz, A.P., Mahan, S.A., Alemán-González, W.B., and Bierman, P.R., 2013, Geochronologic evidence for a possible MIS-11 emergent barrier/beach-ridge in southeastern Georgia, USA: Quaternary Science Reviews, v. 60, p. 49-75, accessed November 12, 2020, at https://doi.org/10.1016/j.quascirev.2 012.10.041.

McCartan, L., Lemon, E.M., and Weems, R.E., 1984, Geologic map of the area between Charleston and Orangeburg, South Carolina: U.S. Geological Survey Miscellaneous Investigations Series Map, I-1472, 1:250,000 scale, accessed November 12, 2020, at https://pubs.er.usgs.gov/ publication/i1472. 
McCartan, L., Owens, J.P., Blackwelder, B.W., Szabo, B.J., Belknap, D.F., Kriausakul, N., Mitterer, R.M., and Wehmiller, J.F., 1982, Comparison of amino acid racemization geochronometry with lithostratigraphy, biostratigraphy, uranium-series coral dating, and magnetostratigraphy in the Atlantic Coastal Palin of the southeastern United States: Quaternary Research, v. 18, no. 3, p. 337-359, accessed November 12, 2020, at https://doi.org/10.1016/00335894(82)90078-3.

McCartan, L., Weems, R.E., and Lemon, E.M., Jr., 1990, Quaternary stratigraphy in the vicinity of Charleston, South Carolina, and its relationship to local seismicity and regional tectonism, in Studies related to the Charleston, South Carolina, earthquake of 1886-Neogene and Quaternary lithostratigraphy and biostratigraphy: U.S. Geological Survey Professional Paper 1367, p. A1-A39, accessed November 12, 2020, at https://pubs.usgs.gov/pp/ 1367/report.pdf.

McGregor, D.A., Harris, W.B., Dietl, G.P., and Kelly, P.H., 2011, Strontium dating of the Waccamaw Formation at Acme, NC, and the Duplin Formation at Tar Heel, NC-A Plio-Pleistocene research progress report [abs]: Geological Society of America Abstracts with Programs, v. 43, no. 2, p. 4, accessed November 12, 2020, at https://gsa.c onfex.com/gsa/2011SE/webprogram/Paper184320.html.

Muhs, D.R., Wehmiller, J.F., Simmons, K.R., and York, L.L., 2003, Quaternary sea-level history of the United States, in Gillespie, A.R., Porter, S.C., and Atwater, B.F., eds., The Quaternary period in the United States: Developments in Quaternary Sciences, v. 1, p. 147-183, accessed November 12, 2020, at https://doi.org/10.1016/S15710866(03)01008-X.

Nelson, M., Gray, H., Johnson, J.A., Rittenour, T., Feathers, J., and Mahan, S.A., 2015, User guide for luminescence sampling in archaeological and geological contexts: Advances in Archaeological Practice, v. 3, no. 2, p. 166-177, accessed November 12, 2020, at https://doi.org/10.7183/23263768.3.2.166.

Oaks, R.Q., and DuBar, J.R., eds., 1974a, Post-Miocene stratigraphy, central and southern Atlantic Coastal Plain: Logan, Utah, Utah State University Press, 275 p.

Oaks, R.Q., and DuBar, J.R., 1974b, Tentative correlation of post-Miocene units, central and southern Atlantic Coastal Plain, in Oaks, R.Q., and DuBar, J.R., eds., Post-Miocene stratigraphy, central and southern Atlantic Coastal Plain: Logan, Utah, Utah State University Press, p. 232-245.
Owens, J.P., 1990, Geologic map of the Cape Fear region, Florence 1 degree by 2 degrees Quadrangle and northern half of the Georgetown 1 degree by 2 degrees Quadrangle, North Carolina and South Carolina: U.S. Geological Survey Investigations Series Map, I-1948-A, 1:250,000 scale, accessed November 12, 2020, at https://ngmdb.usgs.gov/ Prodesc/proddesc_10026.htm.

Owens, J.P., and Denny, C.S., 1979, Upper Cenozoic deposits of the central Delmarva Peninsula, Maryland and Delaware: U.S. Geological Survey Professional Paper 1067-A, 28 p., accessed November 12, 2020, at http://pubs.er.usgs.gov/ publication/pp1067A.

Pavich, M.J., Brown, L., Harden, J., Klein, J., and Middleton, R., 1986, ${ }^{10}$ Be distribution in soils from Merced River terraces, California: Geochimica et Cosmochimica Acta, v. 50 , no. 8 , p. 1727-1735, accessed November 12, 2020, at https://doi.org/10.1130/0091-7613(1985)13\%3C39:BAOA QW\%3E2.0.CO;2.

Pavich, M.J., Brown, L., Valette-Silver, J.N., Klein, J., and Middleton, R., 1985, ${ }^{10}$ Be analysis of a Quaternary weathering profile in the Virginia Piedmont: Geology, v. 13, no. 1, p. 39-41, accessed November 12, 2020, at https://doi.org/ 10.1130/0091-7613(1985)13<39:BAOAQW>2.0.CO;2.

Pavich, M.J., Markewich, H.W., and Brook, G.A., 2006, Significance of Kent Island Formation to geomorphic history of the mid-Atlantic region [abs]: Geological Society of America Abstracts with Programs, v. 38, no. 7, p. 226, accessed November 12, 2020, at https://gsa.confex.com/gsa/ 2006AM/webprogram/Paper112865.html.

Pavich, M.J., and Vidic, N., 1993, Application of paleomagnetic and ${ }^{10} \mathrm{Be}$ analyses to chronostratigraphy of alpine glacio-fluvial terraces, Sava River Valley, Slovenia, in Swart, P., ed., Climate change in continental isotopic records: American Geophysical Union Geophysical Monograph, v. 78, p. 263-275, accessed November 12, 2020, at https://agupubs.onlinelibrary.wiley.com/doi/book/ 10.1029/GM078.

Pirkle, F.L., and Czel, L.J., 1983, Marine fossils from region of Trail Ridge, a Georgia-Florida landform: Southeastern Geology, v. 24, no. 1, p. 31-38.

Pirkle, F.L., Pirkle, E.C., and Reynolds, J.G., 1991, Heavy mineral deposits of the southeastern Atlantic Coastal Plain, in Pickering, S.J., ed., Proceedings of the symposium on the economic geology of the southeastern industrial minerals: Georgia Department of Natural Resources, Environmental Protection Division, Georgia Geological Survey, Bulletin 120, accessed November 12, 2020, at https://epd.ge orgia.gov/outreach/publications/georgia-geologic-surveybulletins. 
Poirier, R.K., Cronin, T.M., Ghaleb, B., Portell, R., HillaireMarcel, C., Wehmiller, J.F., Thompson, W.G., Oches, E.A., Willard, D.A., and Katz, M.E., 2015, Quaternary sea level high-stand deposits of the southeast U.S. Atlantic Coastal Plain-Age, distribution, \& implications [abs]: American Geophysical Union, Fall Meeting 2015, abstract \#PP43C-2287, accessed November 12, 2020, at https://ui .adsabs.harvard.edu/abs/2015AGUFMPP43C2287P/ abstract.

Poirier, R.K., Cronin, T.M., Katz, M.E., Browning, J.V., Miller, K.G., and Willard, D.A., 2014, Quaternary sea level history from the Atlantic Coastal Plain-MIS 5 variability [abs]: American Geophysical Union, Fall Meeting 2014, abstract \#PP33C-1260, accessed November 12, 2020, at https://ui.adsabs.harvard.edu/abs/ 2014AGUFMPP33C1260P/abstract.

Poirier, R.K., Cronin, T.M., Katz, M.E., Willard, D.A., Schaller, M.F., Miller, K.G., Browning, J.V., and Wehmiller, J.F., 2016, Late Quaternary sea-level highstands of the mid-Atlantic US coastal plain and sub-orbital variability with implications for ice sheet sensitivity [abs]: Geological Society of America Abstracts with Programs, v. 48, no. 7, p., accessed November 12, 2020, at https://gsa.confex.com/ gsa/2016AM/webprogram/Paper281640.html.

Pooser, W.K., 1965, Biostratigraphy of Cenozoic ostracoda from South Carolina: University of Kansas Paleontological Contributions, Arthropoda, article 8, p. 1-80, accessed November 12, 2020, at https://kuscholarworks.ku.edu/ handle/1808/3812.

Prescott, J.R., and Hutton, J.T., 1994, Cosmic ray contributions to dose rates for luminescence and ESR datingLarge depths and long-term time variations: Radiation Measurements, v. 23, no. 2-3, p. 497-500, accessed November 12, 2020, at https://doi.org/10.1016/13504487(94)90086-8.

Preusser, F., Chithambo, M.L., Gotte, T., Martini, M., Ramseyer, K., Sendezera, E., Susino, G., and Wintle, A.G., 2009, Quartz as a natural luminescence dosimeter: EarthScience Reviews, v. 97, no. 1-4, p. 184-214, accessed November 12, 2020, at https://doi.org/10.1016/j.earscirev.2 009.09.006.

Railsback, L.B., Gibbard, P.L., Head, M.J., Voarintsoa, N.R.G., and Toucanne, S., 2015, An optimized scheme of lettered marine isotope substages for the last 1.0 million years, and the climatostratigraphic nature of isotope stages and substages: Quaternary Science Reviews, v. 111, p. 94-106, accessed November 12, 2020, at https://doi.org/ 10.1016/j.quascirev.2015.01.012.
Rhodes, E.J., 2011, Optically stimulated luminescence dating of sediments over the past 200,000 years: Annual Review of Earth and Planetary Sciences, v. 39, no. 1, p. 461-488, accessed November 12, 2020. https://doi.org/10.1146/ annurev-earth-040610-133425.

Rich, F.J., and Pirkle, F.L., 1993, Palynology and paleoecology of Reids Bluff, in Farrell, K.M., Hoffman, C.W., and Henry, V.J., Jr., eds., Geomorphology and facies relationships of Quaternary barrier island complexes near St. Marys, Georgia: 28th Annual Field Trip, Georgia Geological Society, Georgia Geological Society Guidebooks, v. 13, no. 1, p. $74-81$.

Rovere, A., Hearty, P.J., Austermann, J., Mitrovica, J.X., Gale, J., Moucha, R., Forte, A.M., and Raymo, M.E., 2015, Mid-Pliocene shorelines of the US Atlantic Coastal Plain-An improved elevation database with comparison to Earth model predictions: Earth-Science Reviews, v. 145, p. 117-131, accessed November 12, 2020, at https://doi.org/ 10.1016/j.earscirev.2015.02.007.

Rovere, A., Raymo, M.E., Mitrovica, J.X., Hearty, P.J., O'Leary, M.J., and Inglis, J.D., 2014, The mid-Pliocene sea level conundrum - Glacial isostasy, eustasy and dynamic topography: Earth and Planetary Science Letters, v. 387, p. 27-33, accessed November 12, 2020, at https://doi.org/ 10.1016/j.eps1.2013.10.030.

Rowley, D.B., Forte, A.M., Moucha, R., Mitrovica, J.X., Simmons, N.A., and Grand, S.P., 2013, Dynamic topography change of the eastern United States since 3 million years ago: Science, v. 340, no. 6140, p. 1560-1563, accessed November 12, 2020, at https://doi.org/10.1126/ science. 1229180.

South Carolina LiDAR Consortium, 2007, LiDAR and related data products, Jasper County, South Carolina: South Carolina Department of Natural resources web page, accessed November 24, 2020, at https://www.dnr.sc.gov/ GIS/lidar.html.

Swezey, C.S., Schultz, A.P., Alemán-González, W., Bernhardt, C.E., Doar, W.R., III, Garrity, C.P., Mahan, S.A., and McGeehin, J.P., 2013, Quaternary eolian dunes in the Savannah River valley, Jasper County, South Carolina, USA: Quaternary Research, v. 80, no. 2, p. 250-264, accessed November 12, 2020, at https://doi.org/10.1016/ j.yqres.2013.06.007.

Swezey, C.S., Schultz, A.P., Doar, W.R., III, Garrity, C.P., Bernhardt, C.E., Crider, E.A., Edwards, L.E., and McGeehin, J.P., 2019, Geology of the Hardeeville NW Quadrangle and parts of the Brighton and Pineland Quadrangles, Jasper County, South Carolina: U.S. Geological Survey Scientific Investigations Map 3424, 2 sheets, 1:24,000 scale, accessed November 12, 2020, at https://pubs.er.usgs.gov/ publication/sim3424. 
Swezey, C.S., Seefelt, E.L., and Parker, M., 2018, A brief geological history of Cockspur Island at Fort Pulaski National Monument, Chatham County, Georgia: U.S. Geological Survey Fact Sheet 2018-3011, 4 p., accessed November 12, 2020, at http://pubs.er.usgs.gov/publication/fs20183011.

Szabo, B.J., 1985, Uranium-series dating of fossil corals from marine sediments of southeastern United States Atlantic Coastal Plain: Geological Society of America Bulletin, v. 96 , no. 3, p. 398-406, accessed November 12, 2020, at https://doi.org/10.1130/0016-7606(1985)96\%3C398:UDOF CF\%3E2.0.CO;2.

Taggart, J.E., Jr., Lindsay, J.R., Scott, B.A., Vivit, D.V., Bartel, A.J., and Stewart, K.C., 1987, Analysis of geologic materials by wavelength-dispersive X-ray fluorescence spectrometry, in Baedecker, P.A., ed., Methods for geochemical analysis: U.S. Geological Survey Bulletin 1770, p. E1-E19, accessed November 12, 2020, at https://pubs.er.usgs.gov/ publication/b1770.

Thomas, D.H., 2008, Native American landscapes of St. Catherines Island, Georgia: Anthropo-logical Papers of the American Museum of Natural History 88, parts I-III, 1136 p., accessed November 12, 2020, at http://digitallibrary .amnh.org/handle/2246/5955.

Turck, J.A., and Alexander, C.R., 2013, Coastal landscapes and their relationship to human settlement on the Georgia coast, in Thompson, V.D., and Thomas, D.H., eds., Life among the Tides-Recent archaeology along the Georgia Bight: Proceedings of the Sixth Caldwell Conference, St. Catherines Island, Georgia, May 20-22, 2011, Anthropological Papers of the American Museum of Natural History 98, p. 169-189, accessed November 12, 2020, at http://digitallibrary.amnh.org/handle/2246/6435.

Veatch, J.O., and Stephenson, L.W., 1911, Preliminary report on the geology of the Coastal Plain of Georgia: Georgia Geological Survey Bulletin 26, p. 362-440, accessed November 12, 2020, at https://epd.georgia.gov/sites/ epd.georgia.gov/files/related_files/site_page/B-26.pdf.

Weems, R.E., and Edwards, L.E., 2001, Geology of Oligocene, Miocene, and younger deposits in the coastal area of Georgia: Georgia Geologic Survey Bulletin 131, 124 p, accessed November 12, 2020, at https://epd.ge orgia.gov/document/publication/b-131-geology-oligocenemiocene-and-younger-deposits-coastal-area-georgia-2001/ download.
Weems, R.E., Lemon, E.M., Jr., and Nelson, M.S., 1997, Geology of the Pringletown, Ridgeville, Summerville, and Summerville Northwest 7.5-minute quadrangles, Berkeley, Charleston, and Dorchester Counties, South Carolina: U.S. Geological Survey Miscellaneous Investigations Map, I-2502, 1:24,000 scale, accessed November 12, 2020, at https://pubs.er.usgs.gov/publication/i2502.

Wehmiller, J.F., Belknap, D.F., Boutin, B.S., Mirecki, J.E., Rahaim, S.D., and York, L.L., 1988, A review of the aminostratigraphy of Quaternary mollusks from United States Atlantic Coastal Plain sites, in Easterbrook, D.L., ed., Dating Quaternary sediments: Geological Society of America Special Paper 227, p. 69-110, accessed November 12, 2020, at https://doi.org/10.1130/SPE227-p69.

Wehmiller, J.F., Simmons, K.R., Cheng, H., Edwards, R.L., Martin-McNaughton, J., York, L.L., Krantz, D.E., and Shen, C.-C., 2004, Uranium series coral ages from the US Atlantic Coastal Plain-The "80 ka problem" revisited: Quaternary International, v. 120 , no. 1, p. 3-14, accessed November 12, 2020, at https://doi.org/10.1016/j.quaint.2004.01.002.

Wehmiller, J.F., Simmons, K., Ludwig, K.R., Markewich, H.W., Rich, F., and Hulbert, R.C., Jr., 1997, US Atlantic coastal plain late Quaternary geochronology-TIMS U-series dates continue to indicate $80 \mathrm{kyr}$ sea level at or above present [abs]: Geological Society of America Abstracts with Programs, v. 29, no. 6, p. 346.

Wehmiller, J.F., Thieler, E.R., Miller, D., Pellerito, V., Keeney, V.B., Riggs, S.R., Culver, S., Mallinson, D., Farrell, K.M., York, L.L., Pierson, J., and Parham, P.R., 2010, Aminostratigraphy of surface and subsurface Quaternary sediments, North Carolina coastal plain, USA: Quaternary Geochronology, v. 5, no. 4, p. 459-492, accessed November 12, 2020, at https://doi.org/10.1016/ j.quageo.2009.10.005.

Winker, C.D., and Howard, J.D., 1977, Correlation of tectonically deformed shorelines on the southern Atlantic Coastal Plain: Geology, v. 5, no. 2, p. 123-127, accessed November 12, 2020, at https://doi.org/10.1130/00917613(1977)5\%3C123:COTDSO\%3E2.0.CO;2.

Woolsey, J.R., Jr., 1976, Neogene stratigraphy of the Georgia coast and inner continental shelf: Athens, Georgia, University of Georgia, Ph.D. dissertation, 222 p. 


\section{Glossary}

The following definitions primarily are from the on line version of the Glossary of Geology (https://glossary.americangeosciences.org/), as well as the version by Bates and Jackson (1987), and the version by Gary and others (1972), The Dictionary of Geological Terms by the American Geological Institute (1962), and references included in those publications. The definitions are written to explain the terms used in this report.

deposit Consolidated or unconsolidated material of any type or from any source that has accumulated by some natural process or agent, including material accumulated by water, wind, ice, volcanoes, and chemical processes. In this report, the term deposit refers to a mass (aggregate) or layer of generally unconsolidated sediment that may include gravel, sand, silt, clay, and (or) shell and was laid down (deposited) by water or wind.

estuarine Pertaining to, or formed, or living in an estuary; especially said of deposits and of the sedimentary or biological environment of an estuary. An estuary is a semi-enclosed coastal body of water that has a free connection with the open sea and within which seawater is measurably diluted with freshwater from land drainage.

fluvial (a) Of or pertaining to a river or rivers. (b) Existing, growing, or living in or about a stream or river and its floodplain. (c) Produced by the action of a stream or river.

formation A formation is a lithostratigraphic unit that often contains a variety of related or interlayered rock types and is thick enough and distinctive enough in appearance that it can be mapped at the Earth's surface and (or) in the subsurface. It is defined by characteristics of its included sediments and by stratigraphic position.

marine Of, or belonging to, or caused by the sea. In this report, marine is used as a modifier that identifies the origin of a deposit that commonly contains a variety of sediment types, such as clay, sand, and shell. morphostratigraphic unit A distinct stratigraphic unit, defined by Frye and Willman $(1960$, p. 7) as "a body of rock that is identified primarily from the surface form it displays"; it may or may not be distinctive lithologically from contiguous units, and may or may not transgress time throughout its extent. The term is used in stratigraphic classification of surficial deposits such as glacial moraines, alluvial fans, beach ridges, and other such deposits where landforms serve to give identity to a body of clastic sediments.

progradation The building forward or outward toward the sea of a shoreline or a coastline by nearshore deposition of river-borne sediments or by continuous accumulation of beach material thrown upward by waves or moved by longshore drifting.

sedimentary depositional environment $A$ geomorphic unit in which deposition takes place by physical, biological, and (or) chemical processes. Characteristics of the sediment produced are the result of the intensity and duration of the formative process or processes.

sequence In stratigraphy, a sequence is a succession of sedimentary materials deposited in related environmental conditions that are arranged in chronologic order to show their relative position and age with respect to geologic history as a whole. In this report, the term applies to sedimentary deposits that as a group were deposited during and represent a sea level highstand. The primary use of "sequence" in this report is the same as that in Winker and Howard (1977). These authors differentiated and assigned "informal geographic names" to five regressive geographic shoreline sequences in the southeastern Atlantic Coastal Plain, and "drew" tentative shoreline curves for three of the five sequences. The lines of evidence they used to differentiate the sequences are summarized in the first footnote in this report.

strata (plural of stratum) The term is usually used in its plural form. A distinct sheet-like or tabular layer of homogeneous or gradational, consolidated or unconsolidated, deposited material (a bed or beds) that is (are) separable from layers above and below by a discrete change in the character of the material. 


\section{Appendix 1. Methods Used for Sampling and Analyses}

Previously unpublished data presented in this report are from field investigations that took place from the middle 1990s through 2015. Field methods included sampling ephemeral excavations (for example, large commercial borrow pits, swimming pools, farm ponds, soil pits); exposures along rivers, roads, and railroads; cores; and borings. Optically stimulated luminescence (OSL) and meteoric Beryllium-10 paleosol residence time ( $\left.{ }^{10} \mathrm{BePRT}\right)$ analyses were the primary methods used (individually or in combination) to calculate minimum deposit age (tables 4-7). Standard pedologic nomenclature is used for the generalized soil descriptions that accompany the geologic description for each exposure, core, or boring (figs. 4-7). Some soils developed in the emergent near-shore marine deposits are at the surface, whereas others have been buried by eolian sand (for example, fig. 5). For the purposes of this report, all soils, at the surface or buried, are referred to as paleosols.

Diagnostic properties of soils (in other words, number of horizons, thickness of solum, thickness of the argillic horizon, clay mass of the argillic horizon, and degree of rubification) were measured and compared. Data from soil field descriptions and from sedimentologic and geochemical analyses were compared with luminescence and radiometric age determinations. Samples taken for particle-size analyses were submitted to the U.S. Geological Survey (USGS) Eastern Geology and Paleoclimate Science Center Sediment Laboratory, Reston, Virginia, or to the U.S. Department of Agriculture National Soil Survey Center laboratory in Lincoln, Nebraska. Samples collected for chemical analysis were submitted to the USGS analytical laboratory in Denver, Colorado (methods in Taggart and others, 1987) or to Activation Laboratories Ltd. (Actlabs), Ancaster, Onatrio, using the 8-REE Assay Package by fusion inductively coupled plasma (ICP) and ICP mass spectrometry (ICP-MS). Samples were submitted to the USGS Luminescence Dating Laboratory for age analysis using OSL techniques, (https://www.usgs.gov/centers/gecsc/ labs/luminescence-dating-laboratory?qt-science_support_ page_related_con=4\#qt-science_support_page_related_con). Luminescence procedures followed those of Nelson and others (2015) and Gray and others (2015). Sediment and soil samples collected for accelerator mass spectrometry (AMS) determination of ${ }^{10} \mathrm{Be}$ concentrations were processed by the University of Vermont Cosmogenic Facility, Burlington, Vermont (http://www.uvm.edu/cosmolab/; methods posted at http://www.uvm.edu/cosmolab/?Page=methods.html\&SM= methods_sub_menu.html). The prepared $\mathrm{BeO}$ samples were analyzed isotopically at the Lawrence Livermore Laboratory, Livermore, California, and at the Scottish Universities Environmental Research Center (SUERC). A more detailed description for each of these methods is included in Markewich and others (2013, section 4).

\section{Brief Description of Analytical Methods}

\section{Optically Stimulated Luminescence (OSL) Analysis}

OSL dating provides an age estimate of the last time minerals, such as quartz and feldspar, were last exposed to sufficient light or heat to reset a prior luminescence signal (Preusser and others, 2009; Rhodes, 2011). Latent luminescence is generated by exposure to natural ionizing radiation (potassium, uranium, thorium, and cosmic rays) and results from the accumulation of electrons within defects of the quartz and feldspar mineral lattices. When stimulated by exposure to light, heat, or high pressure, the latent luminescence is emitted either naturally or within a laboratory setting. If it is within a laboratory setting, this luminescence can be precisely measured to calculate how long it has been since buried sediments were last exposed to sunlight, which occurs when sediments are eroded and (or) transported. OSL techniques were used to date both the emergent shoreline deposits, and where needed, the overlying eolian sand deposits. Readers are referred to Lamothe (2016) for a complete discussion of luminescence dating of coastal deposits and to Markewich and others (2013) for an explanation of the OSL techniques used in this study.

Light-tight tubes were used to take samples for OSL dating. One of two methods was employed. From the cleaned face of a road-cut or river-bank exposure, the tube was pushed horizontally into the eolian sand, or where no exposure was available, a 0.76-meter-deep pit was dug and the tube pushed downward into the sediment. For each method, the tube was carefully dug out of the enclosing sediment and capped to prevent light exposure during sampling.

\section{Meteoric ${ }^{10 B e}$ paleosol Residence-Time (10BePRT) Analysis}

A minimum residence time can be determined from the meteoric ${ }^{10} \mathrm{Be}$ inventory (atoms per square centimeter [atoms $\left./ \mathrm{cm}^{2}\right]$ ) of a paleosol and the underlying weathered parent material. Beryllium-10 is a radioactive isotope $\left(\mathrm{t}_{1 / 2}=1.39 \times 10^{6}\right.$ years [yr]; Korschinek and others, 2010) produced in the atmosphere by cosmic-ray spallation of nitrogen and oxygen nuclei and delivered to Earth's surface by precipitation and dryfall (Graly and others, 2011). The ${ }^{10}$ Be inventory (atoms $/ \mathrm{cm}^{2}$ ) of a subaerially-exposed deposit can be used as a quantitative index of subaerial exposure (exposure age and [or] erosion rate) because it is retained in the soil clay-iron oxyhydroxide complex (Graly and others, 2010). Pavich and others (1985) and Pavich and Vidic (1993) included discussions on the use of ${ }^{10} \mathrm{Be}$ analysis in soil chronosequence 
studies. The determination of minimum exposure age based on the concentration of meteoric ${ }^{10} \mathrm{Be}$ is based on a calculation of the inventory $\left(\mathrm{atoms} / \mathrm{cm}^{2}\right)$ in the solum and a simple model of constant flux of meteoric ${ }^{10} \mathrm{Be}$ to the soil surface during exposure. The inventory is the product of the horizon thickness $(\mathrm{cm})$, the bulk density of the horizon (grams per cubic centimeter $\left.\left[\mathrm{g} / \mathrm{cm}^{3}\right]\right)$ and the ${ }^{10} \mathrm{Be}$ concentration $($ atoms $/ \mathrm{g})$ in each horizon. In the absence of analytical data, we estimate horizon bulk density values for the near-shore marine sediment to be between 1.5 and $1.7 \mathrm{~g} / \mathrm{cm}^{3}$ (Markewich and others, 1986, 2013).

No correction has been made for the inherited concentration of ${ }^{10} \mathrm{Be}$. Because sampling depths were limited to soils and underlying weathered sediments, we cannot directly account for any inherited ${ }^{10} \mathrm{Be}$ at each site; however, at the time of deposition, the marine sand probably had a very low concentration of adsorbed ${ }^{10} \mathrm{Be}$.

The accumulation of ${ }^{10} \mathrm{Be}$ is the result of delivery of the isotope by rainwater at a rate of about $1.3 \times 10^{6} \mathrm{atoms} / \mathrm{cm}^{2} / \mathrm{yr}$ at humid, temperate, mid-latitude sites (Brown and others, 1988; Graly and others, 2010). The trend of increasing concentrations and inventories with time in soil chronosequences elsewhere (Pavich and others, 1986; Pavich and Vidic, 1993) supports the hypothesis that an open soil system exposed to the atmosphere continues to accumulate ${ }^{10} \mathrm{Be}$ until the erosion rate of the soil matches or supersedes the delivery rate of ${ }^{10} \mathrm{Be}$. At $\mathrm{pH}$ greater than $5,{ }^{10} \mathrm{Be}$ is strongly adsorbed on particles, particularly clay-size material (Graly and others, 2010; Bacon and others, 2012). The very high distribution coefficients $\left(\mathrm{Kd}>10^{4}\right)$ for clays and metal oxyhydroxides measured in laboratory experiments corroborate field measurements of little solution transport of ${ }^{10} \mathrm{Be}$ (Brown and others, 1988). During soil genesis and clay accumulation in the argillic horizon, ${ }^{10} \mathrm{Be}$ concentrations increase due to processes of adsorption or precipitation of oxyhydroxides. Using the annual average deposition rate (q) of atoms $/ \mathrm{cm}^{2} / \mathrm{yr}$, soil residence times for different sedimentologic units were calculated using the following equations: (1) $\mathrm{N}=$ Conc $\times \mathrm{tk} \times \mathrm{BD}$, (2) Unit inventory $=\Sigma \mathrm{N}$ (atoms $\left./ \mathrm{cm}^{2}\right)$ from each horizon, and (3) Unit residence time $(\mathrm{t})=-(1 / \lambda) \times \ln (1-\lambda \mathrm{N} / \mathrm{q})$, where $\mathrm{N}=$ horizon inventory $\left(\right.$ atoms $\left./ \mathrm{cm}^{2}\right)$, Conc $=$ concentration $\left(10^{8}\right.$ atoms $\left./ \mathrm{g}\right)$, $\mathrm{tk}=$ horizon thickness $(\mathrm{cm}), \mathrm{BD}=$ bulk density $\left(\mathrm{g} / \mathrm{cm}^{3}\right), \lambda$ is decay constant $\left(5.3 \times(0.1)^{7} / \mathrm{yr}\right), \mathrm{q}=$ deposition rate (atoms/ $\mathrm{cm}^{2} / \mathrm{yr}$ ), and $\mathrm{t}$ is in years (yr). The largest uncertainty in residence-time calculations is the variation of the deposition rate. Graly and others (2011) demonstrated that ${ }^{10} \mathrm{Be}$ delivery is highly correlated with rainfall and estimated the uncertainty in the delivery term to be \pm 20 percent, which was adopted for residence-time calculations in this report. 
For additional information:

U.S. Geological Survey

Florence Bascom Geoscience Center

12201 Sunrise Valley Drive

Reston, VA 21092

Publishing support provided by the West Trenton and Reston Publishing Service Centers. 
